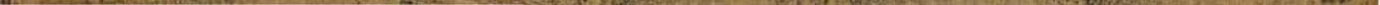





\begin{tabular}{|c|c|c|}
\hline $\left.\begin{array}{l}\text { DTI CoNGress } \\
1 \text { st Session }\end{array}\right\}$ & HOUSE OF REPRESENTATIVES & $\left\{\begin{array}{c}\text { DoCUMENT } \\
\text { No. } 722\end{array}\right.$ \\
\hline
\end{tabular}

Bulletin No. 327

Series $\{$ A, Economic Geology, 105

$\{$ B, Descriptive Geology, 129

DEPARTMENT OF THE INTERIOR

UNITED STATES GEOLOGICAL SURVEY

GEORGE OTIS SMITH, DIRECTOR

\section{GE0LOGIC RECONNAISSANCE}

IN THE

\section{MATANUSKA AND TALKEETNA BASINS ALASKA}

BY

SIDNEY PAIGE AND ADOLPH KNOPF

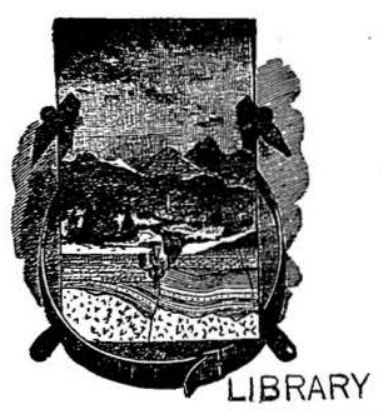

TEXAS TECHNOLOGIGA: LO

LUBEOCK, TEXAS

\section{WASHINGTON}

GOVERNMENT PRINTING OFFICE

1907 



\section{CONTENTS.}

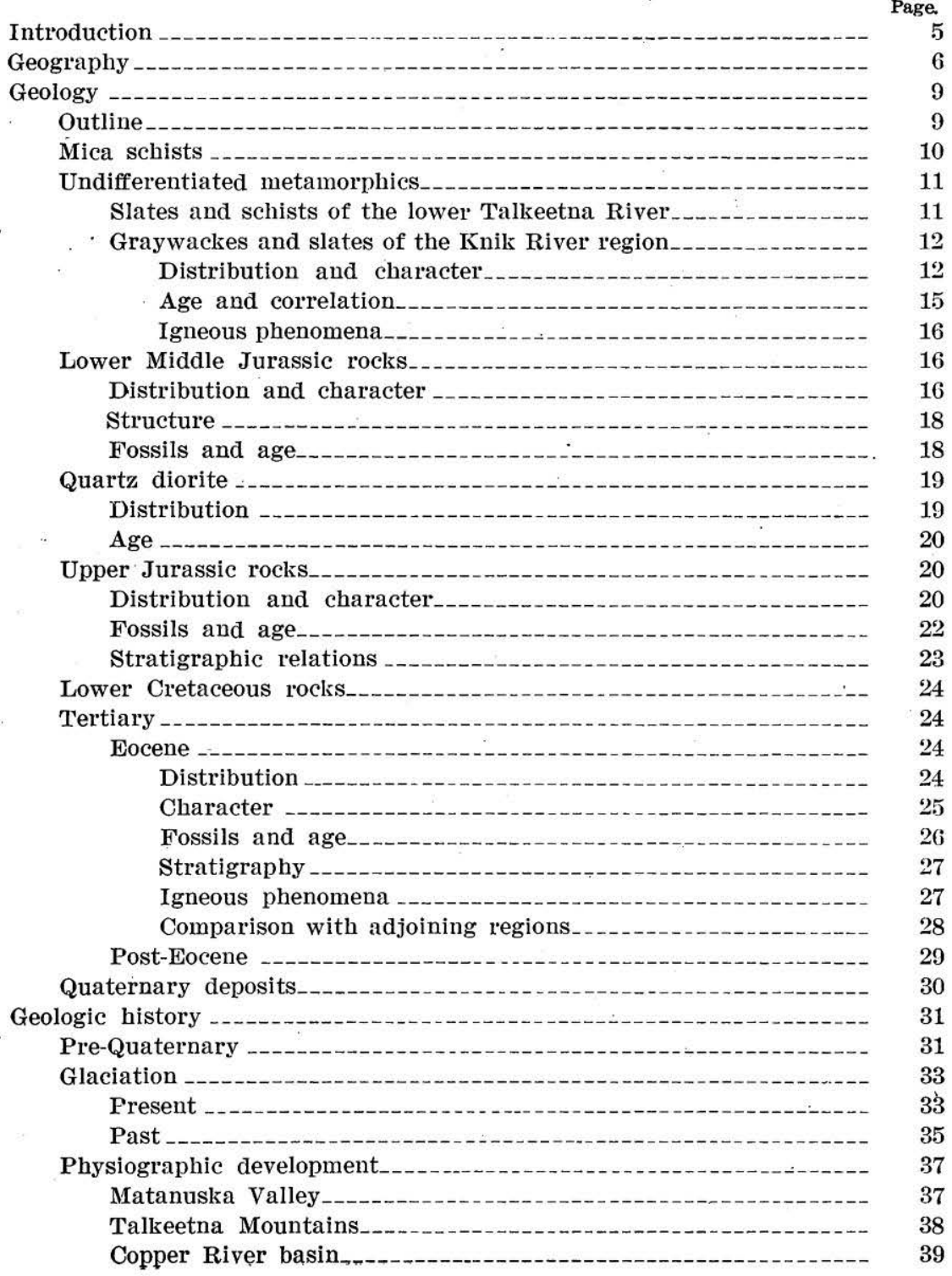


Mineral resources.-1- 40

Coal

Areal distribution

Matanuska field_._-_-_-_. 41

Extent

Structure -

Description of the coal_-_-_-_- 42

Eastern district_-_._- 42

Western district_-_._- 49

Anthracite Ridge field

Geology -..- 52

Description of the coal_-_. 54

Northeastern field

Adjacent coal fields_-_- 57

Analyses and tests_-_-

Chemical and calorimetric tests_-_-_- 59

Coking qualities.---

Mining conditions

Gold -

Distribution of gold-bearing rocks__-_- 64

Description of localities_-_- 65

Willow Creek

Nelchina River-1-_- 67

Knik River-_-_-_-_. 67

Copper

Knik River-_-_. 67

Kashwitna River_-_-_-__- 68

Index _-_- 69

\section{ILLUSTRATIONS.}

PLATE I. Topographic map of Matanuska and Talkeetna basins_-_-_-- (pocket)

II. Geologic map of Matanuska and Talkeetna basins___-_._-_. (pocket)

III. $A$, Conglomerate Mountain, between Tsadaka and Eska creeks; $B$, Stratified breccias and tuffs east of Chickaloon Creek ; $C$, Vertical-walled canyons in conglomerate on Chickaloon Creek; $D$, Intercalated breccias and flows east of Chickaloon Creek-

IV. $A$, Lake in fault block, Conglomerate Mountain; $B$, Limestone at headwaters of Billy Creek; $C$, Rugged topography due to alpine glaciation; $D$, Recession of tributary from trunk glacier ---_-_-

Fig. 1. Section across Matanuska River at Conglomerate Mountain

2. Sketch showing location of Chickaloon tunnels_-_._-

3. Section showing relation of anthracite to intrusive diabase near Purinton Creek

4. Section on Blly Creek 


\title{
GEOLOGIC RECONNAISSANCE IN THE MATANUSKA AND TALKEETNA BASINS, ALASKA.
}

\author{
By Sidney Paige and Adolph Knopf.
}

\section{INTRODUCTION.}

The following report treats of the general geography, geology, and mineral resources of an approximately quadrangular area lying immediately northeast of the head of Cook Inlet. The region includes principally the Talkeetna Mountains and the Matanuska Valley, which separates these mountains from the Chugach Range on the south (Pl. I, pocket). The data for this report were gathered by the writers while they were attached to topographic parties engaged in mapping this region during the summer of 1906. The territory represented by the accompanying map embraces about 7,000 square miles. Necessarily much of the geology of so large an area must be generalized from the observations actually gathered along the line of travel.

The principal resource of the region thus far developed is coal. As a portion of this coal is of high grade, comparing favorably with Pennsylvania bituminous coal, and, as anthracite of good quality also occurs in the region, the investigation of 1906 was directed to determining the boundaries of the various coal fields and to differentiating the ages of the various coal horizons. Attention was also paid to such metalliferous deposits as were encountered. A summary of the results has already been published in the progress report ${ }^{a}$ for 1906.

The region considered was explored by the army expeditions of 1898. Portions of it have been investigated by members of the United States Geological Survey: Mendenhall ${ }^{b}$ explored Matanuska Valley in 1898; Eldridge ${ }^{o}$ explored Susitna Valley in the same year;

a Paige, S., and Knopf, A., Reconnaissance in the Matanuska and Talkeetna basins, with notes on the placers of the adjacent region: Bull U. S. Geol. Survey No. 314, 1907, pp. 104-125.

${ }^{b}$ Mendenhall, W. C., A reconnaissance from Resurrection Bay to Tanana River, Alaska, in 1898: Twentieth Ann. Rept. U. S. Geol. Survey, pt. 7, 1900, pp. 265-340.

' Eldridge, G. H., A reconnaissance in the Susitna basin and adjacent territory, Alaska, in 1898 : Twentieth Ann. Rept. U. S. Geol. Survey, pt. 7, 1900, pp. 7-29. 
and Martin ${ }^{a}$ made a reconnaissance of the Matanuska coal field in 1905. In the preparation of the following report, the work of these earlier investigators has been drawn on, especially that of Martin, who examined the coal resources of the lower Matanuska basin.

The field work of the season of 1906 was in charge of T. G. Gerdine, topographer, as chief of party. Landing was made at Knik, the head of steam navigation on Knik Arm of Cook Inlet, on May 29. Work was begun there on June 1. During June the region on the south side of Knik Arm was mapped; T. G. Gerdine, accompanied by Adolph Knopf as geologist, ascended Knik River to Knik Glacier, and R. H. Sargent, assistant topographer, accompanied by Sidney Paige as geologist, covered the territory south of old Knik. At the end of June Mr. Gerdine, with Mr. Knopf as geologist and a total party of 6 men and 8 horses, started for the interior by way of Matanuska Valley, Hicks Creek, Divide Creek, Caribou Creek, Billy Creek, and Nelchina River. The party returned to Knik by skirting along the western edge of Copper River basin and traveling down Matanuska Valley, arriving at Knik August 31. No great difficulties were encountered, although topographic work was often seriously hampered by rain.

In the meantime R. H. Sargent, with Sidney Paige as geologist and a total party of 6 men and 8 horses, made the circuit through the interior of the Talkeetna Mountains, by way of Chickaloon Creek and Talkeetna River, and returned to Knik along the western flank of these mountains. Some trouble was encountered in fording the numerous streams, which were swollen from continuous heavy rains. During the later part of September the topographers ran a traverse of the eastern shore of Cook Inlet from Point Possession to the mouth of Kasilof River. Tustumena Lake and Kasilof River were also traversed by Mr. Gerdine. Work was closed at Seldovia on September 27 . The geologists of the party had meanwhile started overland to Seward on Resurrection Bay. They visited the placer districts of the Turnagain Arm region en route and arrived at Seward September 27 .

\section{GEOGRAPHY.}

The Talkeetna Mountains occupy the larger part of the region dealt with in this report (Pl. I, pocket). They form an approximately circular mountain mass, bounded on the west and north by the wide valley of Susitna River, on the east by the Copper River basin, and on the south by Matanuska Valley. In general the Talkeetna Mountains merge gradually into the surrounding lowlands; except on the south, where they rise abruptly from the deep depres-

a Martin, G. C., A reconnaissance of the Matanuska coal field, Alaska, in 1905: Bull. U. S. Geol. Survey No. 289, 1906. 
sion of Matanuska Valley. The interior of this mountain mass is an exceedingly rugged area, and access to it is possible only along the larger stream systems. Few of the peaks exceed 5,000 to 6,000 feet in altitude, but in the central portion some of the highest points reach altitudes of 8,000 to 9,000 feet.

The drainage of the Talkeetna area is rudely radial. The larger portion of it is tributary to Susitna River. In the southeastern portion of the area the headwaters of Susitna, Copper, and Matanuska rivers form a closely interlocking network of streams.

The Susitna is the largest river of the region. This great stream, which has a width of 2 miles near its mouth, rises in the northwestern part of the Copper River basin, and, after flowing westward around the northern flank of the Talkeetna Mountains, turns southward and empties into the northern end of Cook Inlet. The most important eastern tributary of the Susitna in the region under discussion is Talkeetna River, which heads at an altitude of about 5,000 feet in the heart of the Talkeetna Mountains. It flows northwestward for about half its length, then turns abruptly to the southwest and continues to Susitna River, which it enters about 85 miles above its mouth. The Talkeetna is about 75 miles long. Near its mouth it is a swift stream, 300 or 400 feet wide. During high water it can be crossed with a pack train only by swimming the horses and rafting the outfit. Sheep Creek is a tributary of Talkeetna River 14 miles above its mouth. It flows more slowly than the river and is, because of its depth, difficult to cross, so that rafting is necessary.

A considerable number of large streams, which, however, are smaller than the Talkeetna, drain the western flank of the Talkeetna Mountains and empty into Susitna River. They are, in order from north to south, Sunshine Creek, Montana Creek, Kashwitna River, Little Willow Creek, and Willow Creek. Little Susitna River, which is the next stream south of Willow Creek, belongs to the drainage basin of Matanuska River, but empties directly into Cook Inlet.

East of the Talkeetna Mountains lies the broad expanse of the Copper River basin, extending to the Wrangell Mountains on the east and bounded by the Alaska Range on the north and the Chugach Mountains on the south. The surface relief of this area is slight and is produced mainly by long, low gravel ridges. Innumerable ponds and lakes are the most striking features of the landscape. The southwestern portion of the basin is drained by Matanuska River, which, with its headwater tributaries, has cut gorges 300 to 400 feet deep in the underlying gravel deposits.

Matanuska Valley, which lies between the Talkeetna and Chugach mountains, opens out at its head and merges into the flats of the Copper River basin. In its upper course it is about 1 mile wide, but 
it gradually widens downstream to 5 to 10 miles, and below Tsadaka Creek flares out to a width of 20 miles. In minor details the floor of the valley is decidedly irregular in relief, consisting of a succession of undulating low ridges and knolls with interspersed kettles.

Matanuska River, the second largest.stream of the region, drains into the eastern end of Knik Arm, instead of into Cook Inlet proper. It heads directly against Tazlina River, of the Copper River drainage, from which it is separated by a low, almost imperceptible divide, having an altitude of 3,000 feet. The general course of the Matanuska is $\mathrm{S} .70^{\circ} \mathrm{W}$., and its length is about 100 miles. The river flows in a trough or valley sunk into the floor of the broader valley previously described. The newer valley is a mile or two wide along the lower stretches of the stream, but in places closes to. a narrow box canyon 300 or 400 feet deep. The Matanuska is a swiftly flowing, silt-laden stream, with a current reaching probably 7 miles an hour. The volume of water varies with the season and is highest in June. The average width of the river is about 400 feet.

Caribou, Hicks, Chickaloon, Kings, Granite, Eska, and Tsadaka creeks are the principal streams entering Matanuska River from the north. Caribou Creek, the largest of these streams, drains a considerable area in the Talkeetna Mountains. Chickaloon Creek has a length of about 30 miles. A pass at its head, over which a pack train can easily be taken, connects its valley with that of the Talkeetna. The two valleys thus form a highway through the heart of the Talkeetna Mountains. A large number of streams enter the Matanuska from the south, draining the north flank of the Chugach Mountains, but none attain large size.

Near the head of Knik Arm, uniting irregularly with the various tidal sloughs, the Matanuska is joined by Knik River from the southeast. Knik River heads in Knik Glacier, and its length is only about 25 miles. Several small tributaries enter the Knik from both sides, the largest and most important of which is Metal Creek, emptying into the river from the east near the front of the glacier. Knik Valley is 3 to 4 miles wide, perfectly flat, and covered with gravel, through which protrude occasional hummocks of bed rock. Its course is remarkably straight throughout its entire length and it is walled in by mountains which rise steeply from the valley floor. Knik River possesses no single well-defined channel, but spreads out over its gravel plain in a number of branches, whose positions are likely to vary from year to year. Boats can be towed up the river by hand, although with some difficulty on account of bars and quicksands, to within 5 miles of the glacier.

The rugged group of mountains lying on the south side of Matanuska Valley is a portion of the Chugach Mountains. As seen from Matanuska Valley, they include numerous peaks 7,000 to 10,000 feet 
high and present a very inaccessible and forbidding aspect. The Chugach Mountains have a general northwesterly trend from Mount St. Elias, and constitute the high barrier between the Pacific coastal belt and the interior. At the head of Knik Arm they swing southward and continue, though with diminished altitudes, into Kenai Peninsula and Kodiak Island.

\section{' GEOLOGY. $a$}

OUTLINE.

The rocks of the area investigated range in character from crystalline schists of probable pre-Silurian age to unconsolidated Quaternary stream and glacial gravels. A great central area of various granitic rocks, of middle Mesozoic age, makes up the mass of the Talkeetna Mountains. (See Pl. II, pocket.) On its southern flank this granite core is in part bounded by a narrow belt of albite and garnetiferous mica schists, which is in turn, on its southern border, bounded by a narrow band of granite similar in type to the central mass.

On its northwestern margin it is bordered by a series of slates and graywacke-slates. The latter series shows some similarity to the great series of graywackes and slates which occur on the south side of Knik Arm and strike into the Chugach Mountains.

East of Chickaloon Creek marine Jurassic strata attain an extensive development. They are divided into two unconformable series. The lower series is characterized by a volume of andesitic breccias, agglomerates, and amygdaloids of greenstone habit, exceeding 1,000 feet in thickness. These volcanics are conformably overlain by several thousand feet of sandstones, shales, and conglomerates. The younger unconformable series of Jurassic rocks consists of shales, sandstones, and conglomerates, with some interstratified tuff and arkose. The age indicated ranges from the late Middle Jurassic through the Upper Jurassic. Conformably overlying these strata is a Lower Cretaceous limestone, 300 feet thick.

- Upper Eocene rocks are represented by the Kenai formation, a series of folded sandstones, shales, arkoses, and conglomerates, carrying thick beds of bituminous coal. These coal beds are limited to the lower basin of Matanuska River.

A series of post-Eocene basaltic lavas and associated pyroclastics overlie the older rocks unconformably. They attain a thickness of 1,000 feet, and form the summit topography of much of the area.

An extensive sheet of glacial gravels is the most recent deposit of the region.

${ }^{a}$ For an abstract of this paper see Bull. Geol. Soc. America, vol. 18, pp 325-332. 
Geologic column of the Talkeetna and Matanuska basins.

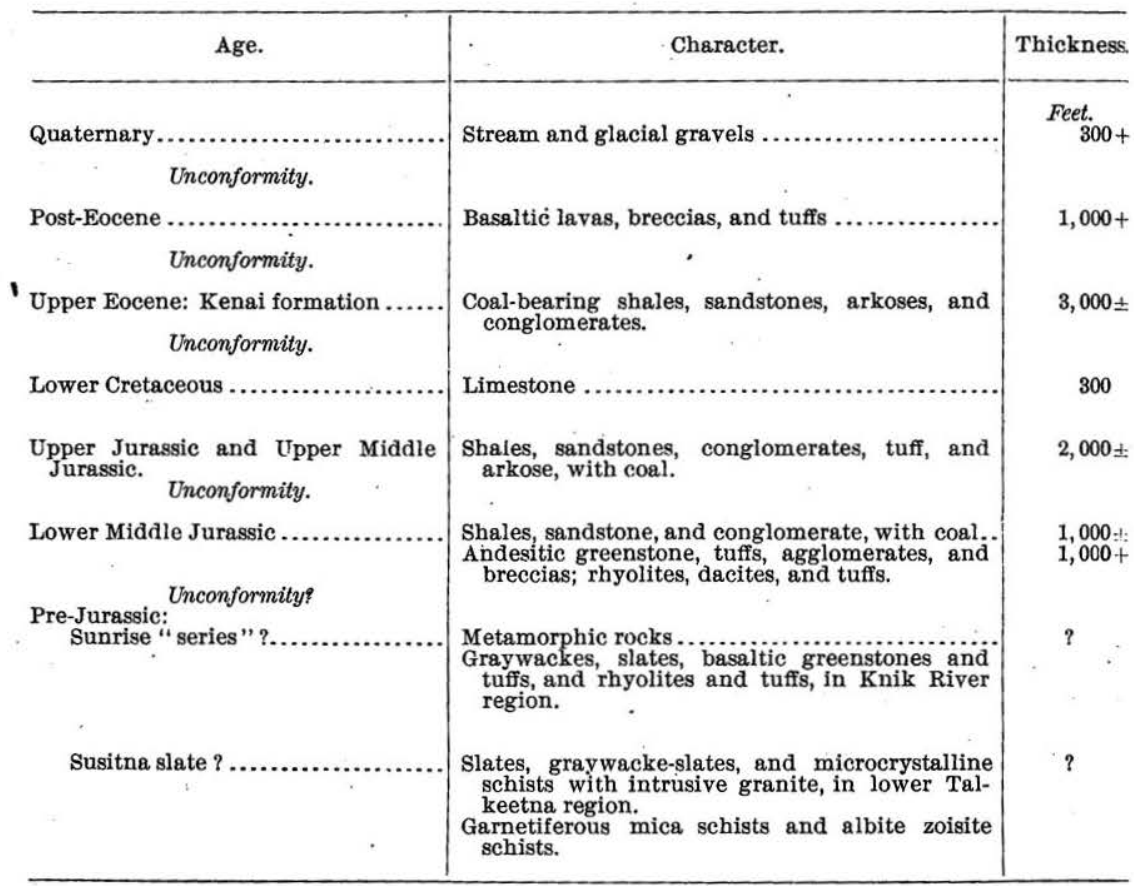

MICA SCHISTS.

A series of mica schists forms a narrow belt, not over 3 miles wide, near the head of Willow Creek. This belt has an east-and-west direction, and is known to extend not farther east than Tsadaka Creek and to disappear westward beneath the gravel floor of Susitna Valley.

The schists are thoroughly foliated rocks of medium grain, and show in general no variations in appearance. Under the microscope they are found to comprise garnetiferous mica schists and chloritealbite schists. The garnetiferous mica schist is composed largely of quartz, which shows powerful strain shadows, muscovite in long laths, chloritized biotite, orthoclase, and garnet altered almost completely to chlorite. In the albite schist soda feldspar is the dominant constituent. The albite poikilitically incloses various other constituents, chief among which is clinozoisite in long, stout prisms, usually oriented parallel to the schistosity. In addition to the albite abundant quartz, crushed and showing strain shadows, is present in considerable amount, with some chlorite and clouds of magnetite dust. Muscovite is but an accidental constituent, and is only found included in the albite plates. Some of the albite schists, however, contain muscovite as an important constituent. Such a schist, ex- 
amined microscopically, shows large albites in the form of augen, quartz badly crushed and strained, muscovite of a sericitic nature, and chlorite, and is evidently a schist affected by a second period of dynamic activity.

Some serpentine and pyroxenite are included in the mica-schist series. The pyroxenite presents a pseudoporphyritic aspect under the microscope, due to crushed plates of monoclinic pyroxene lying embedded in a groundmass of serpentine. The pyroxene is noteworthy on account of the fine multiple twinning parallel to the orthopinacoid and of the slicing which has taken place along that plane. The shearing of the pyroxenite is probably to be correlated with the movement which crushed the schists.

The strike of the schistosity varies from N. $45^{\circ}$ E. to N. $60^{\circ}$ W. The dips average near $40^{\circ}$, but are inclined on both sides of the vertical. Fossils have not been obtained from this formation, nor is their occurrence in it likely. On account of its thoroughly metamorphic character, which considerably exceeds that of any of the terranes presently to be described, this formation is regarded as representing the oldest rocks of the region. Its members show a petrographic similarity to the mica schists of the Yukon-Tanana region, and a possible correlation with the pre-Silurian of that district is suggested.

\section{UNDIFFERENTIATED METAMORPHICS.}

Metamorphic rocks, which, because of lack of fossil and other stratigraphic criteria, can not be placed definitely in the stratigraphic column, occur in the lower portion of Talkeetna Valley-in the extreme northwestern part of the region traversed-and in the Knik River region-in the southern portion.

\section{SLATES AND SCHISTS OF THE LOWER TALKEETNA VALLEY.}

A series of metamorphic rocks outcropping along the upper course of Susitna River and the headwaters of the Cantwell was named the Susitna slate by Eldridge, who describes the beds as-

* * * essentially quartzitic, varying in coarseness of material from an extremely fine homogeneous rock to one of granular structure. In addition to quartz there are occasional orthoclase, plagioclase, biotite, muscovite, scattered grains of iron oxide, and minute fragments of slate, apparently of the same nature as the fine-grained slates of the series itself. The entire series has been extensively sheared and the sand grains crushed, so as to produce the partial schistose or slaty structure that so generally prevails. Whitman Cross, of the Survey, who examined the rock microscopically, found no grains referable to igneous rocks, in spite of the impression from megascopical examination that the rocks were sheared eruptives. 
A feature of the formation in localities where great crumpling of the strata has taken place is the presence of large quartz seams, half an inch to 2 feet thick, reticulating the exposed surface of the series with considerable intricacy. Such seams often show mineralization with sulphide of iron. ${ }^{a}$

The work of the season of 1906 showed that a series of rocks similar to the Susitna slate and schist has a considerable areal distribution along the lower course of Talkeetna River. In that region they show somewhat greater petrographic diversity than where studied by Eldridge. With the slates are associated various microcrystalline schists; that is, schists that are so fine-grained that their constituents are not recognizable by the unaided eye. Some are of aphanitic texture and display only a feeble schistosity. Examined microscopically, they prove to be composed largely of light-green hornblende in slender prismatic development. Quartz, chlorite, epidote, and biotite are the remaining constituents. Other schists, whose foliation is more apparent to the eye, consist of fine-grained aggregates of quartz and biotite, with much included carbonaceous material. In general the metamorphism of these schists has proceeded far enough to obliterate the evidence of their original clastic origin. In the lower Talkeetna River region they are associated with batholithic masses of granitic rock and locally are intimately intruded by apophyses of such masses. Much of their metamorphism may be imputed to this relation. The Susitna rocks have yielded no fossils nor are their stratigraphic relations known, so that their age must remain conjectural. The unmetamorphosed character of the Jurassic shales and sandstones of the Talkeetna Mountains indicates that the Susitna rocks are probably pre-Jurassic. The Susitna slates and schists show some lithologic resemblance to the rocks of the Sunrise "series" of the Turnagain Arm region, but appear for the most part to be somewhat more highly metamorphosed.

The microcrystalline schists are interstratified with the clay slates and, especially those containing notable amounts of hornblende, appear to represent metamorphosed bands of impure dolomites. Similar rocks are not known from the Sunrise "series." On account of these differences, which on the whole appear to outweigh the similarities, the Susitna slate is placed beneath the Sunrise formation in the geologic column.

GRAYWACKES AND SLATES OF THE KNIK RIVER REGION.

DISTRIBUTION AND CHARACTER.

The rocks on the south side of Knik Arm and in the valley of Knik River consist largely of graywackes, slates, and phyllites, with

a Eldridge, G. H., Reconnaissance in Susitna basin and adjacent territory, Alaska, in 1898: Twentieth Ann. Rept. U. S. Geol. Survey, pt. 7, 1900, p. 15. 
some greenstones, rhyolites, and tuffs. The general strike of the series $\left(\mathrm{N} .60^{\circ} \mathrm{E}\right.$.) tends to carry them eastward approximately parallel to the course of Matanuska River. Their distribution to the south is indicated by the fact that the moraine of the great glacier at the head of Knik Valley is composed exclusively of graywacke and slate. As the same rocks are reported by Mendenhall from along the shores at Port Wells on Prince William Sound, it is probable that this section across the Chugach Mountains consists largely of graywackes and slates.

The graywackes are highly indurated rocks, whose most conspicuous feature to the unaided eye is the unusual abundance of small angular slate fragments. They are of dark bluish-gray color and at some places are not easily distinguishable from basic volcanics. Under the microscope the graywackes prove to be of rather heterogeneous derivation. Angular fragments of quartz, containing capillary rutile, fragments of feldspar, plagioclase in part, usually altered and occasionally distinctly rounded, hornblende, augite, and fragments of slate comprise the main constituents. A little muscovite, epidote, pyrite, magnetite, and zircon are present as accessories. The binding material is a feebly polarizing aggregate flecked with chlorite. Other thin sections of the graywackes show, in addition to the slate particles, fragments of quartzite, of micropegmatite, and of a chloritized volcanic, probably an andesite. The graywackes are roughly schistose, and pass by increasing fineness of grain into graywacke slates and into highly cleaved clay slates. The slates locally assume a schistose foliation, become glossy, and pass into phyllites. At Knik Glacier they are affected by slip-strain cleavage, and are acutely crumpled and contorted. The interbedded graywacke, however, has been rendered only roughly schistose. Quartz stringers are very abundant in the slates and graywackes of the Sunrise "series," and at places form an intricate network of small veins, averaging about an inch in thickness. Mineralization of the quartz is not visible to the eye. In the Sunrise district, however, free gold is found at some places in these stringers.

Near the mouth of Knik River a great volume of greenstone tuffs, estimated as probably 1,500 feet thick, was found associated with the graywackes. They are dense, fine-grained rocks of green color, conspicuous on account of the numerous angular fragments of black slate which they inclose. The microscope shows that the rock is largely composed of opaque angular fragments of a greenish-yellow color. In places such fragments contain phenocrysts of highly altered feldspar and porphyritic augite in fine idiomorphic development. The remaining constituents of the tuff comprise fragments of brown hornblende, augite, graywacke, intersertal basalt (much altered), and 
quartz diorite. Chlorite and calcite form a scanty binding material, and a little leucoxene occurs as an accessory mineral.

The massive greenstones found in the Sunrise "series" are, as a rule, nonporphyritic rocks of aphanitic texture. Secondary minerals, such as light-green hornblende, chlorite, and epidote, are strongly developed, and the feldspars are represented by aggregates of decomposition products. The former structure is thus often obscured, but remnants of ophitic or closely allied textures are sufficiently well preserved to leave no doubt as to the original character of the rock.

Rhyolites and their tuffs are associated with slates at a locality half way up Knik River. The acidic volcanics are of felsitic habit and include flow-banded types and porphyritic phases with inconspicuous quartz phenocrysts. A rude schistosity has been impressed on them, and in consequence they show a faint unctuous appearance on their foliation planes. In thin section a strongly marked eutaxitic structure is displayed, which is further emphasized by the fact that certain flow bands show a more advanced devitrification than others. Porphyritic constituents are not numerous. Of these, quartzes are most abundant. They exhibit in places some magmatic corrosion, but are usually broken and dispersed. A few orthoclase phenocrysts are present, crushed and largely converted to sericite. Epidote, replacing original femic phenocrysts, is a rare constituent. The groundmass is microcryptocrystalline and very feebly polarizing. Occasionally certain flow bands are noteworthy on account of the abundance of very minute flakes of sericite.

The tuffs accompanying the rhyolites, like the greenstone tuffs, are remarkable for the abundance of small, angular slate fragments which they include. Microscopic study indicates that the rhyolite tuffs grade into graywackes. A transitional type is represented by a rock in which glassy quartzes and white feldspars are studded in porphyritic fashion in a dense greenish matrix. In thin section about half of the slide is composed of numerous fragments of microcryptocrystalline volcanics showing fluxion phenomena. They are sparingly porphyritic, and in one section were found to contain dihexahedral quartz. These, as it were, constitute a groundmass for angular fragments of quartz and plagioclase. The microclites commonly referred to rutile are unusually well shown in the quartz fragments, as is also a little zircon. The feldspar occasionally shows rounded edges, and is usually in an advanced state of alteration. Some partially chloritized augite and a little hornblende are also present. Slate particles are numerous, and show molding around the other constituents in consequence of the shearing to which the rock has been subjected. Chloritic matter forms the binding material of the rock.

The general petrography of the rocks of the Knik region proves that the graywackes were derived largely from the destruction of a 
granitic area, probably, as the inclusions in the greenstone tuff show, of quartz-diorite character.

The various rock types, graywackes, greenstone tuffs, and rhyolite tuffs are characterized by the presence of numerous small, angular slate fragments. Metamorphism has not proceeded far enough to mask the clastic origin of the typical members, nor to cause a marked development of new minerals.

The cleavage of the rocks of the Sunrise "series" is parallel to the bedding. The strike, which is N. $60^{\circ} \mathrm{E}$. at the mouth of Knik River, gradually swings around to the north as the Knik River is ascended, and becomes N. $10^{\circ} \mathrm{E}$. at Knik Glacier. This change of strike in the strata coincides in a general way with the change in the axial trend of the Chugach Mountains, which in this region make a great bend to the south and continue into the Kenai Peninsula as the Kenai Mountains. The dips are usually high, ranging from $40^{\circ}$ to $90^{\circ}$. Structurally the series presents a monoclinal succession of steeply dipping strata, which is undoubtedly due to repetition by close folding.

\section{AGE AND CORRELATION.}

The rocks on the south side of Knik Arm were included by Mendenhall ${ }^{a}$ in the Sunrise " series," as originally defined-a name given to the metamorphic gold-bearing rocks occurring in the Sunrise mining district on Turnagain Arm. They are described by Moffit ${ }^{b}$ as consisting principally of slates and arkoses, with very subordinate amounts of quartzite and conglomerate. The rocks of the region under discussion bear a general lithologic resemblance to those of the Turnagain Arm region and conform with them in strike. There appears, accordingly, no good reason for introducing a new formation name, and they are here discussed under the designation of Sunrise formation, although basaltic greenstones and aporhyolites have not been described from the type locality. No fossils have yet been found in the Sunrise formation, so that only tentative conclusions as to its age can be drawn. The slates and graywackes of the Sunrise "series" in the region under discussion are more highly metamorphosed than the shales and sandstones in the adjoining Matanuska region. As the latter are shown by their marine fauna to be lower Middle Jurassic, an age probably earlier than Middle Jurassic is indicated for the Sunrise "series." From a similar line of evidence in the Kachemak Bay region Moffit ${ }^{c}$ has assigned the formation to a pre-Jurassic, probably Paleozoic, age.

${ }^{a}$ Op. cit., p. 306.

${ }^{\circ}$ Moffit, F. H., Gold fields of the Turnagain Arm region: Bull, U, S, Geol, Survey NQ. 277, 1906, p. 16.

- Op. cit., p. 19. 
In the absence of definite paleontologic evidence, the correlation of the Sunrise formation with the similar graywacke-slate series of Prince William Sound must be made on purely petrographic and structural grounds. On this basis it appears that the Sunrise formation is probably the equivalent of the Valdez formation.

IGNEOUS PHENOMENA.

In addition to the greenstones, rhyolites, and accompanying pyroclastics, which form an integral portion of these rocks, other igneous rocks occur, probably as intrusives. They include quartz diorite, peridotite (lherzolite), and andesite. The quartz diorites on the south side of Knik Arm form bosses, whose relation to the surrounding sedimentary rocks was not seen. They are cut by andesitic dikes of greenstone habit. A mass of peridotite composed of augite, enstatite, and partially serpentinized olivine occurs in the mountain mass southwest of Eklootna Creek.

LOWER MIDDLE JURASSIC ROCKS.

DISTRIBUTION AND CHARACTER.

The oldest rocks of determined age comprise andesitic greenstones, quartz porphyries, tuffaceous sandstones, shales, and conglomerates. Some coal is found in the nonvolcanic portion of this series. The greenstones constitute the most characteristic member and attain a wide distribution, especially in the interior of the Talkeetna Mountains, where only the volcanic portion of the series appears to be present.

The great bulk of the greenstones are clearly products of explosive volcanic activity. They occur largely in the form of stratified breccias (Pl. III, $B$ ), in which angular fragments of dark-blue porphyritic rock, varying in size from microscopic dimensions to several feet in diameter, are inclosed in a matrix of green color. This contrast of colors, which serves to emphasize the breccia character of the rock, is due to the fact that the matrix is abundantly changed into the green mineral chlorite, whereas the large angular fragments, being of a dense, fine-grained texture, have-often withstood alteration more thoroughly. With the breccias are intercalated various sheets of amygdaloids, porphyries, and flow breccias. (See Pl. III, D.) The amygdaloids are frequently studded with numerous large amygdules, whose filling may consist of chalcedony, quartz, calcite, chlorite, or zeolite.

A prominent feature of the greenstones is the great amount of shattering and slickensiding which they exhibit. Where this internal movement has been of a more regular character a rude schistosity has been impressed on them. Extensive pyritization of a diffused char- 


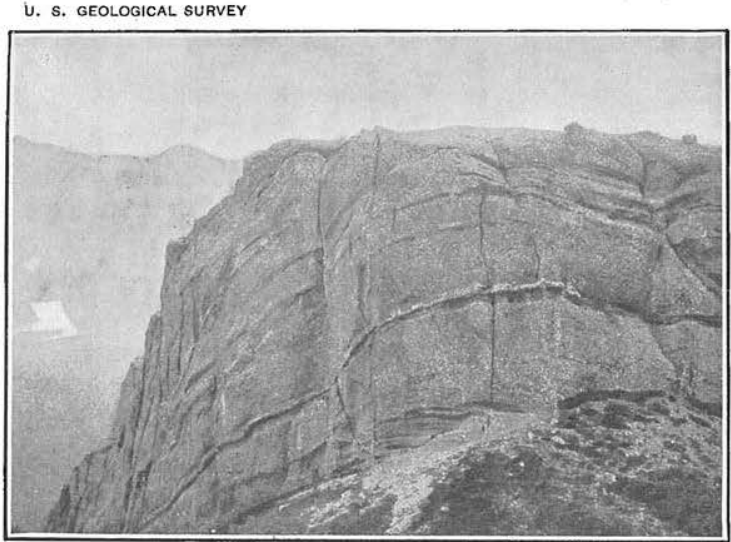

A. CONGLOMERATE MOUNTAIN, BETWEEN MOOSE AND ESKA CREEKS.

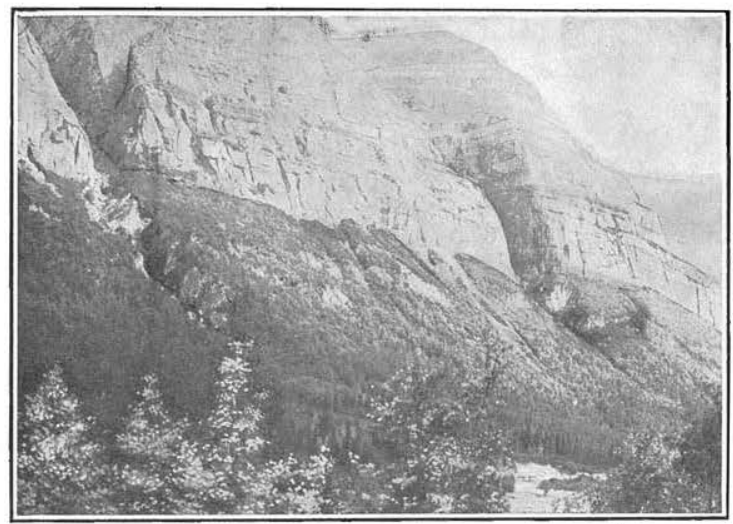

C. VERTICAL-WALLED CANYONS IN CONGLOMERATE, CHICKALOON CREEK.

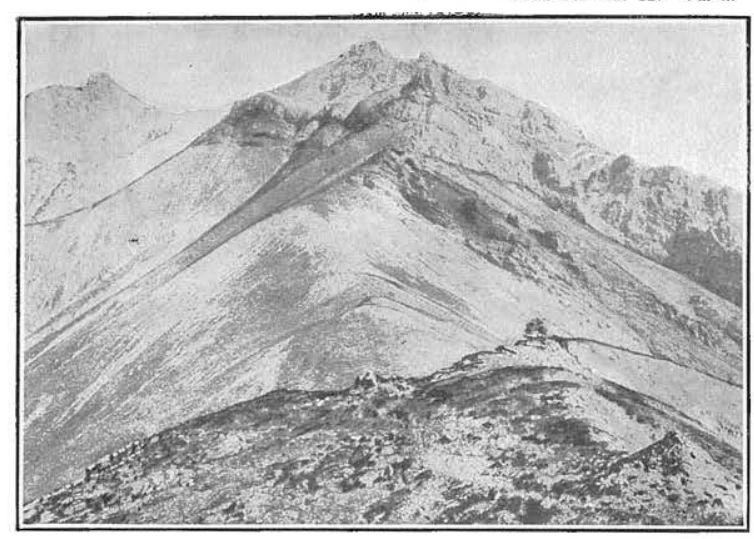

B. STRATIFIED BRECCIAS AND TUFTS EAST OF CHICKALOON CREEK.

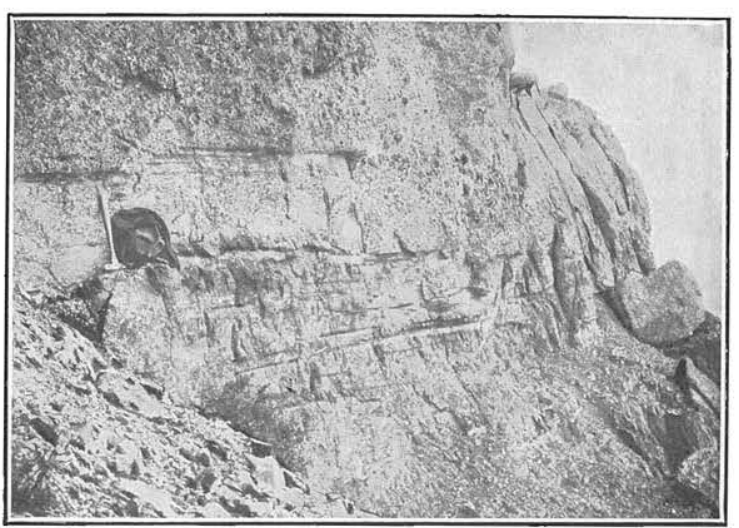

D. INTERCALATED BRECCIAS AND FLOWS EAST OF CHICKALOON CREEK. 

acter was noted at several localities, but a thin irregular seaming with calcite appears to be the most usual form of mineralization.

Petrographically the greenstones are prevailingly andesitic, usually of hyalopilitic or pilotaxitic texture, and more or less completely chloritized. Examples more basic than andesite appear to be rare and were noted only on Boulder Creek, about 7 miles from its mouth, where greenstones displaying columnar structure make up the north wall of the valley. These prove to be diabase porphyries.

The thickness of the greenstones often exceeds 1,000 feet. The tuffs locally contain fragments of lignite, and at the eastern end of Sheep Mountain, in the upper Matanuska Valley, were found to carry marine shells in a fine state of preservation.

Under the convenient field term "quartz porphyry" have been grouped various rhyolites and-dacites, including their tuffs, that are associated with the greenstones. These are'widely distributed in the interior of the Talkeetna Mountains. The rhyolites are generally flinty-looking rocks containing glassy phenocrysts, but also include some splendid flow-banded phases. Devitrification is common in the rhyolites. Some of the dacites resemble the rhyolites in appearance, but others possess a greenstone habit. These acidic lavas appear to have been erupted either during or soon after the period of the andesitic extrusions, as they contain included in them fragments of microlitic andesite.

During the extravasation of the rhyolites conditions were not uniform over the province. While lavas were accumulating in some portions of the region sedimentation was progressing in others. On the divide between Hicks and Boulder creeks a white stratum 20 feet thick is prominent. It proves to be a feldspathic sandstone, with some irregular thin white bands, about a quarter of an inch thick, scattered through it. The microscope shows that these bands are composed of microspherulitic particles and fragments of devitrified rhyolite, with fine flow structure, indicating that showers of rhyolitic material were prevalent during this portion of lower Middle Jurassic sedimentation.

At various points, especially in the region east of Chickaloon, Creek, the greenstones are overlain conformably by a series of sandstones and shales. Some finely flow-banded volcanics, now devitrified, are in places associated with the sediments, proving that eruptive activity had not entirely ceased during their deposition. This series, by its dominantly sedimentary character, can be readily distinguished from the underlying meta-andesite accumulation.

The sandstores are usually feldspathic, and under the microscope show numerous small fragments of microlitic andesite no larger than the feldspar or quartz grains. The shales locally carry numerous 13070-Bull. 327-07-2 
limestone nodules. At various localities the shales and sandstones associated with the greenstones are intensely shattered and crushed. This is especially notable in the gorge of Billy Creek. In this vicinity also occur several conglomerates not found elsewhere in the series. Some of these, perhaps, merit description. The conglomerate just above the head of the gorge is composied of well-rounded bowlders, up to 4 feet in diameter, of andesite porphyry and of amygdaloid. The matrix of this volcanic conglomerate has been severely slickensided. On the same stream another conglomerate 400 feet thick is revealed. It consists of various porphyries and white quartz pebbles embedded in a gritty, coherent matrix. A noteworthy feature of this conglomerate is the abundance of pebbles that show individual faulting.

\section{STRUCTURE.}

The general strike of the series is north and south (magnetic), and the dips. are variable. Along one of the western tributaries of Hicks Creek a gentle synclinal folding is exposed; farther north on Hicks Creek a small steep anticline, trending N. $30^{\circ}$ E. (magnetic), is shown. The beds are broken by numerous faults of small throw and, as is evident from the detailed description of the series, have been subjected to a large amount of internal disturbance. Detailed mapping will show the presence of a complicated system of more extensive faults.

\section{FOSSILS AND AGE.}

The fossils found in tuffs associated with the greenstones were submitted to T. W. Stanton, who reports as follows:

6 A. K. 201. Fossiliferous tuffs, associated with lavas and coarse pyroclastics, from the head of Matanuska River.

Rhynchonella.

Lima.

Pecten. Smooth species.

Pecten. Species of Vola type.

Trigonia.

The Jurassic age of this lot is clearly shown by the form of the Trigonia and of the ammonite (Sonninia?). The general aspect of the fauna is that of the lower part of the Enochkin, though it may be somewhat older than the fauna in lots $88 \mathrm{~A}$ and $88 \mathrm{~B}$. With the exception of the Vola-like species of pecten there is nothing in it to suggest the lower Jurassic fauna of Seldovia.

According to this determination the age of the greenstones is lower Middle Jurassic. ${ }^{a}$

\footnotetext{
a Stanton, T. W., and Martin, G. C., Mesozoic section on Cook Inlet: Bull. Geol. Soc. America, vol. 16, 1905, pp. 391-410.
} 
In general the sandstones and shales are barren of fossils, though belemnites are rather common. The following species, however, were found and were submitted to Mr. Stanton, who reports as follows:

6 A. K. 88A. Caribou Creek, tributary to Matanuska River.

Inoceramus cf. Iucifer Eichwald.

Phylloceras.

Pleuromya.

Pleurotomaria.

Stephanoceras.

Oppelia?

6 A. K. 88B. Same locality as preceding, but found in float bowlder in stream bed.

Inoceramus.

Stephanoceras.

Natica.

Phylloceras.

Sonninia? (two species).

Belemnites.

The two lots are evidently from the same horizon, and nearly all the species occur in the lower part of the Enochkin at Snug Harbor.

The age of these sandstones and shales is, therefore, substantially the same as that of the greenstones-lower Middle Jurassic. The sedimentaries from which the above fossils were collected do not differ much in appearance from the Tertiary sandstones of the region. The greenstones, however, wear a more ancient aspect, and are usually more internally disturbed than the sedimentaries, probably in consequence of the volume changes which they have undergone during their metasomatic alteration.

\section{QUARTZ DIORITE.}

\section{DISTRIBUTION.}

Much of the rugged interior of the Talkeetna Mountains remains unexplored, but such evidence as is available indicates that the great central area consists wholly of granitic rocks. Extensive exposures of granular crystallines were encountered along the line of travel. The morainal material brought down by the glaciers from the remote recesses of the range and the gravels of the streams heading in the mountainous interior consist prevailingly of granitic material.

A considerable variety of rock types is found, but quartz diorites appear to predominate. A quartz diorite north of Tsadaka Creek carries the dark minerals, hornblende and biotite, and is associated with a quartz-diorite gneiss rich in hornblende. This gneiss is found also on Granite Creek and is doubtless a cataclastic phase of the massive quartz diorite. Along the middle course of Chickaloon Creek quartz-augite diorite appears, but toward the headwaters it gives place to a muscovite granite. Along the upper Talkeetna gneisses again appear, but along the lower course more quartz diorites are exposed. Along the western flank of the Talkeetna Mountains granitic rocks are exposed in great abundance almost continuously from Talkeetna River to Willow Creek and again as a narrow band 
forming the southern boundary of the crystalline mica-schist area. Near Sheep Creek some uralitic gabbro is found. In the vicinity of Kashwitna River is a light-colored quartzose type, which proves to be a quartz monzonite.

The quartz diorites on the south side of Knik Arm are probably to be correlated with those making up the main mass of the Talkeetna Mountains. Similarly a small isolated boss of epidotized quartz diorite a few miles east of the mouth of Caribou Creek appears to belong to the same general mass.

AGE.

Wherever the quartz diorites come in contact with the Susitna formation a recrystallization of the sediments has taken place and finely granular hornfels has been produced. Along the upper Chickaloon the contact of the granite with the andesitic greenstones is marked by a fine-grained marginal facies. Granite porphyries of nevadite habit, containing greenstone inclusions, appear near the contact and probably represent the chilled border of the invading granite magma.

The quartz-diorite boss east of Caribou Creek, which appears to represent a satellitic intrusion attendant on the batholith of the Talkeetna Mountains, invades the andesitic greenstones of Sheep Mountain, which have been shown by their fossils to be of lower Middle Jurassic age. Accepting the correlation of this quartz-diorite mass with those of the central portion of the province, we have strong presumptive evidence that the batholithic core of the Talkeetna Mountains is later than the Middle Jurassic. From the abundance of granitic material in the coarse conglomerates of Upper Jurassic age it is inferred that the intrusion preceded the deposition of the late Jurassic strata. The granitic complex of the Talkeetna Mountains is thus contemporaneous in a general way with that great series of batholithic intrusions of late Mesozoic age which affected the entire cordilleran region from the Straits of Magellan to the Seward Peninsula of northwestern Alaska. ${ }^{a}$

\section{UPPER JURASSIC ROCKS.}

DISTRIBUTION AND CHARACTER.

The Upper Jurassic rocks consist largely of blue shales, locally carrying fossiliferous limestone nodules. With the shales are associated various sandstones; conglomerates, and some tuffs and arkoses. Strata of this age have a wide distribution east of Chickaloon Creek, but were not observed in the Talkeetna Mountains.

${ }^{a}$ Lawson, A. C., The cordilleran Mesozoic revolution: Jour. Geol., vol. 1, 1893, p. 579.

Brooks, A. H., The geography and geology of Alaska: Prof. Paper U. S. Geol. Survey No. 45,1906 , p. 250. 
The sandstones of this series are usually ordinary yellow sandstones, which in places are conspicuous on account of the multitudes of Aucella contained in them, this fossil making up as much as one-half of the rock. In some places the sandstones have light-gray color. This is due to the fact that such beds are highly feldspathic and contain much finely comminuted black mica with an abundance locally of small bits of carbonaceous material.

On Billy Creek a number of interstratified tuff beds from 1 to 4 feet thick occur near the top of the series, a few hundred feet beneath the base of the Cretaceous. These tuffs differ greatly in appearance from the older Jurassic tuffs. They consist largely of fragments of glassy, striated feldspar, hornblende, and quartz with fine pyramidal terminations, set in an almost black matrix. Belemnites and lamellibranchs are embedded in these tuffs. Higher in the series arkoses, closely simulating granites in appearance, are interstratified with the sandstones. Coarser phases contain pieces of a fresh granitic rock-a hornblende-biotite-quartz monzonite. The arkose is composed largely of rounded and angular fragments of feldspar in a more or less advanced state of alteration. Quartz is notably absent. Deepbrown hornblende is somewhat common, and a few flakes of strongly pleochroic biotite are found. With these are associated fragments of hornblende andesite, highly altered, some of which were noted to contain large idiomorphic feldspar similar to those forming the bulk of the rock. The arkose thus appears to have been derived principally from the destruction of a volcanic land mass, but some of its material was possibly brought from a monzonite area, as indicated by the fragments of monzonite. Under the microscope the feldspars of these arkoses by their alteration contrast strongly with the clear, glassy feldspars of the somewhat older crystal tuffs already described.

A notable accumulation of conglomerate, stretching over several square miles, occurs in the headwater region of Susitna River, near the Nelchina River, where extensive glaciation has produced deep troughs that expose splendid sections of it. Perpendicular cirque walls reveal a thickness of not less than 1,100 feet. Occasional thin layers of sandstone show that the conglomerate is lying in horizontal attitude. It is almost exclusively composed of large well-rounded bowlders of augite andesite and quartz monzonite embedded in a tuffaceous matrix. In the upper horizons the bowlders of andesite preponderate. The bowlders of the conglomerate are ellipsoidal in shape, and many of them are as much as 2 feet in diameter. The conglomerate is lithified firmly enough to form large bowlders in the present stream wash.

Sheets of lava are occasionally intercalated in the conglomerate. The andesite bowlders are composed of rather fresh-looking rock, and thus differ in appearance from the older greenstone andesite. 
The augite and feldspar are comparatively unaltered, while the hyalopilitic groundmass shows a rather strong pigmentation with iron hydrate. The quartz monzonite, which carries abundant hornblende and biotite, is also of fresh, unaltered habit. It is the same type of granitic rock that is found in the arkoses on Billy Creek.

Along Nelchina River, immediately below the junction of the north and south forks, the stream bluffs reveal an interdigitation of lenses of sandstone, shale, and coarse conglomerate. The sandstones show cross-bedding and contain remains of Aucella. The conglomerates are composed of well-rounded material, bowlders a foot through being common. The prevalence of granitic rocks is noteworthy. The conglomerate masses serve to emphasize the lenticular habit of the deposit. A lens 25 feet thick and 100 feet long was found completely inclosed by sandstone. Solitary waterworn bowlders have been embedded in the center of shale lenses. These various characteristics indicate a deposit formed under near-shore conditions, probably in the vicinity of the debouchure of a swift stream. In harmony with this interpretation is that fact that the Aucella characteristic of these rocks, though a true marine species, is often found in beds interstratified with sandstones inclosing abundant carbonaceous fragments.

\section{FOSSILS AND AGE.}

The age of these strata has been determined from the following invertebrates, identified by T. W. Stanton:

Lot 6 A. K. 156. Headwaters of Nelchina River of Copper River drainage.

Cadoceras sp. Many immature speci- $\mid$ Belemnites. Fragments. mens.

The horizon is that of the Cadoceras zone, which forms the upper third of the Enochkin formation.

Lot 6 A. K. 185. Nelchina River.

Pleuromya.

Fragmentary imprint $\mid$ Belemnites.

doubtfully referred to the genus.

The horizon is probably in the upper part of the Enochkin formation.

Lot 6 A. K. 136. Billy Creek.

Aucella cf. bronni Roviller.

The same species occurs in similar rock in the Naknek formation of Kamishak Bay.

The fossils indicate faunas of both late Middle Jurassic age and Upper Jurassic age. It is interesting to note that the Upper Jurassic rocks of this region, which are faunally allied to those of the Naknek formation on the west coast of Cook Inlet, show a certain lithologic similarity in the presence of interstratified tuffs and arkose. ${ }^{a}$ Further-

a Stanton, T. W., and Martin. G. C., Mesozoic section on Cook Inlet: Bull. Geol. Soc. America, vol. 16, 1905, p. 402. 
more, an accumulation very similar to the remarkable andesitegranite conglomerate occurring on the headwaters of Susitna River is found at the base of the Naknek formation. ${ }^{a}$

\section{STRATIGRAPHIC RELATIONS.}

The late Jurassic rocks overlie the lower Middle Jurassic rocks unconformably. On Sheep Mountain, at the head of Matanuska River, sandstones and shales with a thin basal conglomerate were found resting on the eroded edges of the lower Middle Jurassic greenstones. The following measurements indicate the amount of this discordance: The strike of the greenstone tuffs is N. $12^{\circ}$ W., and the dip $50^{\circ} \mathrm{E}$.; the strike of the superjacent sandstones is N. $85^{\circ}$ W., and the $\operatorname{dip} 20^{\circ} \mathrm{N}$.

The thickness of the late Jurassic rocks (this term.embracing the late Middle Jurassic and Upper Jurassic) is not definitely known. It certainly exceeds 2,000 feet, including a known thickness of 1,100 feet of conglomerate.

Two conglomerates have been described as occurring in the late Jurassic rocks. Of these, the andesite-quartz-monzonite conglomerate overlies a portion of the late Jurassic strata, possibly of upper Middle Jurassic age, and overlaps the greenstones of lower Middle Jurassic age.

The other conglomerate occurs interstratified with shales and sandstones, carrying Aucella cf. bronni, so that it is definitely known to be of Upper Jurassic age. The granite bowlders of this conglomerate do not, however, show the striking freshness so characteristic of the granite of the other conglomerate; hence it seems to have been derived from a granitic landmass which had been exposed for a longer period to subaerial decay. For this reason the andesite-granite conglomerate is regarded as occupying a lower position in the stratigraphic column, probably near the base of the Upper Jurassic, like its analogue on the west coast of Cook Inlet.

The unconformity between the late Jurassic and the lower Middle Jurassic rocks records an important event in the dynamic history of the area. Below this break in the stratigraphic sequence the rocks are shattered and broken and in many places are rudely schistose, and the andesites have assumed a greenstone habit and in several places have been extensively pyritized and veined by quartz and calcite seams. Above the unconformity the strata lie in comparatively undisturbed attitudes, and the intercalated andesites are fairly fresh and unaltered, differing in this respect but slightly from the Tertiary volcanics of the region.

a Martin, G. C., The petroleum fields of the Pacific coast of Alaska: Bull. U. S. Geol. Surviey No. 250,1905 , p. 44. 


\section{LOWER CRETACEOUS ROCKS.}

Rocks of Lower Cretaceous age are represented mainly by a single formation-a massively bedded limestone, 300 feet thick, which overlies the Upper Jurassic strata conformably. The limestone has a limited areal distribution and is known only from the headwaters of Billy Creek and Nelchina River, where it weathers in prominent gray cliffs encircling the hilltops. (See Pl. IV, $B$, p. 42.) The limestone is white and of very finely saccharoidal texture. On fresh fracture it emits a strong fetid odor. It is readily soluble in cold hydrochloric acid, and evolves an abundance of unpleasant hydrocarbon gases. Qualitative tests show the presence of not more than a trace of magnesia. Under the microscope the detrital organic origin of this limestone is readily apparent. It is largely composed of irregular granules of dirty-looking calcite, but with these are associated numerous prismatic sections referable to organic fragments. Rhombohedral cleavage is here and there finely developed, but the characteristic calcite twinning is notably absent. Some of the carbonate is still in the aragonite form, as is indicated by negative biaxial interference figures. Accessory constituents are limpid plagioclase, quartz with hairlike rutile, hornblende, and, more rarely, augite and apatite. The incomplete conversion of the carbonate to the stable modification, and the absence of twin lamellation in the calcite indicate the essentially static conditions in which the limestone has remained since its formation.

The age determination of this Cretaceous horizon is based on the presenee of Aucella crassicollis Keyserling, obtained by Mendenhall ${ }^{a}$ from a conglomeratic sandstone at the base of the limestone. This conglomerate may indicate a time break between the Lower Cretaceous rocks and the Upper Jurassic strata in conformable sequence beneath them.

\section{TERTIARY.}

EOCENE.

DISTRIBUTION.

Strata of Kenai age were found only in the basin of the Matanuska west of Hicks Creek, underlying an area of about 380 square miles. This figure represents a minimum area, as the lower Matanuska Valley is not included in the above estimate on account of the heavy gravel sheet which effectually conceals all bed rock in that part of the region. Strata of the same age are found at Tyonek, on the west side of Cook Inlet, and at various points in Susitna Valley, but they differ considerably from those of the Matanuska region in their lith- 
ology and structure, in the absence of associated intrusives, and in the character of the interstratified coal seams. Rocks of Kenai age are widely distributed throughout Alaska, but usually in areas of restricted extent.

\section{CHARACTER.}

The Kenai of the Matanuska basin comprises a series of sandstones, shales, arkoses, numerous coal seams, and a large volume of conglomerate. The rocks are well indurated, and, as first noted by Mendenhall, resemble the Paleozoic coal measures of the Appalachian region. The sandstones are gray, hard, and tough, and are characterized by the presence of silvery shreds of white mica. At some localities, as in the leaf-bearing strata in the Kings Creek coal measures, the sandstones contain shale fragments. The shales show no unusual features; they are dark-bluish, fissile, and interstratified with the sandstones in very regular beds. The arkoses were noted only on the ridge north of Tsadaka Creek, abutting against the quartz-diorite mass. They are composed of feldspar, quartz, and chlorite, and locally contain granite pebbles. Certain strata are fine examples of regenerated granites.

Conglomerate is found at Castle Mountain, between Kings and Chickaloon creeks, and at Conglomerate Mountain, between Tsadaka and Eska creeks. (See Pl. III, A, p. 16.) At both places the deposit is at least 1,000 feet thick. Thin sandstone beds, not exceeding a few feet in thickness, are intercalated with the conglomerate and pinch out along the dip. The pebbles of the conglomerate are well worn and possess a well-defined shingling. Their diameter averages 4 inches and ranges up to 8 inches. Greenstone porphyries form the principal material of the conglomerate, with some quartz porphyry and very rarely some granite and vein quartz. The matrix of the pebbles is a grit.

Mendenhall ${ }^{a}$ describes the conglomerate of Castle Mountain as follows:

This bed is probably not less than 1,000 feet thick, 600 feet of it having been measured, and the estimated height of the cliff above me at the time of the measurement being 300 to 400 feet. The heavy conglomerate plates, which together make up the mountain, are separated by thin sandy shale sheets, which constitute but an insignificant quantity of the mass. The pebbles of the conglomerate contain a great variety of rocks, among them many igneous types. They are rounded and vary in size up to a foot in diameter. Overlying the Castle Mountain bed is a body of soft shales with a cap of red sandstone.

Heavy beds of conglomerate dipping to the north can be seen on the east side of Chickaloon Creek. They are part of a great series of

a Mendenhall, W. C., A reconnaissance from Resurrection Bay to the Tanana River, Alaska, in 1898 : Twentieth Ann. Rept. U. S. Geol. Survey, 1898-99, pt. 7, p. 308. 
sandstones, shales, and conglomerates, probably not less than 3,000 feet thick, which are overlain by basaltic porphyries at an elevation of about 4,700 feet. Canyons cut through this series of rocks have nearly vertical walls and give to the mountains a massive castellated form. (See Pl. III, $C$, p. 16.)

The coal of the Kenai of the Matanuska basin is bituminous except where modified by igneous rocks. The seams vary in thickness up to a maximum of 17 feet.

FOSSILS AND AGE.

The age of these beds has been determined from their fossil plants. These have been submitted to F. H. Knowlton, who reports as follows:

This material, consisting of six small lots, is in the main very poorly preserved and insufficient in quantity to make the report of fullest value. The various localities and the forms detected at each are as follows:

Tradalca Creek, 25 feet above 11-foot coal seam. Age, Kenai.

Sequoia langsdorfii (Brgt.) Heer.

Ficus? grönlandica? Heer.
Magnolia inglefeldi Heer.

Fragments of other dicotyledons.

Kings Creek coal. Age, apparently Kenai.

Ficus? grönlandica Heer.

Populus arctica? Heer.
Rhamnus eridani Heer.

Viburnum sp., cf. V. nordenskiöldi Heer.

Arkose Ridge, north of Tsadaka Creek. Age, apparently Kenai.

Taxodium distichum miocenum Heer. Ficus? grönlandica? Heer.

Taxodium tinajorum Heer.

Populus sp.?

Paliurus colombi Heer.

Fruits, cf. Leguminosites sp.

Chickaloon coal strata, Watson's camp. The age indicated is Kenai.

Sequoia langsdorfii (Brgt.) Heer.

In addition to this form Martin collected:

Taxodium distichum miocenum (Brgt.)

Heer.

Salix varians Heer.
Populus arctica Heer. Corylus macquarii (Forbes) Heer. Juglans nigella Heer.

In addition to the plant remains, shells have been found by Martin in the thin ironstone (No. 17) in the section on page 12 of his report. ${ }^{a}$ Stanton says:

This lot (No. 3316) consists entirely of fresh-water gasteropods, of which all but one specimen belong to a single species of Viviparus of a type that occurs in both the upper Cretaceous and the Tertiary. The other specimen is a more slender form, too imperfect for generic determination. These fossils are apparently an undescribed species-at least they are new to Alaska-and they do not fix the horizon more closely than is above indicated. 
The evidence from the flora of these beds shows, therefore, that they belong to the Kenai, which is regarded as of upper Eocene age. The evidence from the fossil gasteropods is valuable in confirming the fresh-water origin of this thick series of strata and, in a general way, their late Cretaceous or Tertiary age.

STRATIGRAPHY.

The thickness of the Kenai in this field is not definitely known, but is over 3,000 feet, of which 1,000 feet, near the top of the series, consists of the conglomerate.

The stratigraphic relations of these Tertiary strata to the older rocks are complex. North of Tsadaka Creek, where arkoses come in contact with granitic rocks, simple erosional unconformity is suggested. West of the Little Susitna there is evidence that the position of the sandstone beds against the crystalline rocks is due to faulting. At one locality the beds overlie at a considerable angle crystalline mica shists, while a mile or two farther west a granite similar in type to the central granite mass has taken the place of the sandstone beds against the schists, and the sandstones lie farther south, against the granite. (See Pl. II, pocket.) Along the south flank of Anthracite Ridge the Kenai has been faulted against Jurassic beds.

The Kenai beds have been folded and faulted since they were laid down. The folding is at some places of a sharp, asymmetric character. On account of the presence of coal beds in the Kenai, it is thought best to present the main discussion of its structure in the description of the coal fields.

\section{IGNEOUS PHENOMENA.}

Dikes and sills of diabase are numerous in the Kenai rocks of the Matanuska region, especially in the region east of Chickaloon Creek, where they form prominent "trap ridges." The thickness of the intrusives ranges from several feet up to several hundred. Equally noticeable variations in grain, ranging from extremely fine-grained to coarse ophitic textures, are easily recognized by even the naked eye. At Anthracite Ridge one of these dikes, 75 feet thick, composed of augite and labradorite, has exerted strong contact metamorphism on the adjoining shales, baking them into a porcelanite zone 8 inches thick.

The igneous sheet overlying the shales on Kings Creek at the coal prospects differs petrographically from the prevailing diabase intrusives of the region. It carries porphyritic feldspars in a lightcolored granular groundmass and has been determined microscopically to be a monzonite porphyry.

The effect of these dikes and sills on the coal is of particular interest. Wherever they cut the coal or come close to it they have converted it 
to a hard, dense colke. Besides this local effect the presence of thick sills in the coal-bearing rocks appears to have raised the grade or fuel value of the coal. As will be shown under the discussion of the mineral resources, the Matanuska coal field can be divided into two districts, of which one, the western, contains low-grade bituminous coal, approaching lignites in composition, while the other, the eastern, contains high-grade bituminous coal. The difference in character of the coals can not be explained as due to difference in intensity of folding in the two districts. Igneous intrusives are absent from the western district, but are prevalent in the eastern. This association of high-grade coal with abundant intrusives is at least suggestive. Furthermore, it is probable that the anthracitic character of the coal of Anthracite Ridge is due to the presence of unusually thick and abundant dikes in rocks of Kenai age.

COMPARISON WITH ADJOINING REGIONS.

The Kenai rocks of Matanuska Valley differ markedly from those of the type section of the Kenai as exposed on Kachemak Bay, on Cook Inlet, ${ }^{a}$ where the sandstones are soft and incoherent, the shales are plastic when wet, and the lignite seams form the resistant members. The beds on Kachemak Bay lie at low angles in undisturbed attitudes. The lignite is in general hard and glossy, but in the higher seams becomes dull and shows a more woody fiber. The lower seams have been buried under a depth of nearly 10,000 feet of strata.

If the Kenai of Matanuska Valley be compared with the Kenai exposed at Tyonek, the contrast is even greater, though Tyonek is nearer than Kachemak Bay. The Kenai at Tyonek consists " of alternating beds of. clay, sand which has hardened to sandstone in huge nodules, and lignite." ${ }^{b}$ According to Eldridge, the lignite in places hardly appears to be more than a compressed mass of carbonized wood. The strata are tilted at angles ranging from $35^{\circ}$ to $60^{\circ}$. Though more sharply deformed, the coal is of lower grade than that of Kachemak Bay.

From the foregoing comparisons it appears that the Kenai of Matanuska Valley differs considerably from that of the adjacent regions in its higher degree of induration and in the superior quality of its coal seams. The conclusion can be drawn that the higher character of the Matanuska coal is due not to conditions of deeper burial or sharper folding, but to the prevalence of intrusives in the coal-bearing strata.

${ }^{a}$ Stone, R. W., Coal fields of the Kachemak Bay region: Bull. U. S. Geol. Survey No. 277,1906 , p. 58.

'Spurr, J. E., Reconnaissance in southwestern Alaska in 1898: Twentieth Ann. Rept. U. S. Geol. Survey, pt. 7, 1898-99, p. 102. 


\section{POST-EOCENE.}

Overlying the older rocks unconformably is a series of nearly horizontal basalt flows, which, with their intercalated pyroclastics, attain a thickness of 1,000 feet. They have an extensive distribution throughout the Talkeetna Mountains and compose many of the peaks and summits of the region. They weather in tints of red and break down in characteristic erosional forms which lend a picturesque castellated appearance to the mountain crest lines.

The basalt flows with their interbedded tuffs and breccias present a stratified appearance. The surface upon which these volcanics were accumulated appears to have been one of gentle relief, cut across the upturned edges of the older rocks. The discordance with which the nearly horizontal basalts rest upon the underlying strata varies from $10^{\circ}$ to $90^{\circ}$. About the headwaters of Chickaloon Creek this surface slopes gently northward. East of Chickaloon Creek its altitude is about 5,000 feet. It is somewhat broken by small faults, the maximum displacement noted being 50 feet. At many places the basalts rest upon a conglomerate occupying broad channels in the Lower Cretaceous limestone. The basal portion of the volcanic series here consists of 100 feet of tuffs and amygdaloid breccias, which interleave with the sandstone beds in the upper portion of the conglomerate. The conglomerate consists of rather coarse wash embedded in a gravelly matrix. The pebbles are well rounded, though poorly sorted and shingled, and cobbles up to a foot or more in diameter are common. The material is largely of volcanic origin, consisting principally of greenstone amygdaloids and eutaxitic rhyolites-extrusives of Jurassic age. Some irregular lenticular beds of sandstone are included in the conglomerate. It is 200 feet thick, and in the vicinity of Billy Creek fills a channel 1,000 feet wide, cut in the Cretaceous limestone and partly in the underlying sandstones. The arclike line of contact is finely exposed in the deep canyons tributary to Billy Creek. This conglomerate, whose fluviatile origin is thus apparent, has a very limited distribution and has been preserved only where buried under the covering of basaltic lavas. This conglomerate is later than Lower Cretaceous, but further than that its age is not known. Lithologic similarity suggests its correlation with the great mass of conglomerate occurring in the upper horizons of the Kenai in Matanuska Valley.

Locally the conglomerate is capped by an angular wash consisting of fragments of sandstone and cellular lavas, upon which rests the stratiform series of basalts and pyroclastics. At one point a breccia of unusual constitution was found near the base of the volcanic series. This breccia consists of large angular blocks of highly amygdaloidal 
lava, blocks of sandstone containing Aucella, and a few blocks of the Cretaceous limestone characteristic of the region. A basalt block 8 by 10 feet was the largest noted. The matrix in which this angular material is embedded is composed of small, well-rounded gravel. These features are interpreted as indicating a volcanic mud flow occupying an ancient stream course.

The overlying basalts display a wide variation in habit and texture. Highly glassy types, amygdaloids, porphyries, and dolerites are variously represented. They belong to the acidic end of the basalt family and are in general non-olivinitic. The coarse-grained basalts consist of doleritic aggregates of labradorite $\left(\mathrm{Ab}_{2} \mathrm{An}_{3}\right)$ and augite. Plagioclase is the dominant constituent, and is. in only a few specimens poikilitically inclosed in the augite. The basalt glass from the head of Chickaloon Creek, in spite of its holohyaline aspect, is found to contain sporadic phenocrysts of plagioclase $\left(\mathrm{Ab}_{2} \mathbf{A n}_{3}\right)$ and augite, and some small, irregularly shaped doleritic aggregates of labradorite and augite. The glassy base is of a deep, clear, brown color, and contains numerous augite and very minute feldspar microlites, the latter usually having forked terminations.

The basalts overlie a conglomerate of post-Lower Cretaceous origin and of probably late Kenai age. Their petrography suggests that they are the effusive equivalents of the diabase dikes and sills that are so common in the Kenai of the Matanuska basin. These volcanics of the Talkeetna Mountains can be correlated with the great series of Tertiary volcanics of the upper Nizina basin, described by Schrader and Spencer, and with an important volcanic series on Nabesna River, described by Brooks. Both these series are described as comprising andesites, rhyolites, and pyroclastics, and were deposited unconformably upon a general uniform surface. The volcanics of the Talkeetna region, however, show a greater petrographic uniformity and consist exclusively of basalts and their fragmental accumulations. In this respect they show a closer resemblance to the late Tertiary lavas of the Alaska Peninsula and the Aleutian Islands, which have been described by Spurr ${ }^{a}$ as andesitic basalts.

\section{QUATERNARY DEPOSITS.}

Extensive deposits of glacial and fluvioglacial gravels are prevalent. They extend entirely around the head of Cook Inlet, forming bluffs 50 to 100 feet high. Below Knik the gravel consists largely of subangular to rounded pebbles of hornblende-biotite granite and graywacke, with occasional muscovite-biotite granite, pyroxenite, and andesitic porphyries. Enormous angular blocks are frequently in-

a Spurr, J. E., A reconnaissance in southwestern Alaska in 1898: Twentleth Ann. Rept. U. S. Geol. Survey, pt. 7, 1900, p. 234. 
cluded in this stream-worn material. Many of these have smooth, polished surfaces several feet square, much scratched and grooved. The gravel sheet at Tyonek, on the west side of Cook Inlet, with its extension up Susitna Valley as far as Chulitna River, has been recognized as divisible into an older and a younger formation. The older apparently consists of the ground moraine of an advancing ice - stream, ${ }^{a}$ and the younger includes fluvioglacial gravels deposited upon the earlier sheet during the recession of the ice. These distinctions can not be drawn in the Matanuska region. The gravel sheet in Matanuska Valley is of considerable areal extent and mantles the old valley floor, especially in the region west of Chickaloon Creek. The gravels near the mouth of Kings Creek have a maximum thickness of about 300 feet. They are greatly waterworn, and the icerafted bowlders so conspicuous in the vicinity of Knik Arm were not observed. However, the fact that the bluff near this exposure in Matanuska Valley is composed of shales shows that gravels were deposited on a surface of irregular relief, or possibly in channels. This is also shown by the fact that the walls of the Matanuska gorge are in places composed of bed rock, and in other places of gravel.

In its upper course Matanuska River has cut a V-shaped gorge in the deposits underlying the southwest corner of the Copper River Plateau. The gravels here consist of angular blocks, scratched and striated, inclosed in a blue, clayey-sandy matrix. The river has cut down 300 to 400 feet in this glacial till, but does not yet reveal bed rock. Farther north, in the Copper River Plateau, stream bluffs on a tributary of the Nelchina show coarse gravels of subangular to well-rounded character. With this stream-worn material are associated numerous glacially scored bowlders and occasional angular blocks up to 10 feet in size. The gravel shows considerable variety in its petrographic charcter, including numerous fragments of granite, gabbro, gneiss, schist, slate, graywacke, and vein quartz. None of these rocks are found in the drainage area of this stream, so that the fragments appear to have come from the Alaska Range.

\section{GEÖLOGIC HISTORY.}

PRE-QUATERNARY.

The oldest records of the geologic history of the region are preserved by the albite and garnetiferous mica schists. They appear to represent a series of calcareous argillites and plagioclase arkoses, recrystallized under conditions of deep burial. Subsequent to their metamorphism they have been uplifted, intruded by pyroxenite dikes, and subjected to a second period of dynamic activity. The dikes

${ }^{a}$ Spurr, J. E., op. cit., p. 102. 
were thus sheared and the component minerals of the schists were crushed. The highly crystalline character of the schists and their isolated occurrence as a single narrow belt indicate the completeness of the geologic revolution which the region has undergone since their formation. On the basis of petrographic similarity these schists are correlated with those of the Yukon-Tanana region and assigned to a pre-Silurian age.

The time interval between the deposition of these oldest rocks and that of the Susitna slate is not known, but appears to have been of considerable duration, as is indicated by the far less advanced metamorphism of the latter. The Susitna comprises fissile slates, foliated graywackes, and microcrystalline hornblende and biotite schists. The possibility, however, that they may be contemporaneous in origin with the rocks of the Sunrise "series" is not excluded.

In late Paleozoic or early Mesozoic time sedimentary conditions prevailed over the region now occupied by the Chugach Mountains, and an extensive series of shales, arkose, and ferromagnesian sandstones derived from the destruction of a quartz-diorite land mass were laid down. Volcanic activity interrupted the normal sedimentary sequence and caused the accumulation of greenstone tuffs, associated with some massive basaltic greenstones. Rhyolitic lavas were also poured out, and the accompanying fragmental material was mingled with the sediments derived from the erosion of the granitic land area. Subsequently these deposits were closely folded and metamorphosed to graywackes, slates, and, locally, to phyllitic schists.

At the beginning of Middle Jurassic time marine conditions were inaugurated. Eruptive activity was then widespread throughout the region of the Talkeetna Mountains, and andesitic greenstone breccias with intercalated amygdaloids were accumulated to a thickness of 1,000 feet. The relations of land and sea appear to have been unstable during this period, and a portion of the volcanics were doubtless extruded upon uplifted land areas. The exceedingly coarse volcanic conglomerates show the effectiveness of erosional agents, and the composition of the succeeding sandstones indicates their derivation from an andesitic land area.

Toward the close of the Middle Jurassic, quartz diorites forming the core of the Talkeetna Mountains were intruded and the Talkneeta area was uplifted. A vigorous denudation ensued, the sedimentary roof arching over the plutonic rocks was stripped off, and the granolites were uncovered.

By the beginning of the Upper Jurassic the granitic land mass thus laid bare furnished large amounts of material to the conglomerates then accumulating. Some andesitic eruptions occurred at this time. The relief of the land mass was soon subdued, and the succeeding sediments became normal sandstones and shales, interstratified with 
occasional arkoses and crystal tuffs. Marine conditions persisted uninterruptedly until the close of Lower Cretaceous time. The final stages were marked by the deposition of a heavy limestone, now largely removed by erosion.

The revolution at the close of the Lower Cretaceous, as in adjacent regions, was of a gentle character. The strata involved were uplifted with but slight deformation and without folding. After this upheaval there came a long period of erosion and planation. In the Matanuska region, however, diastrophic movements produced a trough of fresh-water sedimentation in late Eocene time, and a thick series of arkoses, shales, and sandstones, with numerous coal beds were laid down. The arkoses, occurring probably at the base of the formation, indicate strong relief in the adjacent land mass at the beginning of Kenai time. During the progress of sedimentation erosion of the Talkeetna area continued and furnished the material for the Kenai deposits. At the close of the Eocene the strata were uplifted and sharply folded. Peneplanation, however, was far advanced in the Talkeetna area, especially on the flanks of the region. Broad rivers, whose beds were filled with well-rounded gravels, flowed over its surface.

This period of quiescence was finally closed, shortly after the folding of the Kenai, by a great outburst of volcanic activity. Drainage conditions were destroyed, lavas flooded the stream channels, and the fluviatile accumulations were buried to a depth of 1,000 feet under a succession of basalt flows and tuffs. While this extravasation of volcanic material occurred throughout the Talkeetna area an extensive series of diabase dikes and sills were injected into the Kenai strata of the Matanuska basin.

With the cessation of volcanic activity a new cycle of erosion was begun, initiating the modern history of the region.

\section{GLACIATION.}

\section{PRESENT GLACIATION.}

A considerable number of glaciers still remain in the higher portions of the Talkeetna Mountains (see Pl. I, pocket), but all appear to be rapidly receding. Chickaloon Creek and many of its tributaries are fed by glaciers at their sources. Of these Chickaloon Glacier, at the head of the stream of that name, is the largest, having a length of 9 miles and a width of 2,000 feet at its terminal end. In general, however, the ice streams do not descend far from the irregular névé fields occupying the higher recesses of the range. Several such masses lie on the Talkeetna side of the Chickaloon-Talkeetna divide and discharge their waters into that stream. 
Evidence is plentiful that the glaciers are rapidly retreating. Lateral morainic material perched 150 feet above the sides of Chickaloon Glacier indicates a recent dwindling in the size of that glacier. Some of the small glaciers no longer join the trunk ice stream, but have become independent glaciers, whose troughs are elevated above the surface of the main glacier. (See Pl. IV, D, p. 42.). After the recession of the ice a growth of moss encroaches on the canyon walls which confine the glaciers. Where recent retreat has taken place a considerable interval of bare wall intervenes between the present position of the glacier and its former position, as indicated by the mossgrown profiles on the rock walls.

In addition to the glaciers at the head of Chickaloon Creek, a small glacier occurs at the head of Kings Creek and another at the head of Little Susitna River. Of the glaciers on the south side of Matanuska Valley, Mendenhall says: ${ }^{a}$

Along the middle course of the river several small ice streams are to be seen at the heads of the canyons which furrow the southern valley wall, but the largest glacier of the valley is the Matanuska Glacier with a frontage of 3 miles along the river. The course of this stream can be traced from the top of Glacier Point for 25 or 30 miles to the southeast. Its source here is probably in the néve which follows the crest of the Chugach Range to the east, and gives rise to the various glaciers which flow down to Prince William Sound on the the south and to the Tazlina and Klutina rivers on the north. While its east front is buried under moraine which supports a considerable spruce forest, the west front is clear of debris to the edge. A well-marked medial moraine divides the main stream into two parts, representing branches which unite near the source. Local conditions of precipitation controlling the rate of flow of these tributaries seem to be slightly different, so that the western branch is somewhat more active than the eastern one.

Within 10 miles of its source the Matanuska River receives the. waters from another glacier, smaller than that just described and more actively retreating. Its front has now receded several miles from the river and the draining strean flows through a gravel-filled valley with a very high gradient.

At the head of Knik River lies the Knik Glacier, whose width is $2 \frac{3}{4}$ miles. It is not much smaller than the Matanuska Glacier. Knik Glacier forks a few miles back from its terminal end, one fork extending eastward about 20 or 25 miles, probably to the same ice field that is drained by the Matanuska Glacier, the other fork extending southwestward. The latter fork again divides. In its western prong is a large lake 5 miles long and $1 \frac{1}{2}$ miles wide, whose waters are apparently impounded by the extension of the lateral moraine of the eastern prong across the mouth of the trough of the western prong. Bergs were seen floating in the lake. According to local report the breaking of this morainal dam was the cause of the disastrous flood which swept down Knik River some years ago.

a Mendenhall, W. C., A reconnaissance from Resurrection Bay to Tanana River, Alaska, in 1898 : Twentieth Ann. Rept. U. S. Geol. Survey, 1898-99, pt. 7, p. 327. 
The front of Knik Glacier rests upon a gravel p'ain covered with well-rounded stream wash. Irregular heaps and ridges of this gravel 12 feet high lie in front of the glacier for 400 feet. Pits and kettle holes 6 to 8 feet deep are common. On the western side of the glacier an accumulation of large angular blocks of graywacke and slate, constituting the dump of the superglacial material, forms a narrow peripheral moraine nearly a mile long. In profile as exposed on its extreme western edge the glacier can be seen resting upon bed rock; which here begins to rise rather steeply from under the gravel covering of Knik Valley. The recent history of the Knik Glacier, as interpreted from the above features, shows a recession from a temporary advance over the gravel deposit of the valley.

PAST GLACIATION.

The existing glaciers are the shrunken remnants of a system of ice streams which had a vastly greater extent in the recent past. At the time of its maximum expansion this mighty system included the enormous piedmont glacier ${ }^{a}$ of the Copper River basin, and the trunk glaciers occupying Matanuska, Knik, and Susitna valleys, which were probably confluent at the head of Cook Inlet.

During the occupancy of the lowlands by these great ice streams, the Talkeetna Mountains were subjected to severe alpine glaciation, to which the ruggedness of the present topography is largely due. (See Pl. IV , $C$, p. 42.) In higher portions of the range the glacial erosion has often proceeded to its most destructive lengths. Knifeedged divides are numerous throughout the region, and instances of the obliteration of divides and the coalescence of opposing cirques are frequent. All the existing glaciers occupy the heads of $U$-shaped troughs. The finest example of such troughs is that along the upper course of Talkeetna River, which is perfectly straight for 18 miles.

The former presence of a great glacier once filling Matanuska Valley is indicated by abundant evidence. At the head of the valley the morainal ridges of the Copper River basin curve round into Matanuska Valley. An isolated hill about 500 feet high, projecting above the lake-covered flat at the head of the valley, shows an abrupt stoss side toward the Copper River basin, and a long, smooth lee slope toward Matanuska Valley. Along the upper course of the valley on the flank of Sheep Mountain glacial gravels of various exotic types are found at an elevation 1,500 feet above the valley floor. These facts indicate that the ice of the southwestern portion of the Copper River basin drained into Matanuska Valley in a stream not less than 1,500 feet thick. Passing farther westward we find that

\footnotetext{
${ }^{a}$ Mendenhall, W. C., Geology of the central Copper River region, Alaska; Prof. Paper U. S. Geol. Survey No. 41,1905 , p. 72 .
} 
the summit of the irruptive boss on the west side of Kings Creek is smoothed and glacially scored; and that betwen Eska and Granite creeks on the flanks of the valley a heavy lateral moraine, consisting of large angular bowlders of various granitic rocks, rests 2,400 feet above the river. Near tide water the buttes in the middle of the gravel plain of Matanuska Valley are striated and strongly fluted on their summit, 700 feet high.

This evidence is supplemented by that furnished by the physiography. A marked feature of Matanuska Valley, as seen from Knik Arm, is the appearance of triangular faceting cut on the left wall of the valley. This feature is due to the truncation of the projecting ridges between the streams tributary to the main valley, whereby the spurs have been replaced by steeply sloping planes with triangular outlines. This feature, it may be mentioned, has been developed in almost geometric perfection in the region of Turnagain Arm on Kenai Peninsula, but nowhere on the same large scale as in lower Matanuska Valley.

The evidence is equally strong that Knik Valley was formerly occupied by a large ice stream. Along its middle course glaciated surfaces are found 1,500 feet above the gravel floor of the valley. A minimum estimate is thus fixed for the thickness of the glacier.

On the Susitna side of the Talkeetna Mountains evidence of glacial action even more pronounced than that on the eastern side is visible on every hand. The mountains are bordered by a more or less irregular bench several miles wide, approximating 2,500 feet in elevation. Its surface is noticeably glaciated, rounded hillocks, smoothed outcrops, glacial débris, and numerous undrained lakes characterize its topography. Streams entering the Susitna pass at the mountain borders through beautiful glacial U-shaped valleys, their smaller tributaries entering these valleys through sharply incised, vertical-walled canyons, an evidence of recent cutting. The rise from this broad bench to the mountains eastward, when compared with the gentle slope of the bench to the Susitna, is steep.

It is probable that an ice sheet that occupied the entire Susitna Valley and was fed from the surrounding mountains once moved southward to Cook Inlet. The tributaries from the Talkeetna Mountains to Susitna River all present clear evidence of having been occupied by ice streams. Glacial U-shaped valleys and erratics occupying positions no longer within the reach of ice movements are traces of the mantle that covered much at least of the present drainage system.

It is probable that after the recession of the huge ice mass occupying Susitna Valley glacial action continued in the smaller streams for a considerable period. This is indicated by the fact that the gla- 
cial U-shapes on the western slope of the Talkeetna Mountains are considerably lower than the broad ice-sculptured bench 2,500 feet high.

\section{PHYSIOGRAPHIC DEVELOPMENT.}

The region under discussion falls naturally into three physiographic provinces: Matanuska Valley, Talkeetna Mountains, and Copper River basin.

\section{MATANUSKA VALLEY.}

According to Mendenhall, Matanuska Valley is probably due to simple erosion somewhat modified by ice action. ${ }^{a}$ In a subsequent report he has suggested that the southern edge of the Copper River basin is probably a fault or a sharp flexure. ${ }^{b}$ The westward prolongation of this fault would coincide with the southern wall of Matanuska Valley. Martin ${ }^{c}$ remarks that the Matanuska Valley suggests a "graben" or sunken area within parallel faults, but notes that this appearance may be due to the more resistant character of the rocks bounding the valley. The exact mode of origin of Matanuska Valley can not yet be regarded as established. It is beyond question true, however, that if of tectonic origin the valley has subsequently been largely modified by stream erosion. In proof of this is the fact that it possesses the form of a normal stream-wrought valley, narrow in its upper course and broad in its lower. From a width of 1 mile at the Copper River basin Matanuska Valley widens to 20 miles near Cook Inlet. Knik Arm appears to represent a slight drowning of lower Matanuska Valley, from which the region is at present recovering.

There is some evidence available that recent movement has taken place along the northern side of the valley. Along its upper course Sheep Mountain presents a steep, rugged front facing the river. At the base of the ridge the strata are shattered and an extensive disruption of the injected dikes has taken place. Extensive alluvial breccia cones spread out into the valley for a mile or more from the mouths of the ravines. The steep slope of these cones $\left(6^{\circ}\right.$ to $\left.10^{\circ}\right)$ and their symmetrical development make them noteworthy features of the topography. The formation of such detrital cones is held by workers in the Western States to be due to a sudden break in the stream profile at the point of deposition, usually by recent faulting, rather than to arid conditions, which was first invoked in their explanation.

The present Matanuska River occupies a wide trench sunk into an older, broader valley averaging 5 miles or more in width. The

a Op. cit., p. 239.

${ }^{\circ}$ Mendenhall, W. C., Geology of the central Copper River region, Alaska: Prof. Paper U. S. Geol. Survey No. 41,1905 , p. 87.

Op. cit., p. 17. 
trenching of the old valley appears to have begun in preglacial time, but was interrupted by the glacial advance. The ice occupancy effected some erosion, notably on the south side of Knik Arm, but left pronounced irregularities of relief in the floor of the valley, such as Glacier Point and the bed-rock bosses at the mouth of the Matanuska. On the recession of the ice a heavy mantle of gravel was laid down. A succession of slight uplifts followed, as expressed in the finely terraced character of the affluents of the Matanuska, and the streams began to remove the gravels from their channels and to deepen their trenches. The excavation of the gravels has been incomplete along the Matanuska, where long stretches of stream bluffs consist of gravel banks. These features suggest that either the preglacial drainage had begun to swing in its course or that glacial erosion has modified the valley floor, and that the irregular bed-rock relief thus produced has been obliterated by the gravel deposits subsequently laid down. The former supposition is regarded as the more probable, and the great bend of the Matanuska appears to be an incised meander inherited from the preglacial drainage. The present - overloaded condition of the Matanuska is due to the vigorous trenching of the deep glacial gravels at its headwaters.

\section{TALKEETNA MOUNTAINS.}

The internal structure of the Talkeetna Mountains suggests that they belong to a province geologically distinct from that of the Chugach Mountains. The latter, as shown by Schrader, Spencer, and others, represent a belt of intense crustal shortening. In the Talkeetna Mountains, however, the strata are comparatively undisturbed. The younger rocks especially have been but gently affected by orogenic movements. The faulting is normal, implying a stretching of the earth's crust.

The early Tertiary history of the Talkeetna area has already been sketched. It was shown that, coeval with the deposition of the Kenai, a peneplain of considerable perfection was developed over the region of the Talkeetna Mountains. The older age limit of this planation is fixed by the fact that the surface is in part cut across a Lower Cretaceous limestone. The later limit is determined by the fact that the fluviatile conglomerates, resting upon the peneplain, appear to represent the similar conglomerates oceurring at the top of Kenai or in the Matanuska basin. According to this view the conglomerates at the top of the Kenai represent the period at the close of lacustrine conditions, and the conglomerates in the Talkeetna area are the fluviatile accumulations of the rivers which transported the materials of the Kenai sediments. During the later stages of peneplanation and the formation of the fluviatile conglomerates, the land 
mass doubtless stood at a lower level relative to the sea. Some time after the flooding of the region with basaltic lavas, a domal uplift of the area was inaugurated, probably accompanied by faulting along the north side of Matanuska Valley. North of Talkeetna River the old surface, buried beneath the basalts, can be seen dipping gently northward. Eastward, from an altitude of about 5,200 feet, it appears to merge gradually into the flats of the Copper River basin at 3,000 feet. This arching demanded a stretching of the earth's crust, and as a result the numerous small dislocations of the basement upon which the volcanics rest were produced. The domal character of the uplift is expressed in the general radial drainage, the main streams flowing from the center of the region. The shortness of the streams tributary to the Matanuska, in comparison with those flowing to the Susitna, appears to indicate an obsequent origin for this portion of the drainage.

Along the western flank of the Talkeetna Mountains a broad bench several miles wide parallels Susitna River at an altitude of about 2,500 feet. The surface of this bench has been considerably modified by glacial erosion, and a mammillated topography has been impressed upon it but does not obscure its terrace character. Tributaries of the Susitna have cut normal stream valleys across it, many displaying marked evidence of a position at base-level in their recent history by the intricate and beautiful systems of oxbows developed at an elevation of about. 500 feet. Below these stretches of oxbows the streams enter sharply incised canyons, whose small amount of recession indicates the comparative recency of the latest uplift of the region. It appears probable that the stage of the oxbows represents a halt in the greater uplift which has given the broad bench its present elevated position.

\section{COPPER RIVER BASIN.}

The Copper River basin has been discussed in some detail by Mendenhall, who advanced the hypothesis, as one most consistent with the facts, that it is of tectonic origin, representing a depressed area between the Alaska Range on the north and the Chugach Range on the south. ${ }^{a}$ The relation of the Talkeetna Mountains to the basin was not discussed. Certain facts in the region under consideration appear to favor Mendenhall's hypothesis.

On the western edge of the basin, near the head of Matanuska River, the hills rise abruptly from the plateau. Their summits form a gently rolling surface at an average altitude of 5,000 feet and evidently constitute a remnant of the ancient peneplain upon which,

a Prof. Paper U. S. Geol. Survey No. 41, 1905, p. 88. 
farther west, at an altitude of 5,200 feet, were found the river channels buried beneath lava. These features strongly suggest faulting along the base of the hills, the old plain being broken off along this line and its eastward extension buried beneath the glacial débris of the Copper River basin. Farther northwest, however, the Talkeetna Mountains gradually merge into the lowlands of the Copper River basin-a fact indicating, perhaps, that faulting gives way in this direction to warping of the crust.

\section{MINERAL RESOURCES.}

COAL.

\section{AREAL DISTRIBUTION.}

Coal outcrops have been examined on Tsadaka, Eska, Kings and its tributaries, Chickaloon, Coal, Hicks, and Billy creeks, and the north fork of Nelchina River; along the southern flank of Anthracite Ridge; and in the banks of Matanuska River, about 3 miles above the mouth of Chickaloon Creek. In addition, coal float has been found close to its source on Glacier Creek, and as far north as the south fork of the Tyonek. Coal has also been reported from Little Susitna River, Willow Creek, the Kashwitna, and the Chunilna, and from a creek on the south side of the Matanuska, 9 miles above Coal Creek.

The field work of 1906 extended the known area of Tertiary coalbearing rocks approximately 18 miles up Chickaloon Creek, though no outcrops of coal were observed. The discovery of an area of Mesozoic rocks in Matanuska Valley extends the field also in that direction, as is indicated on the map, though all the coal that outcrops north of Anthracite Ridge between Hicks and Boulder creeks is lignitic.

So far as known the Tertiary coal-bearing rocks in the Matanuska cover an area of about 380 square miles. The known coalbearing rocks of Mesozoic age in the upper Matanuska basin cover approximately 500 square miles. The areal extent of the divisions is shown on the map (Pl. II, pocket), and the character of the beds has been described on page 25 . The mapping of the coal-bearing rocks must in no sense be taken to mean that areas so mapped are underlain by workable coal. So far as known the actual area underlain by coal from Moose Creek to Hicks Creek, inclusive, approximates 70 square miles. Localities where coal of commercial importance has been observed will be described.

The area of coal-bearing rocks can be subdivided from an economic standpoint into three fields:

(1) The Matanuska field, comprising the valley floor of Matanuska River west of the mouth of Hicks Creek. This field is underlain by a 
series of Tertiary strata containing bituminous coals of various grades.

(2) The Anthracite Ridge field, forming a limited area along the southern flank of the Talkeetna Mountains between Boulder and Hicks creeks. The coal here is an anthracite, the age of which has not yet been determined with certainty.

(3) The northeastern field, comprising the area drained by the headwaters of Matanuska River and the adjacent areas in the Copper and Susitna drainages. The coal, which is of Jurassic age, is generally lignitic, but locally is semianthracitic.

MATANUSKA FIELD.

EXTENT.

The area of Tertiary coal-bearing rocks found in the Matanuska basin is approximately 380 square miles, of which 70 square miles are actually underlain by coal, according to a most conservative estimate.

\section{STRUCTURE.}

The coal-bearing rocks have a strike in general parallel to the easterly trend of Matanuska Valley. The dips are variable, with a tendency toward steep angles. East of Tsadaka Creek, where the gorge of Matanuska River exposes a voluminous succession of sandstones and shales, the strata stand on edge. The folding is open, although locally, as in the anticline on Chickaloon Creek, the deformation may be quite sharp. The strata are affected by a large number of faults of small throw. One extensive fault involving a probable displacement of several thousand feet is indicated, mainly on physiographic evidence. The range of hills rising within Matanuska Valley and extending in an east-west direction from Kings to Tsadaka Creek represents an upheaved fault block. Between Tsadaka and Eska creeks this range consists of a great mass of conglomerate, 1,000 feet thick, with a gentle dip slope toward Mata-

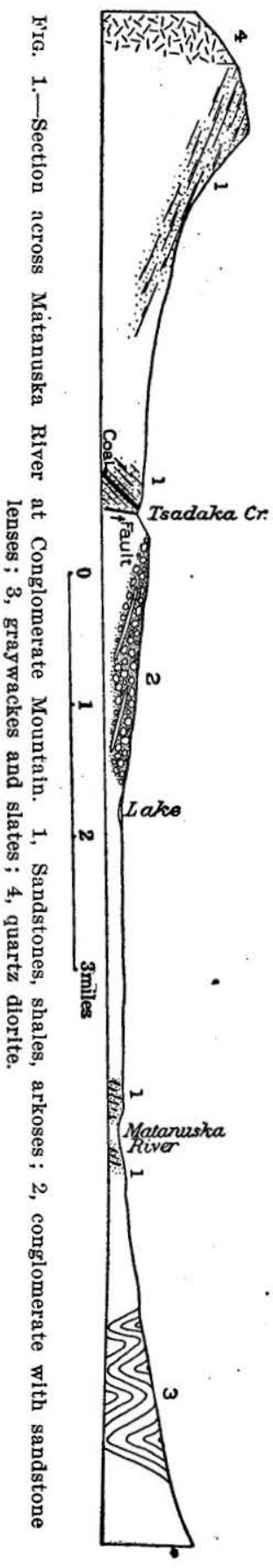
nuska River and a steep scarp toward the north (see fig. 1). During the 
uplifting of this block, differential movement has taken place within it, producing a series of nearly parallel faults, and the southern slope of the range descends to the level of the valley by a succession of steplike scarps. On the very brink of the northward-facing scarp of the range the differential movement has produced small fault troughs, within which lie small inclosed lakelets. (See Pl. IV, A.) These features are shown with great clearness on the topographic map. The recognition of this fault is of some economic importance, in that it indicates the limit of the available coal.

\section{DESCRIPTION OF THE COAL.}

The bituminous coal field of lower Matanuska Valley may be divided into two districts, the eastern and the western. Under the first may be included the coals of Kings and Chickaloon creeks and those on both sides of Matanuska River in the vicinity of Chickaloon Creek; under the second, the coals of Tsadaka and Eska creeks.

\section{EASTERN DISTRICT.}

Martin ${ }^{a}$ reports in regard to the eastern district:

The coal in this area all possesses about the same physical characteristics, and, as will be seen by the analyses, the variation in chemical composition is not great and supports this grouping. It has the ordinary properties of most bituminous coal. It is soft and fragile, but often without any well-defined planes of fracture. It burns with a short flame and a small amount of smoke. and possesses distinct coking properties. The seams generally contain a large amount of impurities, both in the form of thick partings of shale and as thin bands of shale and bone. Many of these can be separated in mining. The coal is soft and friable, and much of it will not stand severe handling without crushing. Pyrite is present both as balls and as scales, but not ąbundant. The friable character of the coal is not a great detriment when it is considered that much of it will probably have to be crushed and washed (especially for coke making), and that the coal when used for steam or heating will cake as soon as put in the furnace, so that there will consequently be little or no loss through the grates.

a Op. cit., p. 19 . 


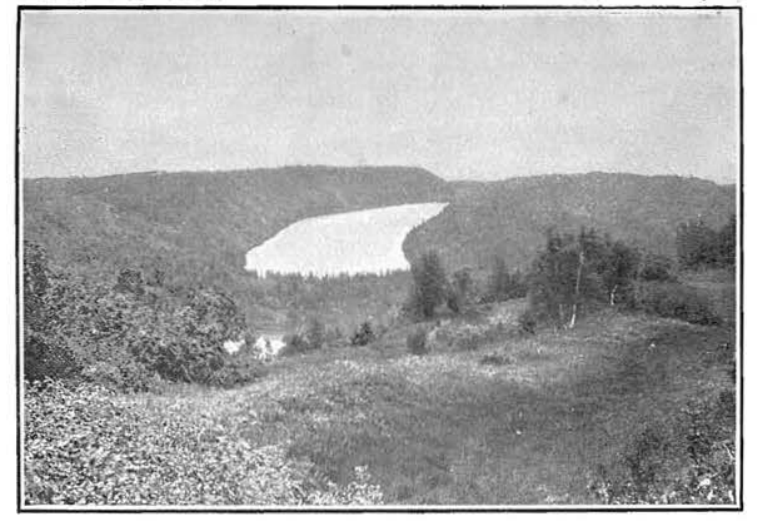

A. LAKE IN FAULT BLOCK, CONGLOMERATE MOUNTAIN.

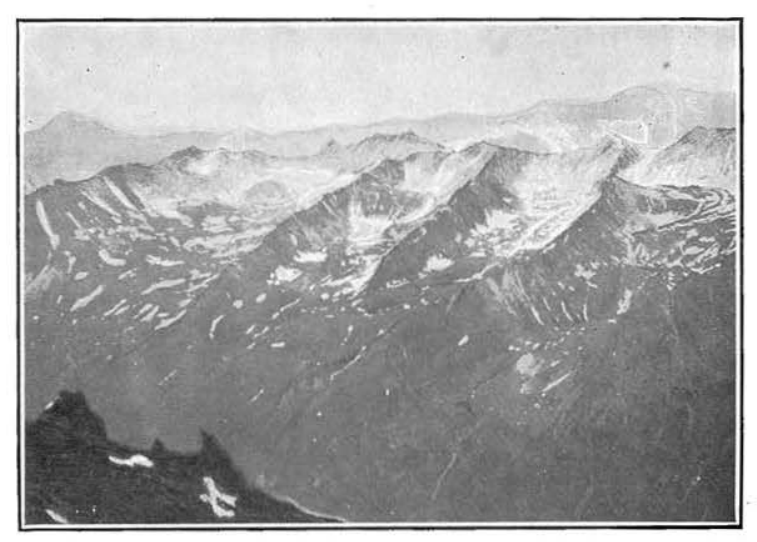

C. RUGGED TOPOGRAPHY DUE TO ALPINE GLACIATION.

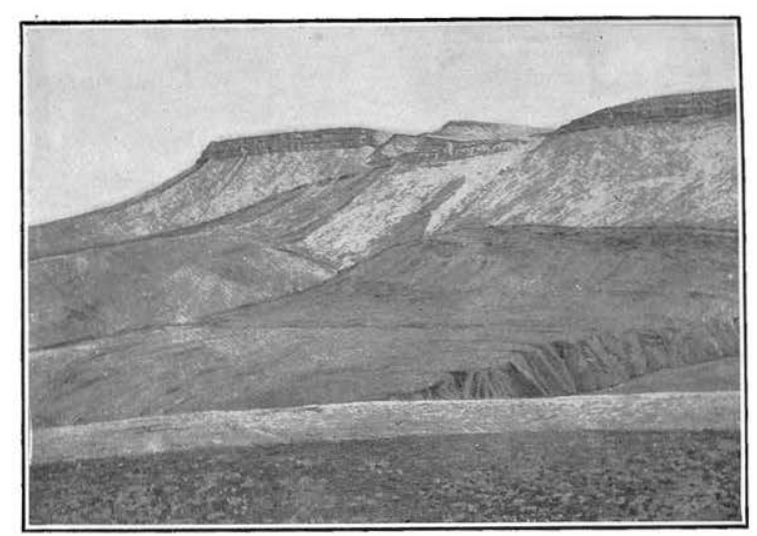

B. LIMESTONE AT HEADWATERS OF BILLY CREEK (NOTE FAULT).

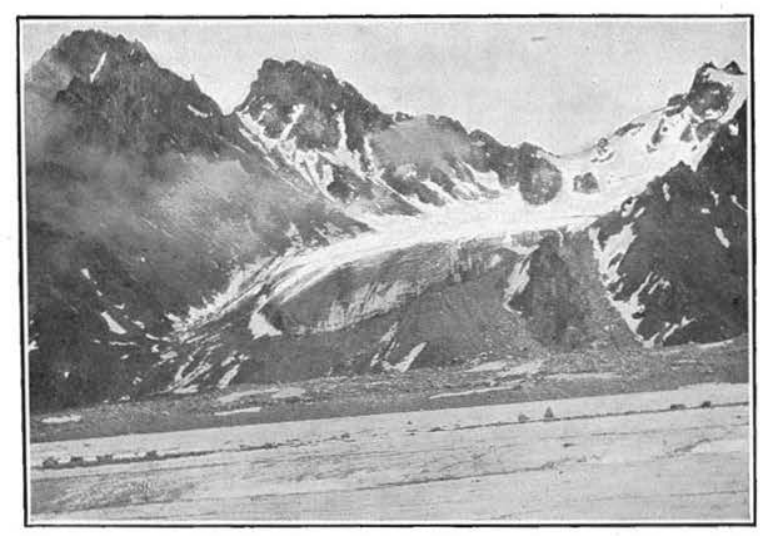

D. TRIBUTARY RECEDING FROM TRUNK GLACIER. 

'The following sections were obtained by Martin on the south side of the Matanuska near the mouth of Chickaloon Creek:

Section of coal beds on south bank of Matanuska River, 3 miles above the mouth of Chickaloon Creek.

Gray shale

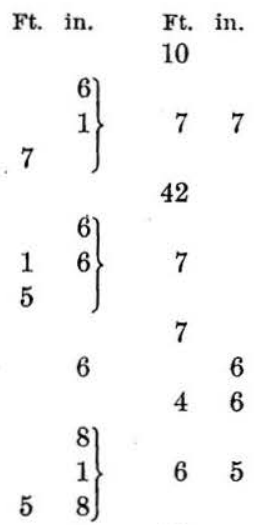

20

Soft gray shale

Concealed to river.

Strike N. $36^{\circ}$ E. (magnetic), dip $44^{\circ} \mathrm{SE}$.

Section on north bank of Coal Creek; elevation, 1,010 feet.

Soft dark shale

Coal $b$

Parting.

Coal $b$

Coal $b$

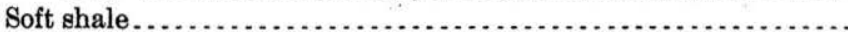

Strike N. $64^{\circ}$ E., dip $70^{\circ}$ SE.

Section on north bank of Coal Creek, 500 feet upstream from section given above.

Intrusive sheet and coke

Ft. in. 5

Coke

Intrusive sheet with coke

Shale.

Coal $c$

Shale.

Coal $c$

Shale.

Coal

Soft shale floor.
10

t. in.

A section on Coal Creek, one-half mile above the lower coal, shows coal about 6 feet thick, with a strike N. $60^{\circ}$ E. and a dip of $55^{\circ} \mathrm{NW}$.

a Included in samples Nos. 7 and 8; see analyses, p. 60.

${ }^{b}$ Included in samples Nos. 9 and 10 ; see analyses, pp. 60, 62.

- Included in samples Nos. 11 and 12 ; see analyses, p. 60. 
The following sections were measured on Chickaloon Creek:

Condensed section of coal-bearing rocks on Chickaloon Creek.

1. Shale with many thin iron-ore bands

Ft. in.

3. Coal with some bone and shale (see below) -

4. Coal with some shale (see below)

5. Shale and sandstone (horse)

6. Coal with some shale (see below) - 9

7. Shale and sandstone-_-_._- 37

8. Coal, impure and somewhat coked._._. 56

9. Shale and sandstone

10. Diabase sill with local occurrence of natural coke on top_______- 11

11. Coal and coke with impurities in an irregular distorted mass__._._- 15

12. Concealed _._._._._. not over 100

13. Shale -

14. Coal with some shale

15. Shale -

16. Coal with some shale

17. Shale and sandstone-_-_. 88

18. Coal with bone and shale__- 10

19. Shale -- 41

20. Coal (varies from $1 \mathrm{ft} .8 \mathrm{in.}$ to $3 \mathrm{ft} .7 \mathrm{in}$ )

21. Shale with some sandstone, iron ore, and volcanic beds, and a few

thin beds of coal and coke.

Section at bend of Chickaloon Creek, one-half mile above Watson's camp, show, ing details of beds 2 to 6 in condensed section.

Black shale

Ft. in. Ft. in.

Coal.

Coal, bony.

Shale

Coal

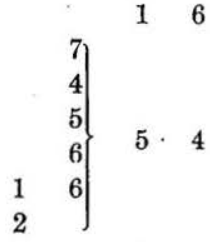

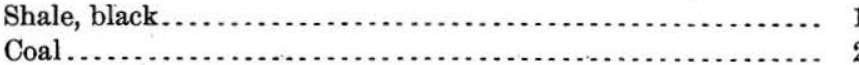

Concealed

Shale.

Coal

Shale

Coal.

Shale.

Coal 2

Shale and sandstone (horse).

Coal.

Shale, with coal stringer 3

Coal.

Shale

Coal

Shale

Coal

Shale

Coal

Shale. 
.In addition to the sections measured by Martin on Chickaloon Creek the following measurements were made in the tunnels opened at Watson's camp (fig. 2).

The sections are from the face outward; the thicknesses are recalculated for dip. The change in direction of dip which is evident between tunnel $\mathrm{D}$ and those farther east $(\mathrm{C}, 3,2 ; \mathrm{B}$, and $\mathrm{A})$ may possibly be explained by the presence of an anticlinal axis that passes westward from the anticlinal fold at tunnel No. 1, or possibly by irregularities in beds representing the south side of such an anticline.

It has been difficult to correlate the several beds within these tunnels because of striking irregularities in their thickness. The bed 16 feet 7 inches thick in tunnel $\mathrm{A}$ is undoubtedly the same as the bed 17 feet 3 inches thick in tunnel B.

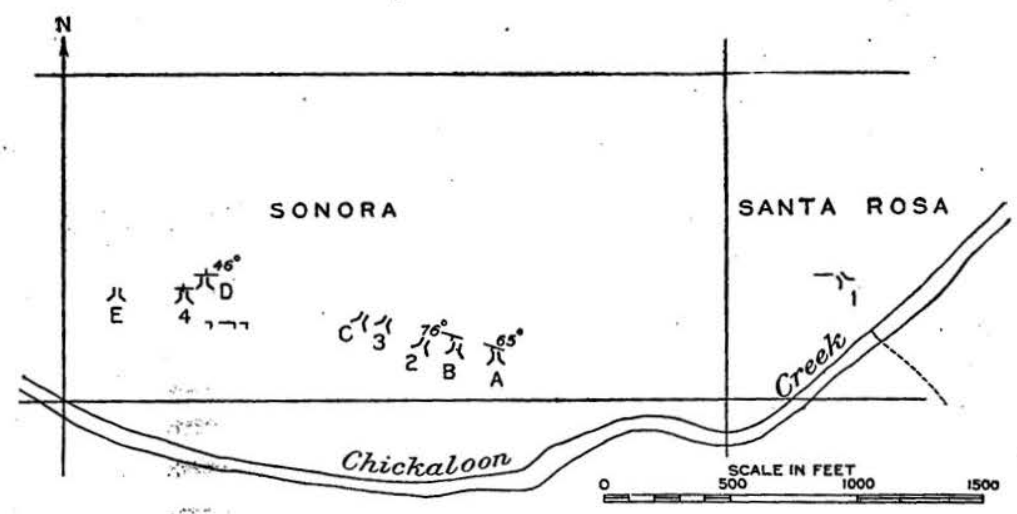

Fig. 2.-Sketch showing location of Chickaloon tunnels.

A drift frow tunnel B has been run to tunnel 2, which correlates the outermost seams of tunnel B with those at the face in tunnel 2.

The apparent lack of continuity in a number of the smaller seams in these tunnels may be explained either by local pinching out or by faults of small throw. The rocks in the near vicinity are closely folded, and faulting, with the added difficulties of mining which it incurs, should be expected.

\section{Section in tunnel A, Chickaloon Creek.} Ft. in. Ft. in.

Coal

Bone and coal.

Coal Shale

Coal.

Bone and shale

$$
\text { Coal. }
$$
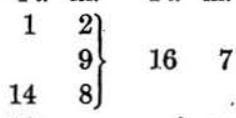

Shale.

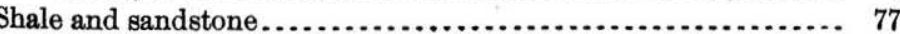

Strike N. $70^{\circ}$ W., dip $65^{\circ}$. 
Shale

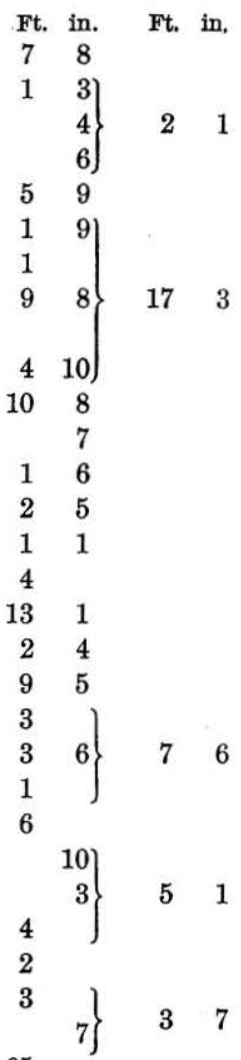

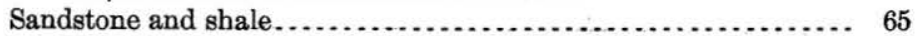

Strike N. $75^{\circ}$ W., dip $76^{\circ} \mathrm{S}$.

Section in tunnel No. 2, Chickaloon Creek.

Coal

Bone

Ft. in. Ft. in.

Coal.

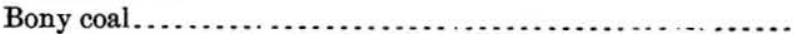

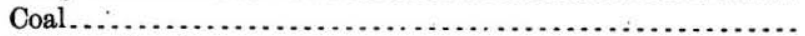

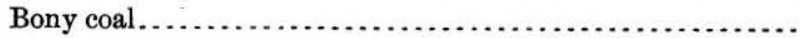

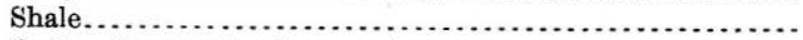

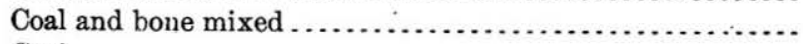

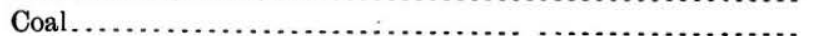

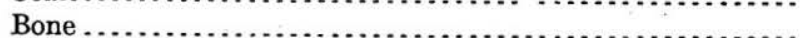

Coal. . . . . . . . . . . .

Shale

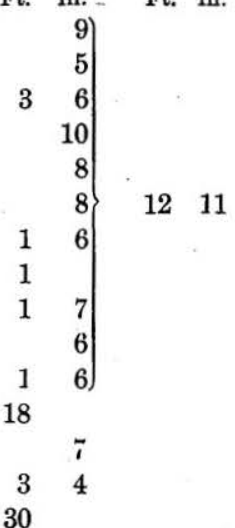


Section in tunnel No. s, Chickaloon Creek.

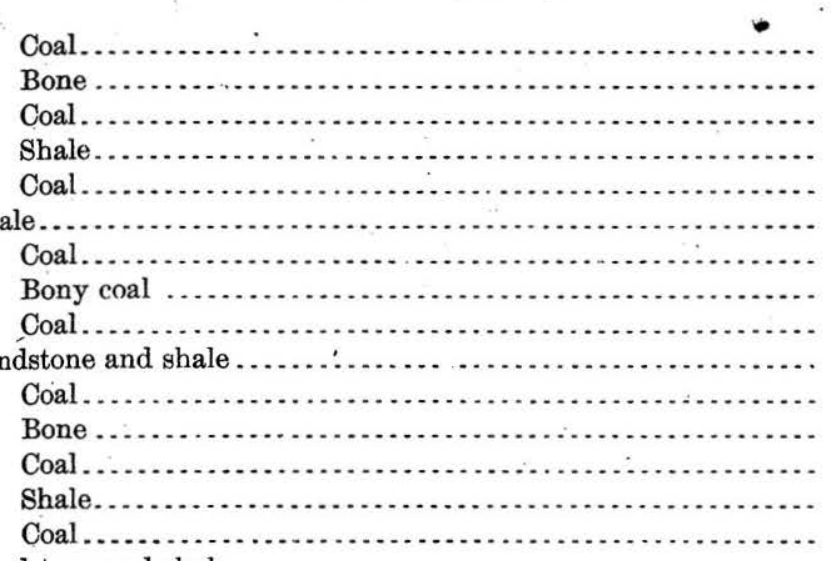

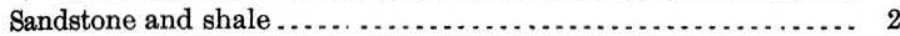

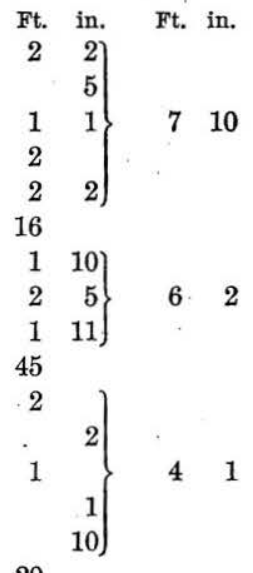

Section in tunnel C, Chickaloon Creek.

Coal

Shale and coal $\left.\begin{array}{l}2 \\ 2\end{array}\right\} \quad 4$

Sandstone and shale. 41

Section in tunnel D, Chickaloon Creek.

Crushed coal Ft. in. Sandstone and shale 26

Crushed coal _..._.

Sandstone and shale

Dip $46^{\circ} \mathrm{N}$.

Section in tunnel E, Chickaloon Creek.

Coal Ft. in. Ft. in.

Bone 15

Coal

Bone 110

Coal.

Crushed shale and coal

Coal.

Sandstone and shale. 18

On Kings Creek, $7 \frac{1}{2}$ miles above its junction with the Matanuska, coal seams are cut by the creek. They were measured on both sides by Martin and the writers. 
Section in tunnel on east bank of Kings Oreek, 100 yards above upper bridge.

Dense, impure coke.

Bony shale.

Coal.

Shale.

Coal.

Bone

Coal

Bony coal

Coal.

Hard shale.
Ft. in. Ft. in.

$5 \quad 5$

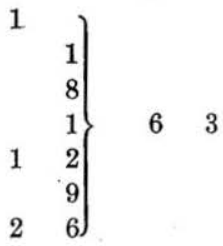

Section in open cut, 10 feet south of last opening.

Coal (no cover)

Shale

Coal

Soft impure coal

Coal

Shale

Coal

Shale and coal

Coal

Hard shale floor.

Section on Kings Creek at the upper bridge, west side.

Bone and coal

$$
\left.\begin{array}{rrrr}
\text { Ft. in. } & \text { Ft. } & \text { in. } \\
1 & 7
\end{array}\right\} \quad \begin{array}{rr}
2 & 2
\end{array}
$$

Clean coal

Concealed short distance.

Crushed coal with lenses of bone ...................... $5 \quad 7$

Shale

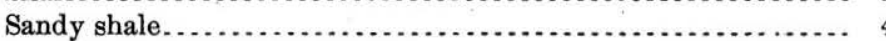

Coal

Bone

Coal............................................ 210

Coal and bone ................................... 8$\}$

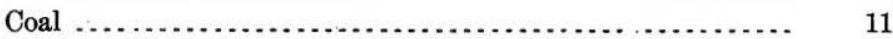

Bone ..........................................

Coal .............................................. 2

Strike N. $42^{\circ}$ W. (magnetic), dip $42^{\circ} \mathrm{NE}$.

Except the upper 2 feet 2 inches of coal, the section corresponds to that of Martin.

A short distance upstream from the exposure on the east side the sandstone beds are considerably disturbed. Folding or faulting, or possibly both, have occurred. 
The writers were not able to visit the coal on Young Creek. Martin says:

The coal on Young Creek is of intermediate character between that on Kings and Chickaloon creeks and south of the Matanuska and that in the west end of the field on Eska and Tsadaka creeks. It is reported that one or more seams of workable thickness have been found, but the following is all that was seen by the writer :

Section on west bank of Young Creek; elevation, 1,585 feet.

\begin{tabular}{|c|c|c|c|}
\hline & Ft. & in. & Ft. \\
\hline---- & & & 10 \\
\hline Sandstone - & & & 2 \\
\hline Shale - & & & 4 \\
\hline Sandstone & & & 1 \\
\hline Shale & & & 4 \\
\hline Coal $a$ - & 1 & & 1 \\
\hline Shale - - & & & 15 \\
\hline Coal & & 6 & \\
\hline Shale with sandstone bands & & & 15 \\
\hline Sandstone - & & & 1 \\
\hline Shale _- & & . & 10 \\
\hline
\end{tabular}

Strike N. $15^{\circ}$ E. (magnetic), dip $20^{\circ} \mathrm{NW}$.

WESTERN DISTRICT.

The coal of what has been termed the western district-that occurring on Tsadaka and Eska creeks-is a bituminous coal of low grade. Its physical properties are much the same as those of the coals farther east. Most of it is bright and hard, though dull, shaly bands are numerous. On Eska Creek the following sections were measured :

Section on west bank of Eska Creek; clevation, 875 feet.

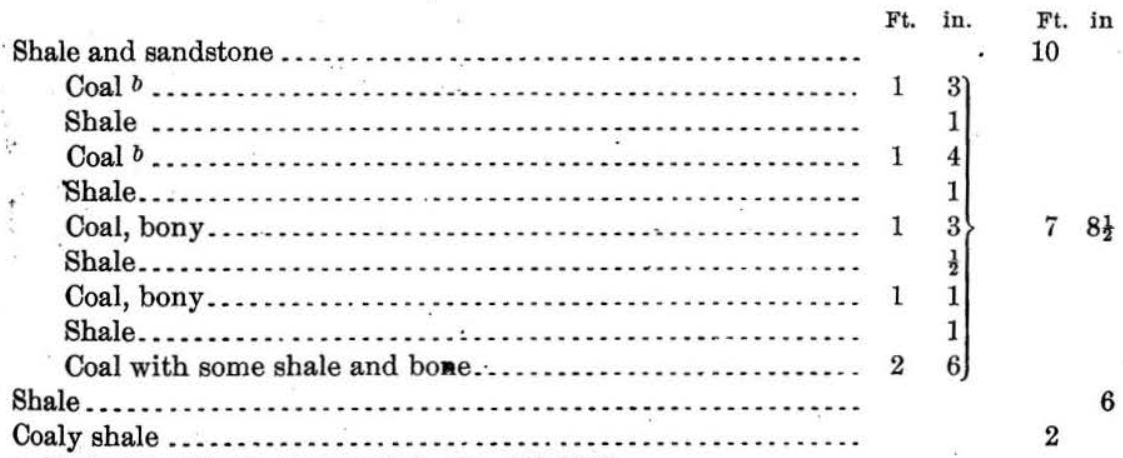

Strike N. $30^{\circ}$ E. (magnetic), dip $44^{\circ} \mathrm{NW}$.

${ }^{a}$ Included in sample No. 17 ; see analysis, p. 60

${ }^{\circ}$ Included in sample No. 18 ; see analyses, pp. 60,62 . $13070-$ Bull. $327-07-4$ 
Section on west bank of Eska Creek, about 300 feet farther up.

Shale roof. $\quad$ Ft. in,

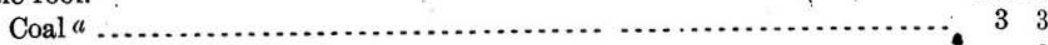

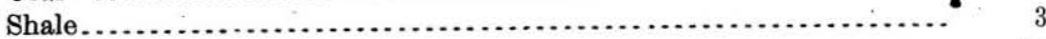

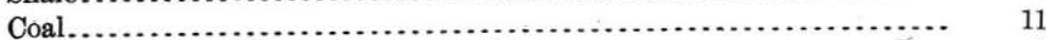

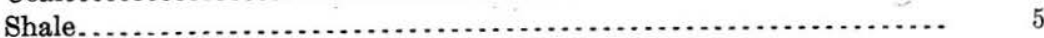

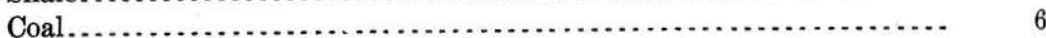

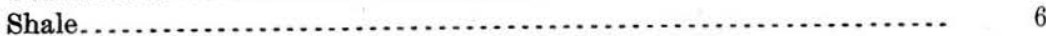

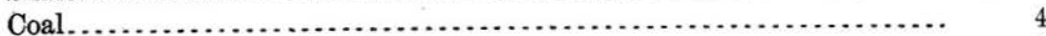

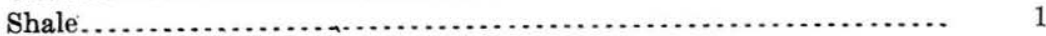

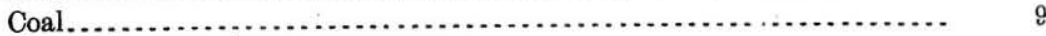

Soft black shale.

Dip NW.

Section on Eska Creek, about 600 feet above lower section.

Shale and sandstone. Ft. in.

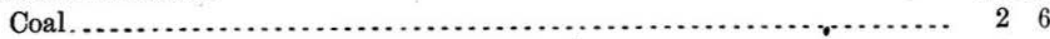

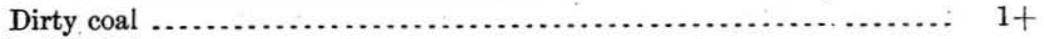

Dip $32^{\circ}$ SE.

Section in bluff on west bank of Eska Creek; elevation, 1,030 feet.

Sandstone

Ft. in.

Coal

2

Shale

Coal.

2

근 15

Shale

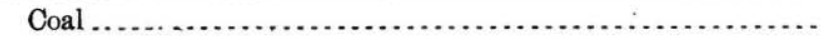

3

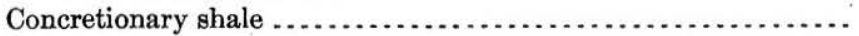

Black shale

Coaly shale

Coal, shaly

Coal

Shale with some coal

Coal

Shale.

Coal

Shale

Coal

Shale

Coal

\section{3}

Shale

Coal

Shale.

Coal.

Shale

Strike N. $40^{\circ}$ W. (magnetic), dip $40^{\circ} \mathrm{sW}$.

$\left.\begin{array}{ll} & 6 \\ & 9 \\ & 8 \\ 1 & 1 \\ 1 & 4 \\ 1 & \\ 1 & \\ 2 & \\ 1 & \end{array}\right\}$

A fault cuts the bluff in which this section was measured. The coal was measured above it. Below it the strike is northeast and dip southeast. 
On Tsadaka Creek a section near the upper end of the gorge at an elevation of 700 feet showed the following:

Section of coal near upper end of Tsadalia Creck gorge: clevation, roo fect.

Fissile black shaie

Ft. in. Ft. in.

Carbonaceous shale.

Sandstone

Coal

Sandstone

Bright coal

Shale

Bright coal .

Dull coal

Shale.

Dull coal

Shale

Strike N. $20^{\circ}$ W. (magnetic), (dip $24^{\circ} \mathrm{NE}$.

About 100 yards below the upper cabin the following section was exposed :

Section 100 yards below upper cabin, Tsadalia Creck.

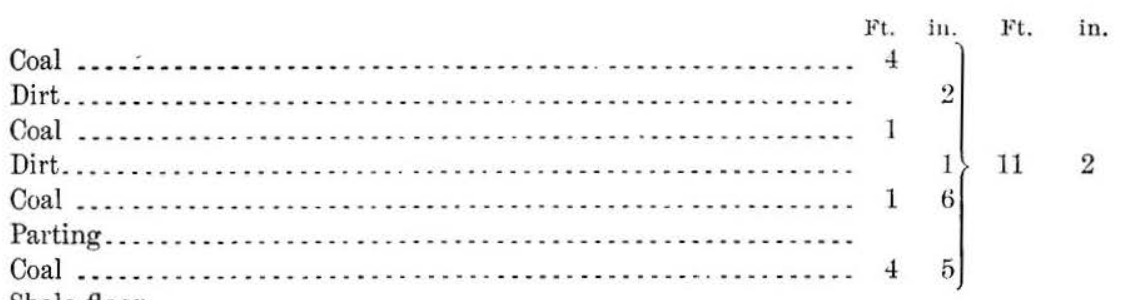

Shale floor.

The seam strikes $\mathrm{N} .80^{\circ}$ E. and dips $45^{\circ}$ N. A strike fitult dipping $80^{\circ} \mathrm{S}$. can be seen crossing the bed, with a throw of about 5 feet. An eighth of a mile downstream from this exposure a sharp syncline crosses the creek, with axis striking about S. $70^{\circ}$ E. and pitching steeply to the west.

A short distance farther downstream coal beds are exposed, striking N. $70^{\circ}$ E. and dipping $60^{\circ} \mathrm{N}$. At this locality the following section was measured :

Section one-cighth of a mile belou mpuer cabin, T'sadalia crect:

Shale and sandstone roof :

Dirty coal

Shale.

Sandstone nodules.

Bone and coal

Bone.

Coal

$\left.\begin{array}{rrrr}\text { Ft. } & \text { in. } & \text { Ft. } & \text { in. } \\ & 7 & & 7 \\ 3 & & 3 & \\ 1 & & 1 & \\ 1 & 3 \\ & 1 \\ & 3\end{array}\right\} \quad \begin{array}{ll}1 & 7\end{array}$




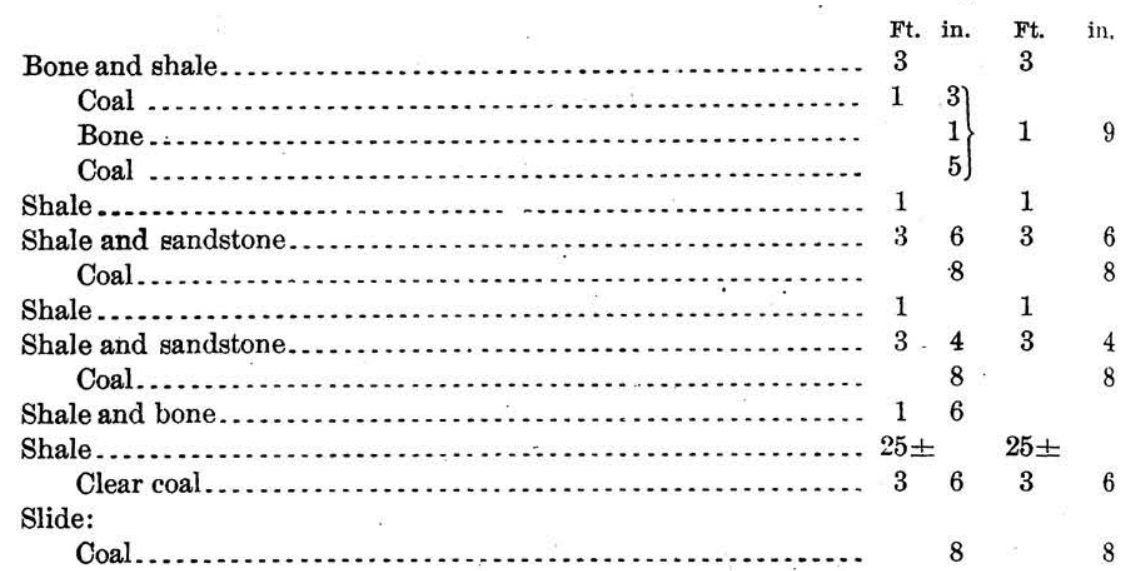

Up Tsadaka Creek and along the ridge on its southern side sandstones may be observed dipping southeast, which is a direction opposite to that of the beds just described. Still farther east conglomerate beds dip to the southwest. These conglomerate beds seem to owe their elevated position to a series of block faults passing in a general northeast and southwest direction, and the Tsadaka Creek coal is probably cut off to the east. It seems probable that Eska Creek coal is separated by these faults from that of Tsadaka Creek.

It will be noted that faulting or folding is present at nearly all the localities above described. Such conditions will make the cost of mining higher than it would be if the beds were less disturbed.

\section{ANTHRACITE RIDGE FIELD.}

GEOLOGY.

The most promising exposures of anthracite examined during the season were seen along the southern flank of Anthracite Ridge, between Boulder and Hicks creeks. The geology of this locality is somewhat complex. The western extremity of the ridge is formed by a large mass of augite dacite and brown porphyry. This latter appears to be intrusive into a series of interstratified sandstones and shales striking N. $35^{\circ}$ E. (magnetic) and dipping vertically. Associated with them is a large accumulation of andesitic amygdaloids and pyroclastics, of somewhat chloritized aspect. At the base of the ridge along the trail, however, cross-bedded gritty sandstones, apparently belonging to the Kenai formation, are exposed, striking $\mathrm{N}$. $75^{\circ} \mathrm{E}$. and dipping $15^{\circ} \mathrm{S}$. Some sills of coarse ophitic diabase, 50 feet and more in thickness, are intercalated between them. These observations indicate that the western extremity of the ridge is marked by a line of faulting along its base. And as marine fossils of Mesozoic age have been found on Anthracite Ridge, it has been 
assumed by Martin that an eastward extension of this fault determines the boundary between the Kenai and the Mesozoic rocks. Martin obtained a few fragmentary fossils, partly from the summit and partly from an elevation of 3,450 feet on the southern flank of the ridge. These indicated a horizon as low as the Middle Jurassic or as high as Upper Cretaceous. From the northern flank the writer obtained a single form, concerning which Stanton reports: "Inocercmus cf. lucifer Eichwald. This species occurs in the lowest part of the Enochkin formation (Middle Jurassic) at Snug Harbor." It is thus plain from the faunal and lithologic evidence that lower Middle Jurassic rocks are present on Anthracite Ridge, especially in the western end as approached from the Boulder Creek side.

Farther east, along the numerous small creeks which rise on Anthracite Ridge, it is found that the dip of the strata, which is nearly horizontal in the floor of the valley, gradually steepens as the flank of the ridge is approached. The beds become folded into anticlines and synclines, which are more closely crowded together toward the summit of the ridge. Locally the limbs of the anticlines have been doubled together. Thick sills of coarsely crystalline diabase are prevalent, especially along the middle portion of the ridge, and heavy dikes, attaining a maximum thickness of 500 feet, cut across the strata. Their energetic contact action in baking the adjoining shales has already been referred to. Moreover, their presence seems to be favorable to the anthracitic character of the coal. On a creek a few miles east of Purinton Creek, at an altitude of 3,100 feet, the stream banks show a 50 -foot sill of diabase, about 10 feet stratigraphically above a coal bed. The sandstone between the coal and the diabase, though elsewhere yellow, is black with material coating the cement between the quartz grains and in some places even invading the grains themselves. This suggests an impregnation of the sandstone during the distillation of the coal by the heat of the intrusive. The coal of this exposure is a fine lustrous anthracite. Higher up the same creek, near the summit of the ridge, a number of coal beds of bituminous character are exposed. ${ }^{a}$ No diabase intrusives are present in the immediate vicinity, but folding of a closely appressed character has affected the strata.

In the roof of an anthracite bed exposed in a creek somewhat west of Purinton Creek a few fragments of netted-veined leaves were found. Knowlton reports on these as follows: "6 A. K. 244. Matanuska Valley. Juglans nigella? Heer, no margin preserved. It looks like a Kenai dicotyledon, and not like any Cretaceous species known to me." 
The evidence from these plant remains shows, then, that at least this portion of the anthracite is probably of Kenai age, and that it does not occur in rocks of Middle Jurassic age, which are known from their marine fauna to be present in close vicinity and possibly to be infolded to some extent with the Kenai rocks, or irregularly faulted against them.

From a consideration of the structural and floral evidence it appears to the writer that the coal of this field is chiefly of Kenai age, and that its anthracitic character is due to the large amount of heat furnished by the unusually abundant diabase intrusions. The Anthracite Ridge field represents, according to this view, a portion of the Tertiary coal-bearing area which has been more highly affected by the heat of eruptive rocks. The amount of anthracite appears to be limited, and will not warrant an extensive outlay of capital for its exploitation. In addition, the complex folding of the strata and the presence of massive diabase injections will seriously increase the difficulties of mining.

\section{DESCRIPTION OF THE COAL.}

Martin has described the coal as follows:

This coal has the ordinary physical characteristics of most good coal of this kind. It is heavy, firm, hard, and not much fractured for surface coal, and has a high luster. Pyrite was noticed. The seams are not much broken by small partings of shale and bone.

Two sections were measured by Martin: One at an elevation of 3,410 feet on the south bank of Purinton Creek showed 38 feet of clean, solid coal, both roof and floor being concealed. (see analysis No. 1, pp. 60, 62, which represents the entire thickness as measured). Martin says:

At this point the strike is $\mathrm{N} .40^{\circ} \mathrm{E}$. (magnetic) and the dip is $10^{\circ} \mathrm{NW}$., or into the mountain. The rocks in the vicinity are chiefly graywacke and sandstone and show considerable variation of strike and dip. A short distance downstream is a good-sized mass of dfabase occupying the axis of an anticline, which is in ather places restricted by a fault. The anthracite is probably restricted to a zone along the face and in the mountains which is cut off from the valley plateau by a fault following the base of the mountains. Black streaks that are probably coal could be seen high up on the face of the mountain and could be followed by the eye for sereral miles. $* * *$

About a mile northeast of the locality above described, at an elevation of 3,460 feet, a coal section gave the following measurements: 
Section of coal on slope of Talkeetna Mountains.

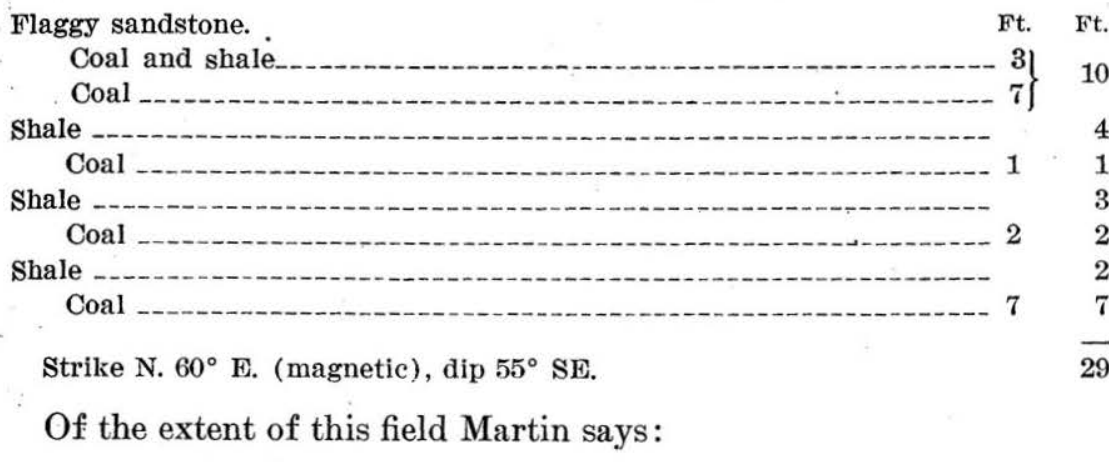

The area of anthracite was not estimated by the writer, and the amount available for economic mining and shipment may possibly not be sufficient to justify the necessary expenditures.

In addition to the sections of coal measured by G. C. Martin on Anthracite Ridge, the following sections were obtained somewhat farther east:

\section{Section of coal on Anthracite Ridge, altitude 3,100 feet.}

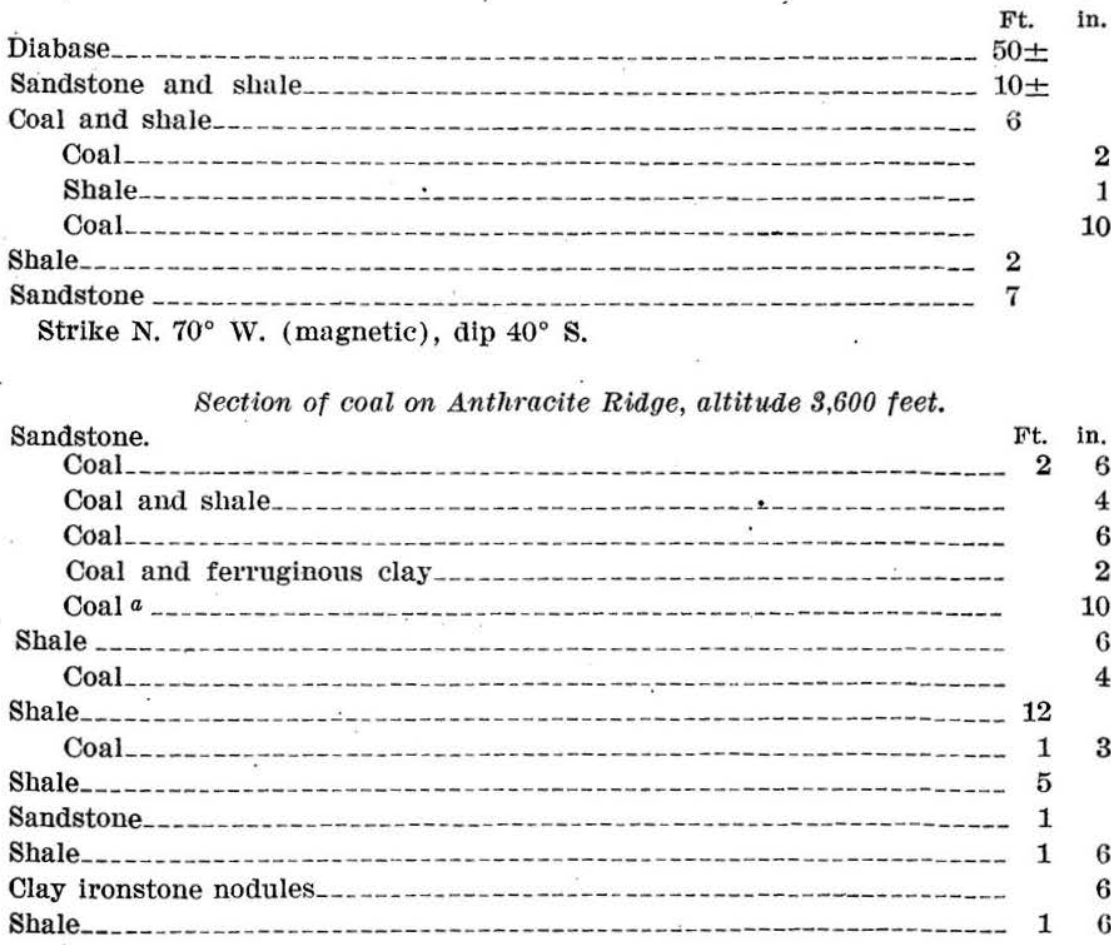

${ }^{a}$ See analysis No. 22 in table of ultimate analyses, p. 62. 


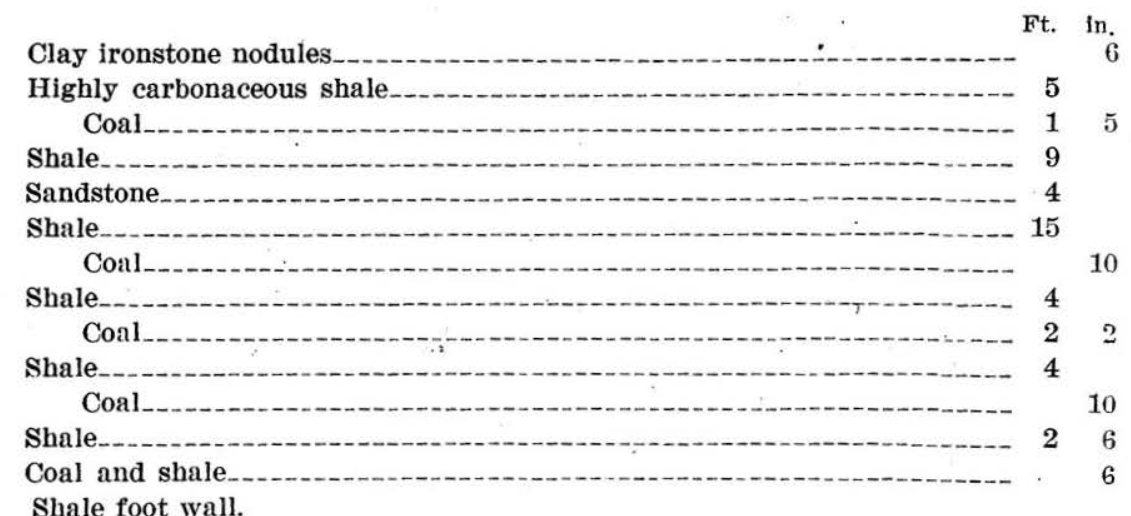

Strike N. $80^{\circ}$ E. (magnetic), dip $34^{\circ} \mathrm{S}$.

A syncline of coal 3 feet thick, cut off by a heavy diabase dike, is exposed in a small creek west of Purinton Creek (as shown in fig. 3).

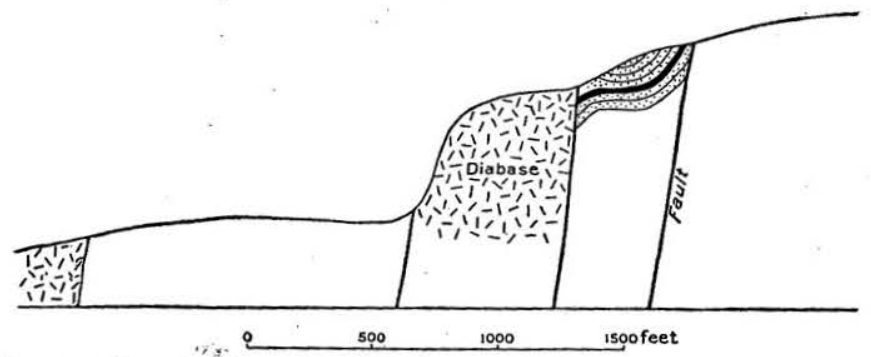

FIG. 3.-Cross section showing relation of anthracite to intrusive diabase near Purinton Creek.

\section{NORTHEASTERN FIELD.}

The coal-bearing rocks of this field include an area of about 500 square miles. Coal is found at various localities, but never in thick beds, the best discovered having a thickness of 3 feet. The rocks are of Jurassic age and from fossil evidence are divided into a Middle and an Upper Jurassic series. The character of the coal appears in a general way to be in accordance with this separation, i. e., the older rocks carry bituminous coal, and the younger, coal of a lignitic character.

The Middle Jurassic rocks generally are severely shattered and crushed, or sheared and slickensided, and as a rule present a decidedly unfavorable appearance for the presence of workable seams of coal. Locally the strata are closely folded, as on Billy Creek (see fig. 4), where the coal has developed a strong cleavage and has assumed a semianthracitic character. That the high-grade coal is restricted to such belts of sharp deformation is rendered probable by 
the fact that the rocks in the less disturbed areas are found to contain only fragments of carbonized wood and small stringers of lignite.

The Upper Jurassic strata lie in comparatively undisturbed attitudes, with prevailing low dips. Minor dislocations of the beds are of widespread occurrence. More extensive faulting is occasionally met with, as on Billy Creek, where faults of several hundred feet throw are revealed with diagrammatic clearness. Coal was seen at only two localities, on the head of Billy Creek and on the south fork of the Tyonek. At these localities the outcrops were obscured by mud and slide material, but the amount of coal represented was probably small. The coal found is a black lignite which checks on drying. Mendenhall reports thin beds of coal interstratified with the shales and sandstones along the south fork of the Nelchina.

\section{ADJACENT COAL FIELDS.}

Coal fragments are reported from Willow Creek. From Kashwitna River, at two points half a mile apart, and from Canoe Creek,

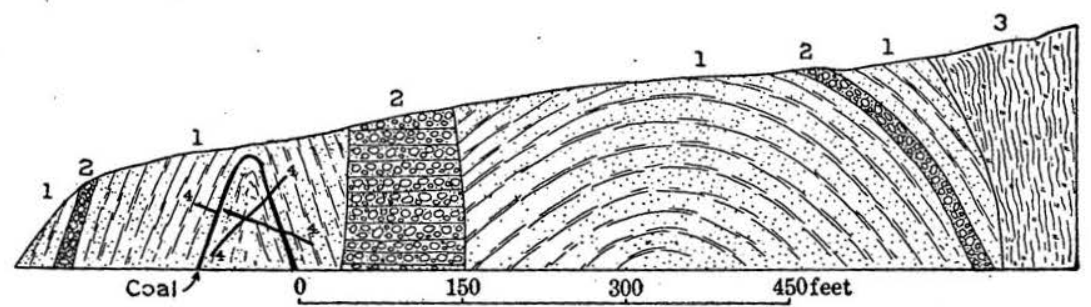

Fig. 4.-Section on Billy Creek. 1, Sandstone and shale; 2, conglomerate; 3, greenstone amygdaloids ; 4 , basalt dikes.

7 miles north, a bed of lignite 7 or 8 feet thick is reported. This bed lies nearly horizonţal and slopes very gently to the west. This appears to be an extension of the field of which Martin has compiled the following information: ${ }^{a}$

There appears to be a considerable area of coal or lignite in the Susitna Valley, in the vicinity of the mouth of the Talkeetna. Some of the exposures were seen by Eldridge, $b$ who describes them as follows :

"The third coal field along the main river, 4 to 10 miles above the Chulitna, appears in outcrops for a distance of 6 or 7 miles and is perhaps the exposed portion of an extensive area. The strata form bluffs 100 to 300 feet high, and consist of clays and sandstones-the former predominating-with coal seams from 6 inches to 6 feet thick. There are perhaps ten or fifteen coal beds exposed in the entire length of the outcrop. Their general dip is $5^{\circ}$ to $10^{\circ} \mathrm{SSE}$., with undulations. The thickness of the series exposed is perhaps 500 feet."

${ }^{a}$ Op. cit., p. 26.

a Eldridge, G. H., A reconnaissance in the Susitna basin and adjacent territory in 1898 : Twentieth Ann. Rept. U. S. Geol. Survey, pt. 7, 1900, p. 22. 
Other exposures in the same general district were described by Lieutenant Learned, who said: $a$

"As the party under my charge proceeded up the Susitna River, specimens of coal were found on the sand bars from time to time, but more plentifully as the forks were approached. On the way down the river an outcropping of coal was seen on the east fork of the Susitna River, about 2 miles south of the fork. The vein could not be measured, but as near as could be determined it was about 6 feet thick and of a poor quality.

"Upon entering the Talkeetna River coal was seen on the bars and banks, and the same coal was found in the Chunilna River. It was the main fuel used at the camp on the Chunilna River for about two months. The coal found there was a brown lignite of about the same grade as the best found in the vicinity of Tyonek. The vein was located first by Sergeant Yanert, and is noted on his map. It is about 6 miles above the mouth of the Chunilna, at the base of a cut gravel bank about 100 feet high. When seen by Sergent Yanert the water was clear and the vein could be traced across the river to the east bank. When I visited the vein the river was flooded and therefore very muddy. As near as could be determined by me the vein was 6 feet out of and fully as much more under the water, making it 12 feet thick, but Private Gamble, who had seen it in clear water, said it was at least 15 feet thick and perhaps much more, as it extended across the river, forming its bed, and there was no way of determining the thickness of that part forming the bed of the river. The vein is only slightly tilted, and comparatively easy to work if occasion should ever render it valuable. $* * *$ All of the coal found, when consumed, gave a fair amount of heat, but left a large amount of ashes. $* * *$ Sergeant Yanert reported that he found another large coal vein on the Chulitna River of about the same grade as the Tyonek coal. It is doubtful if the coal found will ever have any commercial value, except such value as it possesses for fuel in the vicinity, and even that will be small, because of the timber found in the same localities. Enough was ascertained to show that there is plenty of coal of an inferior grade along the Susitna River."

The Cook Inlet coal fields have already been described by various authors. All existing information was summarized in 1902 by Brooks, $b$ who gave complete references to the earlier publications.

There seems little doubt that lignitic coal-bearing strata border the western base of the Talkeetna Mountains from Cook Inlet at least as far as Chunilna River, as is indicated by the successive float and outcrops reported from Willow Creek, Canoe Creek, Kashwitna River, and Chunilna River. It seems probable that these exposures are of sediments of Eocene age and of the same series of beds that were seen at other localities by Eldridge. ${ }^{c}$

${ }^{a}$ Learned, Lieut. H. G., Reports of explorations in the Territory of Alaska, War Dept.. Adjutant-General's Office, No. 25, 1899, pp. 162-163.

${ }^{b}$ Brooks, A. II., The coal resources of Alaska: Twenty-second Ann. Rept. U. S. Geol. Survey, pt. 3 , 1902, pp. 543-546.

c Op. cit. 
ANALYSES AND TESTS.

CHEMICAL AND CALORIMETRIC TESTS.

The samples collected by Martin were (with the exception of No. 3) all taken in a uniform manner. They were obtained by making a cut across a fresh face of the coal from roof to floor, cutting down only the coal which would probably be loaded and leaving out such impurities as could be separated in the ordinary practices of actual mining. They are thus supposed to represent the quality of the coal which would be mined from these seams. The parts of each seam which went into the sample are indicated in the local sections. No. 3 was taken from only the best parts of the seam and impurities were rejected which could be separated in practice only by very careful treatment, such as in "screened and hand-picked" coal, or possibly by some mechanical process, or by washing. The object of this section was to show, by a comparison of analyses Nos. 2 and 3, what could probably be gained in practice by such careful separation of impurities.

The samples that Martin collected were all analyzed by F. M. Stanton at the United States Geological Survey coal-testing plant at St. Louis, Mo. The methods of analysis are described in the reports of this plant. ${ }^{a}$

The other analyses were gathered from a variety of sources. Nos. $4,8,10,12$, and 14 are based on duplicates of samples taken by Martin. The others are of varied character, some being fair representations of the seams and some random selections of the best coal.

The anthracite coal is represented by a single analysis (No. 1), which shows it (so far as this one outcrop is concerned) to compare favorably with some of the Pennsylvania anthracite.

Comparison of Matanuska and Pennsylvania anthracite.

\begin{tabular}{|c|c|c|c|c|c|c|}
\hline Coal. & Moisture. & $\begin{array}{l}\text { Volatile } \\
\text { matter. }\end{array}$ & $\begin{array}{c}\text { Fixed } \\
\text { carbon. }\end{array}$ & Ash. & Sulphur. & $\begin{array}{l}\text { Fuel } \\
\text { ratio. }\end{array}$ \\
\hline 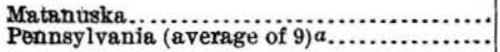 & $\begin{array}{l}2.55 \\
3.39\end{array}$ & $\begin{array}{l}7.08 \\
3.81\end{array}$ & $\begin{array}{l}84.32 \\
83.79\end{array}$ & $\begin{array}{l}6.05 \\
8.42\end{array}$ & $\begin{array}{r}0.57 \\
.59\end{array}$ & $\begin{array}{l}11.91 \\
22.33\end{array}$ \\
\hline
\end{tabular}

a Ashburner, C. A., Ann. Rept. Geol. Survey Pennsylvania, 1885, p. 313.

A sample from Anthracite Ridge taken by the writers during the season of 1906 is here of special interest. (See No. 22 in table of ultimate analyses.) It will be seen that the coal has a fuel ratio of only 1.90 , which places it in the bituminous class. The difference in

\footnotetext{
a Preliminary report on the operations of the coal-testing plant of the United States Geological Survey at the Louisiana Purchase Exposition, St. Louis, Mo., 1904: Bull. U. S. Geol. Survey No. 261, 1905, pp. 30-31. Report on the operations of the coaltesting plant of the United States Geological Survey at the Louisiana Purchase Exposition, St. Louis, Mo., 1904 : Prof. Paper U. S. Geol. Survey No. 48, 1906, pp. 174-192.
} 
P $\quad$

Proximate analyses of Matanuska coals.

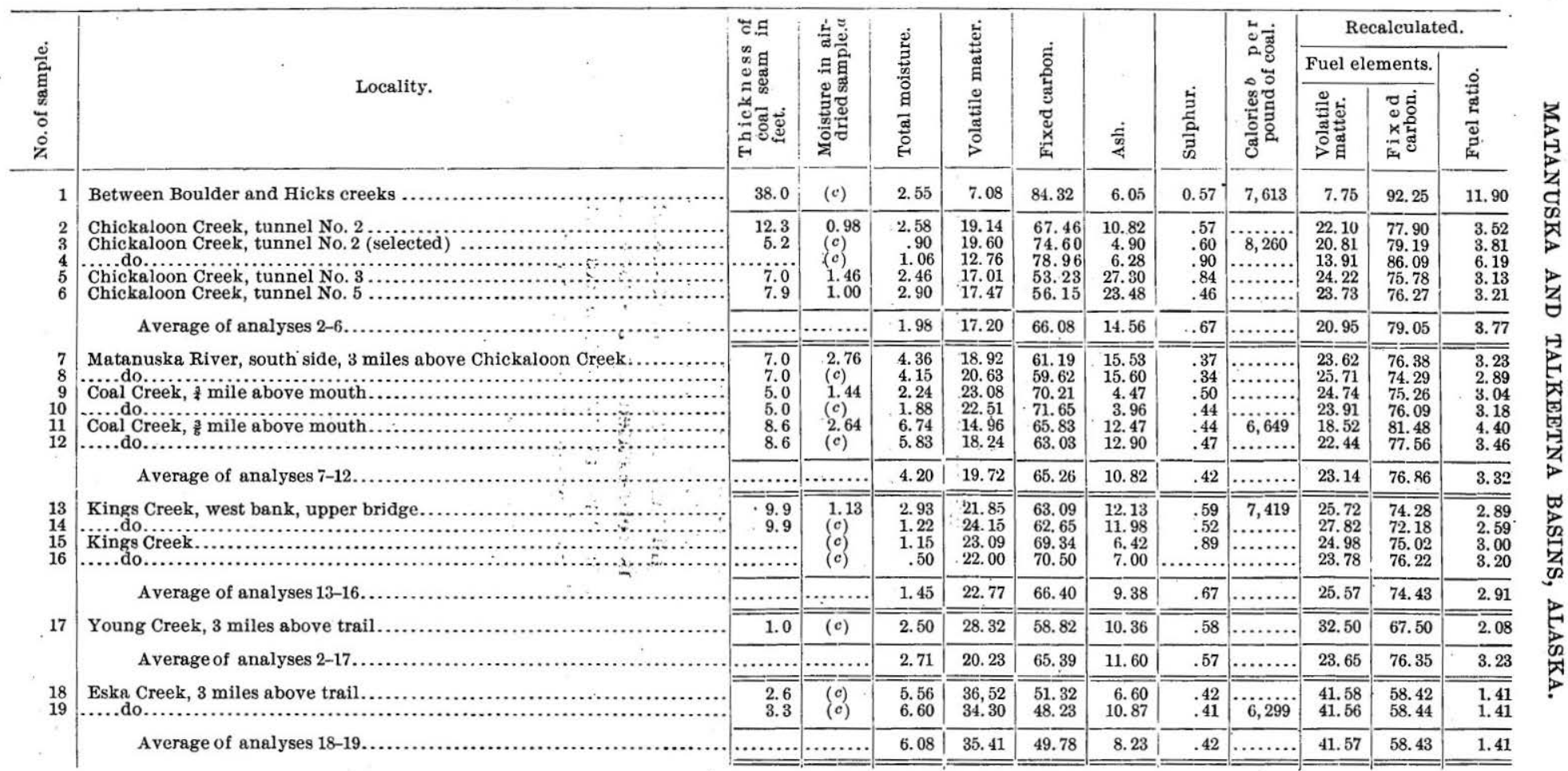




\begin{tabular}{|c|c|c|c|c|c|c|c|c|c|c|c|}
\hline 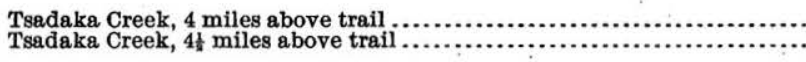 & $\begin{array}{r}6.0 \\
11.7\end{array}$ & $\begin{array}{l}(c) \\
5.45 \\
\end{array}$ & $\begin{array}{r}4.03 \\
10.05 \\
\end{array}$ & $\begin{array}{l}34.84 \\
36.05\end{array}$ & 49.81 & $\begin{array}{r}11.82 \\
5.00 \\
\end{array}$ & .38 & $|\cdots \cdots \cdot \cdot|$ & $\begin{array}{r}41.40 \\
42.44 \\
\end{array}$ & $\begin{array}{l}58.60 \\
57.56 \\
\end{array}$ & $\begin{array}{l}1.42 \\
1.36\end{array}$ \\
\hline $\begin{array}{l}\text { Average of analyses } 20-21 \ldots \ldots \ldots \ldots \ldots \\
\text { Average of analyses } 18-21 \ldots \ldots \ldots \ldots\end{array}$ & & & $\begin{array}{l}7.04 \\
6.56\end{array}$ & $\begin{array}{l}35.45 \\
35.43\end{array}$ & $\begin{array}{l}49.10 \\
49.44\end{array}$ & $\begin{array}{l}8.41 \\
8.32\end{array}$ & .32 & 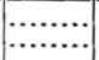 & $\begin{array}{l}41.92 \\
41.74\end{array}$ & $\begin{array}{l}58.08 \\
58.26\end{array}$ & $\begin{array}{l}1.39 \\
1.40\end{array}$ \\
\hline
\end{tabular}

$a$ Determined by drying in the open air until weight becomes constant.

$b$ A calorie is the, amount of heat necessary to raise the temperature of 1 pound of water $1^{\circ} \mathrm{C}$. It is equal to $1.8 \mathrm{British}$ thermal units. $c$ Not determined.

1-3, 5-7, 9,11, 13,17-21. Sampled by G. C. Martin. Analyses by F.M. Stanton, U. S. Geological Survey coal-testing plant, St. Louis, Mo.

15. Sampled by George Jamme. Analysis by C.C. Bogardus, Seattle, Wash. Published in Bull. U. S. Geol. Survey No. 259, 1905, p.170.

16. Sampled by Frank Watson. Analysis by William H. Stowell \& Co. Seattle, Wash. 
the quality of the coal is regarded as dependent on the presence of neighboring igneous rocks.

Analyses a of Matanuska River coals.

\begin{tabular}{|c|c|c|c|c|c|c|c|c|c|c|c|c|c|}
\hline \multirow[b]{2}{*}{ 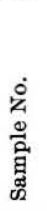 } & \multirow{2}{*}{ 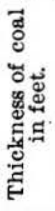 } & \multicolumn{4}{|c|}{ Proximate analysis. } & \multicolumn{6}{|c|}{ Ultimate analysis. } & \multicolumn{2}{|c|}{$\begin{array}{l}\text { Calorific } \\
\text { value. }\end{array}$} \\
\hline & & 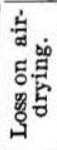 & 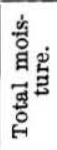 & 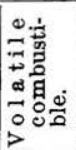 & 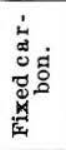 & 要 & 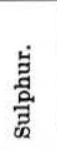 & 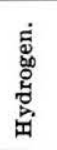 & हี & 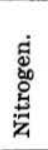 & 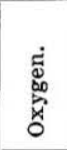 & 䒿 & 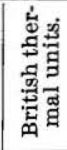 \\
\hline 1 & 38.0 & (b) & 2.60 & 5.26 & 86.15 & 5.99 & 0.57 & 3.07 & 84.30 & 1. & 4.94 & 7.586 & 13,655 \\
\hline 2 & 12.3 & 1. 60 & 2.55 & 16. 66 & 69.72 & 11.07 & .57 & 4.19 & & 1. & 6. 22 & 7,545 & 13,581 \\
\hline 3 & 5.2 & (b) & .99 & 19.03 & 75.19 & 4. & .60 & 4. 71 & & & 4. 52 & 8,205 & 14,769 \\
\hline 9 & 5.0 & .80 & 1.97 & 18. & 75.19 & 4. & 5 & 4.80 & & 1. & & 8,146 & 4,663 \\
\hline 13 & 9.9 & 1.80 & 2.68 & 20.69 & 64.72 & 11.91 & .59 & 4. 68 & 74. & .87 & 7.57 & 7,422 & 13,360 \\
\hline 18 & 2.6 & $(b)$ & 4. 74 & 34. & 54. & 6. & .42 & 5. & & 1. & 14. & 6,985 & 12,573 \\
\hline 19 & 3.8 & (b) & 5.00 & 33. & 50. & 10. & .4 & & 63 & & & & 11,408 \\
\hline 20 & 6.0 & (b) & 4. 75 & 32.6 & 50. & 11.9 & 3 & & 64. & & 17 & 6,428 & 11,570 \\
\hline 21 & 11.7 & 4.60 & 9.49 & 33.6 & 51. & 5.1 & .2 & 5. & 65. & 1. & 22 . & 6,445 & 11,601 \\
\hline 22 & .9 & $(b)$ & 2 & 30. & 50. & 9. & & 4.8 & 71. & 1.50 & 12.38 & 7,303 & 13,145 \\
\hline
\end{tabular}

a These analyses were made by F. M. Stanton on the same samples as those with corresponding numbers on $\mathrm{pp} .60,61$. The differences in proximate analyses are due to the fact that the samples dried somewhat in the months which elapsed between analyses, and that somewhat different methods of analysis were used (see Bull. U. S. Geol. Survey No. 290,1906 , pp. 29-30).

'Not determined.

The coals represented by analyses 2 to 17 are near the border line between semibituminous steam coals (as the name is generally used in the trade, but not according to Frazer's definition ${ }^{a}$ ) and bituminous coking coals. They are rather high in ash, but are otherwise of good quality. Analyses 5 and 6 bring the average ash abnormally high, but even aside from these most of the seams are so impure that mechanical separators or washing should be used to remove part of the impurities. The purer of these coals correspond very closely to the Crows Nest Pass (British Columbia) coal, ${ }^{b}$ which is the standard coking coal of western North America, and approximately to some of the coking coal of the East.

The bituminous coal of lower grade on Eska and Tsadaka creeks, which the analyses show to be intermediate between first-class bituminous coal and the lignite coals, should probably be called bituminous rather than lignite, its usual designation in the region. It is of about the same composition as the Franklyn, Black Diamond, and Renton (Washington) coal. It probably will not make good coke, but should serve well under stationary boilers, and possibly as a locomotive fuel and for other local uses. It should be especially well adapted to the generation of power by the use of producer gas in a gas engine.

a Rept. Geol. Survey Pennsylvania, vol. MM, 1879, pp. 144-145.

'Martin, G. C., Markets for Alaska coal : Bull. U. S. Geol. Survey No. 284, 1906, p. 29. 


\section{COKING QUALITIES.}

A rough test of the coking qualities of the coal from tunnel No. 2 on Chickaloon Creek (see p. 46) was made, during the summer of 1905 , by coking a large pile of coal under a covering of stones and dirt. The resulting coke was hard and firm and had a good ring and a good texture. The test showed conclusively that a satisfactory grade of coke can be produced.

\section{MINING CONDITIONS.}

No serious difficulties prevent the mining of these coals. The dips are so steep $\left(10^{\circ}\right.$ to $60^{\circ}$ on the anthracite, $18^{\circ}$ to $85^{\circ}$ in the east end of the bituminous area, and $20^{\circ}$ to $44^{\circ}$ in the west end of the bituminous area) that some method of stoping must be used. Miners who are accustomed to the steep dips in some of the coal mines of Washington and British Columbia will have no difficulty in this field. Drifts can be run from the level of some of the main streams, and enough coal found above drainage to supply the mines for some time. It will ultimately be necessary to resort to slope or shaft mining. These methods, or tunnels across the measures from the upper floor of Matanuska Valley, will probably have to be used on the anthracite very soon. But no operations should be undertaken in the anthracite area without thoroughly investigating the amount of workable coal, both by carefully exploring the surrounding country in search of outcrops and by testing the thickness and continuity of the seams by boring or other underground work. There is an abundant local supply of wood for building and mine timbering.

It will be necessary to wash or otherwise clean the coal from some of the seams. The percentage of ash can be reduced by washing from $10,12,15,23$, and 27 per cent to less than half and probably in some cases to a quarter of these figures. By washing tests at the coaltesting plant of the United States Geological Survey ${ }^{a}$ the percentage of ash was reduced as follows:

Percentage of ash in raw and washed coal.

\begin{tabular}{|c|c|c|}
\hline $\begin{array}{l}\text { Test } \\
\text { No. }\end{array}$ & $\begin{array}{l}\text { Raw } \\
\text { coal. }\end{array}$ & $\begin{array}{c}\text { Washed } \\
\text { coal. }\end{array}$ \\
\hline $\begin{array}{r}1 \\
2 \\
3 \\
4 \\
5 \\
6 \\
7 \\
8 \\
9 \\
10\end{array}$ & $\begin{array}{r}22.44 \\
13.40 \\
28.39 \\
13.81 \\
10.59 \\
9.99 \\
7.75 \\
25.05 \\
16.00 \\
15.22\end{array}$ & $\begin{array}{r}9.42 \\
7.16 \\
7.59 \\
6.22 \\
5.86 \\
6.33 \\
7.49 \\
8.14 \\
10.25 \\
10.28\end{array}$ \\
\hline
\end{tabular}

a Preliminary report on the operations of the coal-testing plant of the United States Geological 'Survey at the Louisiana Purchase Exposition, St. Louis, Mo., 1904 : Bull. U. S. Geol. Survey No. 261, 1905, pp. 60-73. 
GOLD.

Gold-bearing rocks are found over considerable areas in the region adjacent to Cook Inlet. A series of graywackes and slates, cut by small quartz stringers, occupies the eastern part of the Kenai Peninsula, forming the bed rock of the Sunrise mining district, extends - across Turnagain Arm, and may be seen in the valley of Knik River still farther north. The search for placer gold in rocks of this type is warranted, and discoveries of commercial value may possibly be made.

North of Matanuska River, on the southern margin of a granite mass, occurs a band of highly crystalline mica schist. It is closely folded and infiltrated with fine quartz stringers. The only productive placer thus far developed within the region is situated on this belt of schists. It is noteworthy that the igneous rocks, granitic and volcanic, to which this series of mica schists gives place on the north and east, have so far proved barren of workable placers.

Farther northwest, near the mouth of Talkeetna River, a slateschist series, folded, intruded by granite, and containing abundant quartz stringers, again represents the gold-bearing series. The same rocks are also found just north of the Susitna-Cantwell divide. The bars of streams heading in this formation have for many years been worked with more or less success, and in 1898 were the scene of some local excitement. Several miles of claims were staked that year along the Chunilna, a tributary of the Talkeetna from the north. The goldbearing gravels of the newly discovered Yentna district are reported to have a slate bed rock, indicating the presence of metamorphic rocks to the west.

Though there is still question as to the relative ages of these series of rocks, there is little doubt but that their economic importance is due to the mineralization which has taken place during their infiltration by abundant quartz stringers. The concentration of gold values incident upon their wearing away by stream work has been the direct means of the formation of the placers.

The Pleistocene gravels at the head of Matanuska River are not likely to be gold bearing or of economic importance. Their glacial origin is distinctly unfavorable to the production of placer deposits. Their rapid mode of accumulation means a lack of sorting and concentration necessary for the formation of workable placers.

The present stream gravels are largely derived from reworking these older gravel sheets. Even with this partial reconcentration the gold content has not been increased sufficiently to pay for working. Productive placers appear to be limited to such streams as are directly 
engaged in concentrating a metamorphic bed rock locally bearing gold, usually in the form of small mineralized quartz stringers.

Though placers have not been found within the areas of older volcanic rocks, mineralization has occurred. West of Hicks Creek a large cropping of gossan about 100 feet wide was found. This red capping is due to the oxidation of finely divided pyrite disseminated through a quartz porphyry. A sample selected for assay showed a trace of gold and no silver.

For several miles the whole southern flank of Sheep Mountain at the head of Matanuska River is colored a strong red from the oxidation of pyrite in the greenstones. At some points the sulphuric acid formed during the oxidation of the pyrite has bleached the greenstones to a pure white color. The rugged range thus tinted in vividly contrasting colors presents a marked scenic effect. Certain streams emerging from the range are so highly charged with iron salts as to color their gravels red with oxide. The pyritization of the greenstones, which are here roughly schistose, has affected a great thickness of rocks, but is of a diffused character. An assay of a sample selected as showing the maximum mineralization yielded only a trace of gold and no silver.

\section{DESCRIPTION OF LOCALITIES.}

\section{WILLOW CREEK.}

Placer gold is being mined in commercial quantities at only one locality within the area covered during the season, i. e., on Grubstake Gulch, a southern tributary of Willow Creek, which enters Susitna River about 30 miles above its mouth. Willow Creek proper was staked by M. J. Morris and L. Herndon is 1898 , and it is reported that they extracted about $\$ 4,000$. In $1899 \mathrm{~A}$. Gilbert staked Grubstake Gulch, and in 1900 sold his interest to O. G. Herning, who manages the property for the Klondike Boston Mining Company, of Boston, Mass.

The valley of Willow Creek and the valleys of the small tributary gulches show clearly the results of ice action, the side streams occupying hanging valleys with steep gradients or falls where the smaller streams join the main water courses. Grubstake Gulch is an example of such conditions. Near its mouth a rim of bed rock crosses the channel and is cut through by the present stream, which falls preeipitously for about 150 feet in a very short distance and enters Willow Creek at a low gradient. An excellent dump for hydraulicking is thus afforded. Bed rock is a mica schist penetrated by small veinlets and augen of quartz. The schistosity at this point is N. $60^{\circ} \mathrm{E}$., with a steep dip $40^{\circ}$ to the north. The direction and inclination of the beds across the stream and the dip downstream are especially 13070-Bull. $327-07-5$ 
favorable for the collection of any gold that might be concentrated from the rocks in the process of erosion which the valley has undergone.

In the last three years, 1904-1906, during which hydraulic methods have been in use, 900 feet of the creek has been worked out. Pay averages 200 feet in width with a depth from $2 \frac{1}{2}$ to 3 feet. The gold is coarse and rough, and assays at the mint $\$ 16.58$ per ounce. Very little black sand is found. The greater part of the gold occurs close to or in crevices of the bed rock, but it is not deemed necessary to clean up by hand, the hydraulic giant being relied on to sweep all gold into the boxes.

The wash, which is practically all confined to the gulch bed, there being no well-defined bench, is coarse, ill assorted, and not greatly waterworn. The many large bowlders make it necessary to employ at least two men in breaking up and removing oversize and add materially to the cost of extraction. Three Hendy giants are installed on the property, two No. 2 and one No. 1. Only one is used at a time, however. Seven hundred inches of water with a head of 180 feet is brought three-fourths of a mile down the gulch. : A 24-inch pipe at the intake dam is reduced to 9 inches at the giant, to which is fitted a 3-inch nozzle.

The 900 feet of sluice boxes used are built entirely of whipsawed lumber. Bottom boards are $1 \frac{1}{2}$ inches thick, side boards 1 inch thick, and the frames are 3-inch square timbers. The flume is 27 feet wide and 30 feet deep by inside measurements. Block riffles are used. A grade of $5 \frac{1}{4}$ inches to $12 \frac{1}{2}$ feet is maintained. The gravel is piped downstream into the boxes. Very little gold is caught below the fourth box, the greater part being retained in the second. Mercury is placed in the third, fourth, and fifth boxes.

The origin of the gold may be ascribed with certainty to the abundant quartz stringers in the mica schists. The coarseness and roughness of the grains suggest a near source of supply. It is very probable that the discovery of placer gold in commercial quantities in this region will be in the areas where mica schist is the dominant formation or where streams have eroded rocks of that type. The fact that placer gold has not been found in paying quantities where streams have headed in granitic or other crystalline rocks bears out this statement.

Recent prospecting has developed the fact that a well-defined bench about 75 feet above the bed of Willow Creek carries gold in commercial quantities. It is planned to install during the coming winter a hydraulic plant on the south side of Willow Creek, near the mouth of Wet Gulch, 2 miless below Grubstake Gulch, for their exploitation. The excellent facilities for dumping, and a catchment area at least as large as that of Willow Creek supplying water under suffi- 
cient pressure, suggest a commercial proposition well worth investigation. The possession of the creek claims as dumping ground will be necessary. Such bench claims lend themselves particularly to exploitation by hydraulic methods and may be worked at far lower cost than gravels situated at the level of present stream drainage.

\section{NELCHINA RIVER.}

Two prospectors from Copper Center, who were met in the headwater country of the Nelchina and Tyonek rivers, reported that gold was present in all the stream gravels, but in very small quantities. The gold obtained on the Tyonek is almost exclusively in the form of small round plates, worth about a cent apiece. Occasional small shotty nuggets occur, not exceeding 5 or 10 cents in value.

It is reported that the hard conglomerate interstratified with Jurassic shales and sandstones, when panned, failed to yield colors. Yet in view of the unaltered and unmineralized character of the prevailing sandstones and shales, and in view of the comparative coarseness of the gold, it is nevertheless probable that the meager gold content of the present stream channels has been derived by a concentration of the ancient conglomerates.

KNIK RIVER.

It is reported that on Metal Creek, a tributary of Knik River, prospectors discovered pay dirt which yielded $\$ 7$ or $\$ 8$ a day to the shovel.

\section{COPPER.}

KNIK RIVER.

In August, 1906, prospectors reported the discovery of copper in the high mountains between Knik and Matanuska rivers, but this locality was not visited. The ore shown to the writer is chalcopyrite (sulphide of copper and iron), and is associated with pyrrhotite (magnetic iron pyrites). The ledge is reported to be nearly vertical and to have been traced through four claims. No actual development work has been done. The ore body is said to be 3 feet thick, consisting of 18 inches of solid chalcopyrite and 18 inches of quartz irregularly cut by stringers of ore. Graphitic gouge matter occurs near the ledge. From the foregoing description it appears probable that the deposit occupies a mineralized shear zone, similar to those found in the Prince William Sound region both in its manner of occurrence and in the bed rock with which it is associated. The mountains between Knik and Matanuska rivers, though difficult of access, are thought worthy of prospecting. 
MATANUSKA AND TALKEETNA BASINS, ALASKA.

KASHWITTNA RIVER.

The occurrence of bornite in the mountains east of the Susitna was reported as early as 1898. ${ }^{\circ}$ During the summer of 1906 assessment work was done on copper claims near the head of the north fork of Kashwitna River, a tributary of the Susitna from the Talkeetna Mountains. Samples of bornite"said to occur in a granite were seen. The claim is about 120 miles from Knik and is situated 10 miles from timber.

a Explorations in Alaska, Adjutant-General's Office, p. 167. 


\section{INDEX.}

Anthracite Ridge coal field, coal of, dese tion of ...................... 54-56

geology of ......................... 52-54

sections in ....................... 55-56

Arkose Ridge, fossils on .................... $\quad 26$

Ash in coal, percentage of................ 63

Astarte, occurrence of ...................... 18

Aucella, occurrence of ............... 21,22,30

bronni Rouiller..................... 22,23

crassicollis Keyserling................ 24

Belemnites, occurrence of............... 19,22

Billy Creek, coal on ....................... 57

fault on, view of ..................... 16

rocks on .......................... 21, 24, 29

section on, figure showing............. 57

Boulder Creek, coal near, analyses of....... 60

Cadoceras sp., occurrence of................ 22

Canoe Creek, coal on...................... 57

Cantwell River, rocks on................. 11

Caribou Creek, description of............... 8 fossils on ............................ 19

Castle Mountain, rocks cf............... 25

Chickaloon Creek, coal on, analyses of...... 60 coal on, coking of ..................... 63 sections of....................... 44-48

description of ......................... 8

fossils on.......................... 26

rocks near................ 9, 19,20,25, 29, 30

tunnels at, locations of, figure showing. . $\quad 45$

tunnels at, sections of ............... 45-48

views near.......................... 42

Chickaloon Glacier, description of ......... 33-34

Chugach Mountains, character of......... 8 8 9

Chunilna River, coal on.................... 58 gold on ..........................., 64

Coal, analyses and tests of ............... 59-63 distribution and description of . ... 5, 28, 40-59 mining of, conditions of ................ 63 metamorphism of .................. 27-28 occurrence of .................. 5, 28, 40-41

Coal Creek, coal on, analyses of ............ 60 coal on, sections of ................... 43

Coking test, results of.................... 63

Conglomerate Mountain, lake near, view of. $\quad 16$ rocks on ........................... 25 section at, figure showing............. 41 view of ............................. 42

Copper, occurrence and description of ..... 67-68 Copper River basin, description of...... 7,39-40 development of ....................... 39-40

Corylus macquarri (Forbes) Heer.
Cretaceous rocks, character and occurrence of .......................... 10, 24

Eldridge, G. H., on Susitna slate............ $11-12$ on Tyonek coals..................... 28

Eocene rocks, age of .................... 26-27 fossils of .............................. 26 occurrence and character of .......... 10, 24-28 stratigraphy of ........................ 27

Eska Creek, coal on, analyses of ............ 60 coal on, sections of ................. 49-50 view near...........................

Explorations, list of...................... 5-6

Fault block, lake in, view of ............... 16

Ficus grönlandica Heer.................... 26

Field work, outline of .....................

Geography, outline of .................... 6 6-9

Geologic history, outline of ................ 31-40

Geologic map of region ................ Pocket

Geology, description of ................... 9-40 outline of ......................... $\quad 9-10$

Gerdine, T. G., work of ..................... 6

Glaciation, description of............... 33-37 view of.............................. 16

Glaciers, recession of, view of.............. 16

Cold, distribution of .................... 64-65 occurrences of, description of ......... 65-67 origin of ............................... 66

Granite Creek, rocks on................. 19

G ravels, character and distribution of...... 30-31 gold in ......................6. 64-65, 66-67 Graywackes, occurrence and description of . 12-16 Greenstone tuffs, occurrence and description of ....................... 13-14

Greenstones, occurrence and description of.. 16-17 Grubstake Gulch, gold in ............... 65-66

Hicks Creek, coal near, analysis of......... 60 folds on .............................. 18 rocks near......................... 24,65

Historical geology, outline of ............. 31-40

Igneous rocks, intrusion of ................ 32 occurrence and character of ........ 16, 27-28

Inoceramus............................. 19 lucifer Edward, occurrence of ........ 19,53

Juglans nigella Heer................... 26, 53

Jurassic rocks, age of .................. 19, 22-23 character and distribution of.. 10,16-18, 20-22 fossils of ....................... 18-19, 22-23 plate showing ....................... 16 stratigraphie relations of .............. 23 structure of ........................ 18

Kachemak Bay, lignites on, character of... 28 
Keshwitna River, coal on................... $\quad 57$ copper on ............................. 68 rocks near.............................. 20

Kenai formation, age of .................. 26-27 coal in................................ 26 fossils of............................. 26 occurrence and character of. . 9,10,24-26,27-30 stratigraphy of ........................ 27

Kings Creek, coal on, analyses of ........... 60 coal on, sections of ..................... 48 fossils on............................... 26 glacier on ............................ 34 gravels near.......................... 31 rocks on ............................. 25

Kings Creek coal, fossils in................. 26

Knik, gravels near........................ 30-31

Knik Arm, rocks near................ 9,12,20

Knik River, copper on.................... 67 description of ........................ 8 glacier on............................. 34-36 gold on .............................. 67 rocks near........................... 12-16

Knopf, Adolph, work of.................. 6

Knowlton, F. H., fossils determined by .... 26,53

Learned, H. G., on Susitna Valley coal...... 58

Leguminosites sp.......................... $\quad 26$

Lima, occurrence of ...................... 18

Little Susitna River, glacier on............ 34

Magnolia inglefeldi Heer...................... 26

Map of region ......................... Pocket

Map, geologic, of region .................. Pocket

Martin, G. C., coal samples collected by.... $\quad 59$ fossils found by ......................... 26 on Anthracite Ridge coal............... 54-55 on Kenai fossils........................ 26 on Matanuska coal..................... 42-49 on Matanuska Valley ................... 37 on Susitna Valley coal.................. 57 sections by ....................... 43, 48, 49

Matanuska coal field, coal of, description of. 41-52 description of ......................... 40-41 extent of............................... 41 sections of ........................... 43-51 structure of.......................... 41-42

Matanuska River, coal on, analyses of..... 60,61 coal on, section of ...................... 43 description of ....................... 8, 37-38 fossils on........................... 18 glaciers on ........................... 34 gravels on ......................... 31 section at, figure showing.............. 41

Matanuska Valley, description of ........... 7-8 development of ....................... 37-38 glacier in ............................ $35-36$ gravels in........................... 31 rocks in ............................ 28,64

Mendenhall, W. C., on conglomerate of Castle Mountain. n Copper River besin................. n................ on Matanuska glaciers................... on Matanuska Valley.

Metamorphic rocks, occurrence and character of ........................ 11-16

Mica schists, occurrence and character of... 10-11 Mineral resources, description of........... 40-68 Moose Creek, view near..................... 42 Natica, occurrence of ....................... 19
Page.

Nelchina River, fossils on................ 22 gold on ............................... 67 gravels on.......................... 31

rocks along......................... 22,24

Northeastern field, coal of, description of.. 56-57 extent of............................... 56 faulting in............................ 57

structure of ............................ $56-57$

Oppelia, occurrence of .................... 19

Paige, Sidney, work of ..................... 6

Paliurus colombi Heer.................... 26

Pecten, occurrence of ..................... 18

Phylloceras, occurrence of ................ 19

Physiographic development, outline of.... 37-40

Piedmont glacier, description of ............. 35

Pleuromya, occurrence of.............. 18, 19, 22

Pleurotomaria, oscurrence of................ 19

Populus arctica Heer, occurrence of........ $\quad 26$ sp, occurrence of ....................... 26

Protocardia, occurrence of............... 18

Purinton Creek, coal at, description of..... 54 section on, figure showing .............. 56

Quartz diorite, age of ................. 20,32 occurrence and character of ............ 19-20

Quartz porphyry, occurrence and description of .........................

Quaternary deposits, character and distribution of ................ 10,30-31

Quaternary history, outline of............. 33-37

Rhamnus eridani Heer................... 26

Rhynchonella, occurrence of ............... 18

Rhyolites, occurrence and description of... 14

Salix varians Heer......................... $\quad 26$

Sargent, R. H., work of.................... 6

Schists, occurrence and character of....... 11-16

Sequoia langsdorfii (Brgt.) Heer, occurrence of ........................ 26

Sheep Creek, character of ................... 7 rocks near........................... 20

Sheep Mountain, rocks of.................. 65 Slates, occurrence and character of........ 11-12

Sonninia, occurrence of.................. 18, 19

Stanton, F. M., analyses by .............. 59,61

Stanton, T. W., fossils determined by ...... 18,22

Stephanoceras, occurrence of.............. 19

Stratigraphy, description of ............... 9-31

Sunrise "series," age of.................... 15

character of........................... 10

correlation of ....................... 15-16 occurrence and character of............ 12-15

Susitna River, description of .............. i rocks on ............................. 11,2 valley of, coal in ..................... 57-55 glacier in ......................... 36-37 Susitna slate, character and occurrence of.. 10 , .11-12,32

Talkeetna Mountains, coal in, section of.... 55 development of...................... 38-39 drainage of........................... 7 geography of ........................ $6-7$ geology of..................... 9, 17,20,29 glaciers on ............................ 33 topography of...................... 7

Talkeetna River, description of ............. 7 glacier on ................................ 35 rocks on ............................. 19,64 valley of, rocks in .................... 11-12 
Page.

Taxodium distichum miocenum Heer......

tinajorum Heer.

26

ertiary rocks, age of

26

fossils of.

26

occurrence and character of.... 10,24-28,29-30

stratigraphy of.

Trigonia, occurrence of

Tsadaka Creek, coal on, analyses of ........ 60

coal on, sections of $\ldots \ldots \ldots \ldots \ldots \ldots \ldots .51-52$

fossils on ........................ 26

rocks on ........................... 19,25

Tuffs, occurrence and description of.... 13-14,21

Tyonek, gravels at

Tyonek, lignites at, character of............ 28

Tyonek River, coal on ................... 57. gold on ................................ 67

Viburnum nordenskioldi Heer.............. 26

Viviparus, occurrence of.................... 26

Vola, occurrence of ...................... 18

Watson's camp, coal at, sections of ....... 45-48

Willow Creek, coal on .................... 57 gold on ........................... 65-67

rocks near......................... 10

Yentna gold district, rocks of ............. 64

Young Creek, coal on, analyses of.......... 60

coal on, section of.................... 49 



\section{CLASSIFICATION OF THE PUBLICATIONS OF THE UNITED STATES GEOLOGICAL SURVEY.}

[Bulletin No, 327.]

The publications of the United States Geological Survey consist of (1) Annual Reports, (2) Monographs, (3) Professional Papers, (4) Bulletins, (5) Mineral Resources, (6) Water-Supply and Irrigation Papers, (7) Topographic Atlas of United States-folios and separate sheets thereof, (8) Geologic Atlas of United Statesfolios thereof. The classes numbered 2,7 , and 8 are sold at cost of publication; the others are distributed free. A circular giving complete lists can be had on application.

Most of the above publications can be obtained or consulted in the following ways:

1. A limited number are delivered to the Director of the Survey, from whom they can be obtained, free of charge (except classes 2,7 , and 8), on application.

2. A certain number are delivered to Senators and Representatives in Congress for distribution.

3. Other copies are deposited with the Superintendent of Documents, Washington, D. C., from whom they can be had at prices slightly above cost.

4. Copies of all Government publications are furnished to the principal public libraries in the large cities throughout the United States, where they can be consulted by those interested.

The Professional Papers, Bulletins, and Water-Supply Papers treat of a variety of subjects, and the total number issued is large. They have therefore been classified into the following series: A, Economic geology; B, Descriptive geology; C, Systematic geology and paleontology; D, Petrography and mineralogy; E, Chemistry and physies; F, Geography; G, Miscellaneous; H, Forestry; I, Irrigation; J, Water storage; K, Pumping water; L, Quality of water; M, General hydrographic investigations; N, Water power; O, Underground waters; P, Hydrographic progress reports; Q, Fuels; R, Structural materials. This paper is the one hundred and fifth in Series $\mathrm{A}$ and the one hundred and twenty-ninth in Series B, the complete lists of which follow ( $\mathrm{PP}=$ Professional Paper; $\mathrm{B}=$ Bulletin; WS=Water-Supply Paper):

\section{SERIES A, ECONOMIC GEOLOGY.}

B 21. Lignites of Great Sioux Reservation: Report on region between Grand and Moreau rivers, Dakota, by Bailey Willis. 1885 . $16 \mathrm{pp} ., 5 \mathrm{pls}$. (Out of stock.)

B 46. Nature and origin of deposits of phosphate of lime, by R. A. F. Penrose, jr., with introduction by N. S. Shaler. $1888.143 \mathrm{pp}$. (Out of stock.)

B 65. Stratigraphy of the bituminous coal field of Pennsylvania, Ohio, and West Virginia, by I. C White. 1891. 212 pp., 11 pls. (Out of stock.)

B 111. Geology of Big Stone Gap coal field of Virginia and Kentucky, by M. R. Campbell. 1893. 106 pp., 6 pls. (Out of stock.)

B 132. The disseminated lead ores of southeastern Missouri, by Arthur Winslow. 1896. 31 pp. (Out of stock.)

B 138. Artesian-well prospects in Atlantic Coastal Plain region, by N. H. Darton. 1896.228 pp., 19 pls.

B 139. Geology of Castle Mountain mining district, Montana, by W. H. Weed and L. V. Pirsson. 1896. 164 pp., 17 pls.

B 143. Bibliography of clays and the ceramic arts, by J. C. Branner. $1896.114 \mathrm{pp}$

B 164. Reconnaissance on the Rio Grande coal fields of Texas, by T. W. Vaughan, including a report on igneous rocks from the San Carlos coal field, by E. C. E. Lord. 1900.100 pp., 11 pls. (Out of stock.)

B 178. El Paso tin deposits, by W. H. Weed. $1901.15 \mathrm{pp.,} 1 \mathrm{pl}$. 
B 180. Occurrence and distribution of corundum in United States, by J. H. Pratt. 1901.98 pp., 14 pls. (Out of stock; seè No. 269.)

B 182. A report on the economic geology of the Silverton quadrangle, Colorado; by F. L. Ransome. 1901. 266 pp., 16 pls. (Out of stock.)

B 184. Oil and gas fields of the western interior and northern Texas Coal Measures and of the Upper Cretaceous and Tertiary of the western Gulf coast, by G. I. Adams. 1901.64 pp., 10 pls. (Out of stock.)

B 193. The geological rélations and distribution of platinum and associated metals, by J. F. Kemp. 1902. 95 pp., 6 pls.

B 198. The Berea grit oil sand in the Cadiz quadrangle, Ohio, by W. T. Griswold. $1902.43 \mathrm{pp} ., 1 \mathrm{pl}$. (Out of stock.)

PP 1. Preliminary report on the Ketchikan mining district, Alaska, with an introductory sketch of the geology of southeastern Alaska, by A. H. Brooks. 1902.120 pp., 2 pls.

B. 200. Reconnaissance of the borax deposits of Death Valley and Mohave Desert, by M. R. Camplell. 1902. $23 \mathrm{pp} ., 1 \mathrm{pl}$. (Out of stock.)

B 202. Tests for gold and silver in shales from western Kansas, by Waldemar Lindgren. 1902. $21 \mathrm{pp.}$ (Out of stock.)

PP 2. Reconnaissance of the northwestern portion of Seward Peninsula, Alaska, by A. J. Collier. 1902. 70 pp., 11 pls.

PP 10. Reconnaissance from Fort Hamlin to Kotzebue Sound, Alaska, by way of Dall, Kanuti, Allen, and Kowak rivers, by W. C. Mendenhall. 1902.68 pp., 10 pls.

PP 11. Clays of the United States east of the Mississippi River, by Heinrich Ries. 1903.298 pp., 9 pls. (Out of stock.)

PP 12. Geology of the Globe copper district, Arizona, by F. L. Ransome. 1903.168 pp., 27 pls.

B 212. Oil fields of the Texas-Louisiana Gulf Coastal Plain, by C. W. Hayes and William Kennedy. 1903. 174 pp., 11 pls. (Out of stock.)

B 213. Contributions to economic geology, 1902; S. F. Emmons and C. W. Hayes, geologists in charge. 1903. $449 \mathrm{pp}$. (Out of stock.)

PP 15. The mineral resources of the Mount Wrangell district, Alaska, by W. C. Mendenhall and F. C. Schrader. $1903.71 \mathrm{pp} ., 10 \mathrm{pls}$.

B 218. Coal resources of the Yukon, Alaska, by A. J. Collier. 1903.71 pp., 6 pls.

B 219. The ore deposits of Tonopah, Nevada (preliminary report), by J. E. Spurr. 1903.31 pp., 1 pl. (Out of stock.)

PP 20. A reconnaissance in northern Alaska in 1901, by F. C. Schrader. 1904.139 pp., 16 pls.

PP 21. Geology and ore deposits of the Bisbee quadrangle, Arizona, by F. L. Ransome. 1904. 168 pp., 29 pls.

B 223. Gypsum deposits in the United States, by G. I. Adams and others. 1904.129 pp., 21 pls. (Out of stock.)

PP 24. Zinc and lead deposits of northern Arkansas, by G. I. Adams. 1904.118 pp., 27 pls.

PP 25. Copper deposits of the Encampment district, Wyoming, by A. C. Spencer. 1904.107 pp., 2 pls. (Out of stock.)

B 225. Contributions to economic geology, 1903, by S. F. Emmons and C. W. Hayes, geologists in charge. 1904. $527 \mathrm{pp} ., 1 \mathrm{pl}$. (Out of stock.)

PP 26. Economic resources of the northern Black Hills, by J. D. Irving, with contributions by \&. F. Emmons and T. A. Jaggar, jr. 1904.222 pp., 20 pls.

PP 27. A geological reconnaissance across the Bitterroot Range and Clearwater Mountains in Montana and Idaho, by Waldemar Lindgren. 1904.123 pp., 15 pls.

B 229. Tin deposits of the York region, Alaska, by A. J. Collier. 1904.61 pp., 7 pls.

B 236. The Porcupine placer district, Alaska, by C. W. Wright. 1904.35 pp., 10 pls.

B 238. Economic geology of the Iola quadrangle, Kansas, by G. I. Adams, Erasmus Haworth, and W. R. Crane. 1904.83 pp., 11 pls.

B 243. Cement materials and industry of the United States, by E. C. Eckel. $1905.395 \mathrm{pp} ., 15 \mathrm{pls}$.

B 246. Zinc and lead deposits of northwestern Illinois, by H. Foster Bain. 1904.56 pp., 5 pls.

B 247. The Fairhaven gold placers of Seward Peninsula, Alaska, by F. H. Moffit. 1905.85 pp., 14 pls.

B 249. Limestones of southeastern Pennsylvania, by F. G. Clapp. 1905.52 pp., 7 pls.

B 250. The petroleum fields of the Pacific coast of Alaska, with an account of the Bering River coal deposits, by G. C. Martin. 1905.65 pp., 7 pls.

B 251. The gold placers of the Fortymile, Birch Cree'z, and Fairbanks regions, Alaska, by L. M. Prindle. 1905. 89 pp., 16 pls.

WS 117. The lignite of North Dakota and its relation to irrigation, by F. A. Wilder. 1905.59 pp., s pls.

PP 36. The lead, zinc, and fluorspar deposits of western Kentucky, by E. O. Ulrich and W. S. T. Smith. 1905. 218 pp., 15 pls.

PP 38. Economic geology of the Bingham mining district, Utah, by J. M. Boutwell, with a chapter on areal geology, by Arthur Keith, and an introduction on general geology, by S. F. Emmons. 1905. 413 pp., 49 pls.

PP 41. Geology of the central Copper River region, Alaska, by W. C. Mendenhall. 1905.133 pp., 20 pls.

B 254. Report of progress in the geological resurvey of the Cripple Creek district, Colorado, by Waldemar Lindgren and F. L. Ransome. 1904. 36 pp. 
B 255. The fluorspar deposits of southern Illinois, by H. Foster Bain. 1905.75 pp., 6 pls. (Out of stock.)

B 256. Mineral resources of the Elders Ridge quadrangle, Pennsylvania, by R. W. Stone. 1905. 86 pp., 12 pls.

B 259. Report on progress of investigations of mineral resources of Alaska in 1904, by A. H. Brooks and others. $1905.196 \mathrm{pp} ., 3 \mathrm{pls}$.

B 260. Contributions to economic geology, 1904; S. F. Emmons and C. W. Hayes, geologists in charge. 1905. 620 pp., 4 pls.

B 261. Preliminary report on the operations of the coal-testing plant of the United States Geological Survey at the Louisiana Purehase Exposition, St. Louis, Mo., 1904; E. W. Parker, J. A. Holmes, and M. R. Campbell, committee in charge. 1905. $172 \mathrm{pp.} \mathrm{(Out} \mathrm{of} \mathrm{stock.)}$

B 263. Methods and cost of gravel and placer mining in Alaska, by C. W. Purington. $1905.273 \mathrm{pp}$., 42 pls. (Out of stock.)

PP 42. Geology of the Tonopah mining district, Nevada, by J. E. Spurr. 1905.295 pp., 24 pls.

PP 43. The copper deposits of the Clifton-Morenei distriet, Arizona, by Waldemar Lindgren. 1905. 375 pp., $25 \mathrm{pls}$.

B 264. Record of deep-well drilling for 1904, by M. L. Fuller, E. F. Lines, and A. C. Veatch. 1905. $106 \mathrm{pp}$.

B 265. Geology of the Boulder district, Colorado, by N. M. Fenneman. $1905.101 \mathrm{pp}, 5$ pls.

B 267. The copper deposits of Missouri, by H. Foster Bain and E. O. Ulrich. $1905.52 \mathrm{pp} ., 1 \mathrm{pl}$.

B 269. Corundum and its occurrence and distribution in the United States (a revised and enlarged edition of Bulletin No. 180), by J. H. Pratt. 1906.175 pp., 18 pls.

PP 48. Report on the operations of the coal-testing plant of the United States Geological Survey at the Louisiana Purchase Exposition, St. Louis, Mo., 1904; E. W. Parker, J. A. Holmes, M. R. Campbell, committee in charge. 1906. (In three parts.) $1,492 \mathrm{pp} ., 13 \mathrm{pls}$.

B 275. Slate deposits and slate industry of the United States, by T. N. Dale, with sections by E. C. Eckel, W. F. Hillebrand, and A. T. Coons. 1906.154 pp., 25 pls.

PP 49. Geology and mineral resources of part of the Cumberland Gap coal field, Kentueky, by G. H. Ashley and L. C. Glenn, in cooperation with the State Geological Department of Kentucky, C. J. Norwood, curator. 1906.239 pp., 40 pls.

B 277. Mineral resources of Kenai Peninsula, Alaska: Gold fields of the Turnagain Arm region, by F. H. Moffit; Coal fields of the Kachemak Bay region, by R. W. Stone. 1906.80 pp., 18 pls.

B 278. Geology and coal resources of the Cape Lisburne region, Alaska, by A.J. Collier. 1906. 54 pp., 9 pls. (Out of stock.)

B 279. Mineral resources of the Kittanning and Rural Valley quadrangles, Pennsylvania, by Charles Butts. 1906. $198 \mathrm{pp} ., 11 \mathrm{pls}$.

B 280. The Rampart gold placer region, Alaska, by L. M. Prindle and F. L. Hess. 1906.54 pp., 7 pls. (Out of stock.)

B 282. Oil fields of the Texas-Louisiana Gulf Coastal Plain, by N. M. Fenneman. 1906.146 pp., 11 pls.

PP 51. Geology of the Bighorn Mountains, by N. H. Darton. 1906.129 pp., 47 pls.

B 283. Geology and mineral resources of Mississippi, by A. F. Crider. 1906 . 99 pp., 4 pls.

B 284. Report on progress of investigations of the mineral resources of Alaska in 1905, by A. H. Brooks and others. $1906.169 \mathrm{pp} ., 14 \mathrm{pls}$.

B 285. Contributions to economic geology, 1905; S. F. Emmons and E. C. Eckel, geologists in charge. 1906. $506 \mathrm{pp} ., 13 \mathrm{pls}$. (Out of stock.)

B 286. Economic geology of the Beaver quadrangle, Pennsylvania, by L. H. Woolsey. 1906.132 pp., 8 pls.

B 287. Juneau gold belt, Alaska, by A. C. Spencer, and A reconnaissance of Admiralty Island, Alaska, by C. W. Wright. 1906.161 pp., 27 pls.

PP 54. The geology and gold deposits of the Cripple Creek district, Colorado, by W. Lindgren and F. L. Ransome. 1906.516 pp., 29 pls. .

PP 55. Ore deposits of the Silver Peak quadrangle, Nevada, by J. E. Spurr. 1906. 174 pp., 24 pls.

B 289. A reconnaissance of the Matanuska coal field, Alaska, in 1905, by G. C. Martin. 1906. 34 pp., 5 pls.

B 290. Preliminary report on the cperations of the fuel-testing plant of the United States Geological Survey at St. Louis, Mo., 1905, by J. A. Holmes. 1906. $240 \mathrm{pp}$.

B 293. Reconnaissance of some gold and tin deposits of the southern Appalachians, by L. C. Graton, with notes on the Dahlonega mines, by W. Lindgren. 1906.134 pp., 9 pls.

B 294. Zinc and lead deposits of the upper Mississippi Valley, by H. Foster Bain. 1906. 155 pp., 16 pls. B 295. The Yukon-Tanana region, Alaska, description of Circle quadrangle, by L. M. Prindle. 1906. 27 pp., 1 pl.

B 296. Economic geology of the Independence quadrangle, Kansas, by Frank C. Schrader and Erasmus Haworth. 1906.74 pp., 6 pls.

B 297. The Yampa coal field, Routt County, Colo., by N. M. Fenneman, Hoyt S. Gale, and M. R. Campbell. 1906. 96 pp., 9 pls.

B 29s. Record of deep-well drilling for 1905, by Myron L. Fuller and Samuel Sanford. 1906. $299 \mathrm{pp.}$

B 300. Economic geology of the Amity quadrangle in eastern Washington County, Pa., by Frederick G. Clapp. 1907. 145 pp., 8 pls. 
B 308. Preliminary account of Goløfield, Bullfrog; and other mining districts in southern Nevada, by F. L. Ransome; with notes on the Mankattan district, by G. H. Garrey and W. H. Emmons. 1906. 98 pp., 5 pls.

B 304. Oil and gas fields of Greene County, Pa., by.Ralph W.Stone and Frederick G.Clapp. 1906. 110 pp., 3 pls.

PP 56. Geography and geology of a portion of southwestern Wyoming, with special reference to coal and oil, by A. C. Veatch. 1907.178 pp., 26'pls.

B 308. A geologic reconnaisance in southwestern Nevada and eastern California, by S. H. Ball. 1907. 218 pp., 3 pls.

B 309. The Santa Clara Valley, Puente Hills, and Los Angeles oil districts, southern California, by G. H. Eldridge and Ralph Arnold. 1907. 266 pp., 41 pls.

B 312. The interaction between minerals and water solutions, with special reference to geologic phenomena, by E. C. Sullivan. 1907. $69 \mathrm{pp}$.

B 313. The granites of Maine, by T. Nelson Dale, with an introduction by G. O. Smith. 1907. 202 pp., 14 pls.

B 314. Report of progress of investigations of mineral resources of Alaska in 1906, by A. H. Brooks and others. 1907. 235 pp., 4 pls.

B 815. Contributions to economic geology, 1906, Part I: Metals and nonmetals, except fuels; S. F. Emmons and E. C. Eckel, geologists in charge. 1907. 504 pp., 4 pls.

Ws 215. Geology and water resources of a portion of the Missouri River Valley in northeastern Nebraska, by G. E. Condra. 1908. - pp., 11 pls.

Ws 216. Geology and water resources of the Republican River Valley in Nebraska and adjacent areas, by G. E. Condra. 1907 . 71 pp., 13 pls.

B 316. Contributions to economic geology, 1906; Part-II: Coal, lignite, and peat. M. R. Campbell, geologist in charge. 1907.543 pp., 23 pls.

B 817. Preliminary report on the Santa Maria oil district, Santa Barbara County, Cal., by Ralph Arnold and Robert Anderson. 1907. 69 pp., 2 pls.

B 318. Geology of oil and gas fields in Steubenville, Burgettstown, and Claysville quadrangles, Ohio, West Virginia, and Pennsylvania, by W. T. Griswold and M. J. Munn. 1907. 196 pp., 13 pls.

B 320. The Downtown district of Leadville, Colo., by S. F. Emmons and J. D. Irving. 1907.75 pp., 7 pls.

B 321. Geology and oil resources of the Summerland district, Santa Barbara County, Cal., by Ralph Arnold. 1907. 91 pp., 20.pls.

B 322. Geology and oil resources of the Santa Maria oil district, Santa Barbara County, Cal., by Ralph Arnold and Robert Anderson. 1907. 161 pp., 26 pls.

B. 326. The Arkansas coal field, by A. J. Collier, with reports on the paleontology, by David White and G. H. Girty. 1907. - pp., 6 pls.

B. 327. Geologic reconnaissance in Matanuska and Talkeetna basins, by Sidney, Paige and Adolph Knopf. 1907.71 pp., 4 pls.

\section{SERIES B, DESCRIPTIVE GEOLOGY.}

B 23. Observations on the junction between the Eastern sandstone and the Keweenaw series on Keweenaw Point, Lake Superior, by R. D. Irving and T. C. Chamberlin. 1885. 124 pp., 17 pls. (Out of stock.)

B 33. Notes on geology of northern California, by J. S. Diller. 1886. 23 pp. (Out of stock.)

B 39. The upper beaches and deltas of Glacial Lake Agassiz, by Warren Upham. $1887.84 \mathrm{pp} ., 1 \mathrm{pl}$. (Out of stock.)

B 40. Changes in river courses in Washington Territory due to glaciation, by Bailey Willis. 1887. 10 pp., 4 pls. (Out of stock.)

B 45. The present condition of knowledge of the geology of Texas, by R. T. Hill. 1887.94 pp. (Out of stock.)

B 53. The geology of Nantucket, by N. S. Shaler. 1889.55 pp., 10 pls. (Out of stock.)

B 57. A geological reconnaissance in southwestern Kansas, by Robert Hay. 1890.49 pp., 2 pls.

B 58. The glacial boundary in western Pennsylvania, Ohio, Kentucky, Indiana, and Illinois, by G. F. Wright, with introduction by T. C. Chamberlin. 1890. $112 \mathrm{pp} ., 8 \mathrm{pls}$. (Out of stock.)

B 67. The relations of the traps of the Newark system in the New Jersey region; by N. H. Darton. 1890. 82 pp. (Out of stock.)

B 104. Glaciation of the Yellowstone Valley north of the Park, by W. H. Weed. 1893.41 pp., 4 pls.

B 108. A geological reconnaissance in central Washingtọn, by I. C. Russell. 1898. 108 pp., 12 pls. (Out of stock.)

B 119. Á geological reconnaissance in northwest Wyoming, by G. H. Eldridge. 1894.72 pp., 4 pls.

B 187. The geology of the Fort Riley Military Reservation and vicinity, Kansas, by Robert Hay. 1896. 35 pp., 8 pls.

B 144. The moraines of the Missouri Coteau and their attendant deposits, by J. E. Todd. 1896. 71 pp., 21 pls.

B 158. The moraines of southeastern South Dakota and their attendant deposits, by J. E. Todd. 1899. $171 \mathrm{pp} ., 27$ pls.

B 159. The geology of eastern Berkshire County, Massachusetts, by B. K. Emerson. 1899. 139 pp., 9 pls. 
B 165. Contributions to the geology of Maine, by H. S. Williams and H. E. Gregory. 1900. 212 pp., 14 pls.

WS 70. Geology and water resources of the Patrick and Goshen Hole quadrangles in eastern Wyoming and western Nebraska, by G. I. Adams. 1902.50 pp., 11 pls.

B 199. Geology and water resources of the Snake River Plains of Idaho, by I. C. Russell. 1902.192 pp., 25 pls.

PP 1. Preliminary report on the Ketchikan mining district, Alaska, with an introductory sketch of the geology of southeastern Alaska, by A. H. Brooks. 1902. 120 pp., 2 pls.

PP 2. Reconnaissance of the northwestern portion of Seward Peninsula, Alaska, by A. J. Collier. 1902. 70 pp., 11 pls.

PP 3. Geology and petrography of Crater Lake National Park, by J. S. Diller and H. B. Patton. 1902. 167 pp., 19 pls.

PP 10. Reconnaissance from Fort Hamlin to Kotzebue Sound, Alaska, by way of Dall, Kanuti, Allen, and Kowak rivers, by W. C. Mendenhall. 1902. 68 pp., 10 pls.

PP 11. Clays of the United States east of the Mississippi River, by Heinrich Ries. 1903. 298 pp., 9 pls. (Out of stock.)

PP 12. Geology of the Globe copper district, Arizona, by F. L. Ransome. 1903. 168 pp., 27 pls.

PP 13. Drainage modifications in southeastern Ohio and adjacent parts of West Virginia and Kentucky, by W. G. Tight. $1903.111 \mathrm{pp} ., 17 \mathrm{pls.} \mathrm{(Out} \mathrm{of} \mathrm{stock.)}$

B 208. Descriptive geology of Nevada south of the fortieth parallel and adjacent portions of California, by J. E. Spurr. 1903.229 pp., 8 pls. (Out of stock.)

B 209. Geology of Ascutney Mountain, Vermont, by R. A. Daly. 1903.122 pp., 7 pls.

WS 78. Preliminary report on artesian basins in southwestern Idaho and southeastern Oregon, by I. C. Russell. 1903. 51 pp., 2 pls.

PP 15. Mineral resources of the Mount Wrangell district, Alaska, by W. C. Mendenhall and F. C. Schrader. 1903. 71 pp., 10 pls.

PP 17. Preliminary report on the geology and water resources of Nebraska west of the one hundred and third meridian, by N. H. Darton. $1903.69 \mathrm{pp} ., 43 \mathrm{pls}$.

B 217. Notes on the geology of southwestern Idaho and southeastern Oregon, by I. C. Russell. 1903. 83 pp., 18 pls.

B 219. The ore deposits of Tonopah, Nevada (preliminary report), by J. E. Spurr. $\quad 1903 . \quad 31$ pp., 1 pl.

PP 20. A reconnaissance in northern Alaska in 1901, by F. C. Schrader. 1904.139 pp., 16 pls.

PP 21. The geology and ore deposits of the Bisbee quadrangle, Arizona, by F. L. Ransome. 1904.168 pp., 29 pls.

WS 90. Geology and water resources of part of the lower James River Valley, South Dakota, by J.E. Todd and C. M. Fall. 1904.47 pp., 23 pls.

PP 25. The copper deposits of the Encampment district, Wyoming, by A. C. Spencer. 1904.107 pp., 2 pls. (Out of stock.)

PP 26. Economic resources of the northern Black Hills, by J. D. Irving, with contributions by S. F. Emmons and T. A. Jaggar, jr. 1904. 222 pp., 20 pls.

PP 27. A geological reconnaissance across the Bitterroot Range and Clearwater Mountains in Montana and Idaho, by Waldemar Lindgren. $1904.122 \mathrm{pp}, 15 \mathrm{pls}$.

PP 31. Preliminary report on the geology of the Arbuckle and Wichita mountains in Indian Territory and Oklahoma, by J. A. Taff, with an appendix on reported ore deposits in the Wichita Mountains, by H. F. Bain. 1904.97 pp., 8 pls.

B 235. A geological reconnaissance across the Cascade Range near the forty-ninth parallel, by G. $U$. Smith and F. C. Calkins. 1904. 103 pp., 4 pls.

B 236. The Poreupine placer district, Aiaska, by C. W. Wright. $1904.35 \mathrm{pp} ., 10 \mathrm{pls}$.

B 237. Igneous rocks of the Highwood Mountains, Montana, by L. V. Pirsson. 1904. 208 pp., 7 pls.

B 238. Economic geology of the Iola quadrangle, Kansas, by G. I. Adams, Erasmus Haworth, and W. R. Crane. 1904.83 pp., 1 pl.

PP 32. Geology and underground water resources of the central Great Plains, by N. H. Darton. 1905. 433 pp., $72 \mathrm{pls}$.

WS 110. Contributions to hyđrology of eastern United States, 1904; M. L. Fuller, geologist in charge, 1905. 211 pp., 5 pls.

B 242. Geology of the Hudson Valley between the Hoosic and the Kinderhook, by T. Nelson Dale, 1904. 63 pp., 3 pls.

PP 34. The Delavan lobe of the Lake Michigan glacier of the Wisconsin stage of glaciation and associated phenomena, by W. C. Alden. 1904. 106 pp., 15 pls.

PP 35. Geology of the Perry Basin in southeastern Maine, by G. O. Smith und David White. 1905. 107 pp., 6 pls.

B 243. Cement materials and industry of the United States, by E. C. Eckel. $1905.395 \mathrm{pp} ., 15 \mathrm{pls}$.

B 246. Zinc and lead deposits of northeastern Illinois, by H. F. Bain. 1904.56 pp., 5 pls.

B 247. The Fairhaven gold placers of Seward Peninsula, Alaska, by F. H. Moffit. 1905.85 pp., 14 pls.

B 249. Limestones of southwestern Pennsylvania, by F. G. Clapp. 1905. 52.pp., 7 pls.

B 250. The petroleum fields of the Pacific coast of Alaska, with an account of the Bering River coal deposit, by G. C. Martin. 1905.65 pp., 7 pls.

B 251. The gold placers of the Fortymile, Birch Creek, and Fairbanks regions, Alaska, by L. M. Prindle. 1905. 16 pp., 16 pls. 
W8 118. Geology and water resources of a portion of east-central Washington, by F. C. Calkins. 1905. 96 pp., 4 pls.

B 252. Preliminary report on the geology and water resources of central Oregon, by I. C. Russell. 1905. 138 pp., 24 pls.

PP 36. The lead, zinc, and fluorspar deposits of western Kentucky, by E. O. Ulrich and W. S. Tangier Smith. 1905. 218 pp., 15 pls.

PP 38. Economic geology of the Bingham mining district of Utah, by J. M. Boutwell, with a chapter on areal geology, by Arthur Keith, and an introduction on general geology, by S. F. Emmons. 1905. 413 pp., 49 pls.

PP 41. The geology of the central Copper River region, Alaska, by W. C. Mendenhall. 1905.133 pp., 20 pls.

B 254. Report of progress in the geological resurvey of the Cripple Creek district, Colorado, by Waldemar Lindgren and F. L. Ransome. 1904. 36 pp.

B 255. The fluorspar deposits of southern mlinois, by H. Foster Bain. $1905.75 \mathrm{pp} ., 6$ pls. (Out of stock.)

B 256. Mineral resources of the Elders Ridge quadrangle, Pennsylvania, by R. W. Stone. 1905. 85 pp., 12 pls.

B 257. Geology and paleontology of the Judith River beds, by T. W. Stanton and J. B. Hatcher, with a chapter on the fossil plants, by F. H. Knowlton. 1905.174 pp., 19 pls.

PP 42. Geology. of the Tonopah mining district, Nevada, by J. E. Spurr. 1905. 295 pp., 24 pls.

WS 123. Geology and underground water conditions of the Jornada del Muerto, New Mexico, by C. R. Keyes. 1905. 42 pp., 9 pls. (Out of stock.)

WS 136. Underground waters of Salt River Valley, Arizona, by W. T. Lee. 1905.194 pp., 24 pls.

PP 43. The copper deposits of Clifton-Morenci, Arizona, by Waldemar Lindgren. 1905. 375 pp., 25 pls.

B 265. Geology of the Boulder district, Colorado, by N. M. Fenneman. 1905.101 pp., 5 pls.

B 267. The copper deposits of Missouri, by H. F. Bain and E. O. Ulrich. $1905.52 \mathrm{pp} ., 1 \mathrm{pl}$.

PP 44. Underground water resources of Long Island, New York, by A. C. Veatch and others. 1905. 394 pp., 34 pls.

WS 148. Geology and water resources of Oklahoma, by C. N. Gould. 1905.178 pp., 22 pls.

B 270. The configuration of the rock floor of Greater New York, by W. H. Hobbs. 1905.96 pp., 5 pls.

B 272. Taconic physiography, by T. M. Dale. 1905.52 pp., 14 pls.

PP 45. The geography and geology of Alaska, a summary of existing knowledge, by A. H. Brooks, with a section on climate, by Cleveland $A b b e, j r .$, and a topographic map and description thereof, by R. M. Goode. 1905 . 327 pp., 34 pls.

B 273. The drumlins of southeastern Wisconsin (preliminary paper), by W. C. Alden. 1905. 46 pp., 9 pls.

PP 46. Geology and underground water resources of northern Louisiana and southern Arkansas, by A. C. Veatch. $1906.422 \mathrm{pp} ., 51 \mathrm{pls}$.

PP 49. Geology and mineral resources of part of the Cumberland Gap coal field, Kentucky, by G. H. Ashley and L. C. Glenn, in cooperation with the State Geological Department of Kentucky. C. J. Norwood, curator. 1906.239 pp., 40 pls.

PP 50. The Montana lobe of the Keewatin ice sheet, by F. H. H. Calhoun. 1906.62 pp., 7 pls.

B 277. Mineral resources of Kenai peninsula, Alaska: Gold fields of the Turnagain Arm region, by F. H. Moffit; and the coal fields of the Kachemak Bay region, by R. W. Stone. $1906.80 \mathrm{pp}$., 18 pls.

WS 154. The geology and water resources of the eastern portion of the Panhandle of Texas, by C. N. Gould. 1906.64 pp., 15 pls.

B 278. Geology and coal resources of the Cape Lisburne region, Alaska, by A. J. Collier. 1906. 54 pp., 9 pls. (Out of stock.)

B 279. Mineral resources of the Kittanning and Rural Valley quadrangles, Pennsylvania, by Charles Butts. 1906. 198 pp., 11 pls.

B 280. The Rampart gold placer region, Alaska, by. L. M. Prindle and F. L. Hess. 1906. 54 pp., 7 pls. (Out of stock.)

B 282. Oil fields of the Texas-Louisiana Gulf Coastal Plain, by N. M. Fenneman. 1906.146 pp., 11 pls.

WS 157 . Underground water in the valleys of Utah Lake and Jordan River, Utah, by G. B. Richardson. 1906. 81 pp., 9 pls.

PP 51. Geology of the Bighorn Mountains, by N. H. Darton. 1906.129 pp., 47 pls.

WS 158. Preliminary report on the geology and underground waters of the Roswell artesian area, New Mexico, by C. A. Fisher. 1906. 29 pp., 9 pls.

PP 52. Geology and underground waters of the Arkansas Valley in eastern Colorado, by N. H. Darton. 1906. 90 pp., 28 pls.

WS 159. Summary of underground-water resources of Mississippi, by A. F. Crider and L. C. Johnson. 1906. 86 pp., 6 pls.

PP 53. Geology and water resources of the Bighorn basin, Wyoming, by C. A..Fisher. 1906. 72 pp. 16 pls.

B 283. Geology and mineral resources of Mississippi, by A. F. Crider. 1906. 99 pp., 4 pls.

B 286. Economic geology of the Beaver quadrangle, Pennsylvania (southern Beaver and northwestern Allegheny counties), by L. H. Woolsey. 1906.132 pp., 8 pls.

B 287. The Juneau gold belt, Alaska, by-A. C. Spencer, and a reconnaissance of Admiralty Island, Alaska, by C. W. Wright. 1906. 161 pp., 37 pls. 
PP 54. The geology and gold deposits of the Cripple Creek district, Coloraito, by W. Lindgren and F. L. Ransome. 1906.516 pp., 29 pls.

PP 55. Ore deposits of the Silver Peak quadrangle, Nevada, by J. E. Spurr. 1906.174 pp., 24 pls.

B 289. A reconnaissance of the Matanuska coal field, Alaska, in 1905, by G. C. Martin. 1906.36 pp., 5 pls.

WS 164. Underground waters of Tennessee and Kentucky west of Tennessee River and of an adjacent area in Illinois, by L. C. Glenn. $1906.173 \mathrm{pp} ., 7 \mathrm{pls}$.

B 293. Reconnaissance of some gold and tin deposits of the southern Appalachians, by L. C. Groton, with notes on the Dahlonega mines, by W. Lindgren. $1906.134 \mathrm{pp} ., 9 \mathrm{pls}$.

B 294. Zine and lead deposits of the upper Mississippi Valley, by H. Foster Bain. 1906. 155 pp., 16 pls.

B 295. The Yukon-Tanana region, Alaska, description of Circle quadrangle, by L. M. Prindle. 1906. $27 \mathrm{pp} ., 1 \mathrm{pl}$.

B 296. Economic geology of the Independence quadrangle, Kansas, by Frank C. Schrader and Erasmus Haworth. 1906. $74 \mathrm{pp} ., 6 \mathrm{pls}$.

WS 181. Geology and water resources of Owens Valley, California, by Willis T. Lee. 1906. 28 pp., 6 pls.

B 297. The Yampa coal field, Routt County, Colo., by N. M. Fenneman, Hoyt S. Gale, and M. R. Campbell. 1906. 93 pp., 9 pls.

B 300. Economic geology of the Amity quadrangle in eastern Washington County, Pa., by F. G. Clapp. $1906.145 \mathrm{pp} ., 8 \mathrm{pls}$.

B 303. Preliminary account of Goldfield, Bullfrog, and other mining districts in southern Nevada, by F. L. Ransome; with notes on Manhattan distriet, by G. H. Garrey and W. H. Emmons. 1907. 98 pp., 5 pls.

B 304. Oil and gas fields of Greene County, Pa., by R. W. Stone and F. G. Clapp. 1907.110 pp.,3 pls.

WS 188. Water resources of the Rio Grande Valley in New Mexico and their development, by W. T. Lee. 1906.59 pp., 10 pls.

B 306. Rate of recession of Niagara Falls, accompanied by a report on the survey of the crest, by W. Carvel Hall. 1906. 31 pp., 11 pls.

PP 56. Geography and geology of a portion of southwestern Wyoming, with special reference to coal and oil, by A. C. Veatch. $1907.178 \mathrm{pp} ., 26 \mathrm{pls}$.

B 308. A geologic reconnaissance in sonthwestern Nevada and eastern California, by S. H. Ball. 1907. 218 pp., 3 pls.

B 309. The Santa Clara Valley, Puente Hills, and Los Angeles oil districts, southern California, by G. H. Eldridge and Ralph Arnold. 1907. $266 \mathrm{pp} ., 41 \mathrm{pls}$.

PP 57. Geology of the Marysville mining district, Montana, a study of igneous intrusion and contact metamorphism, by Joseph Barrell. 1907. 178 pp., 16 pls.

WS 191. The geology and water resources of the western portion of the Panhandle of Texas, by C. $\mathrm{N}$. Gould. 1907. 70 pp., 7 pls.

B 311. The green schists and associated granites and porphyries of Rhode Island, by B. K. Emerson and J. H. Perry. 1907. 74 pp., 2 pls.

WS 195. Underground waters of Missouri, their geology and utilization, by Edward Shepard. 1907. 224 pp., 6 pls.

WS 199. Underground water in Sanpete and central Sevier valleys, Utah, by G. B. Richardson. 1907. 63 pp., 6 pls.

WS 215. Geology and water resources of a portion of the Missonri River Valley in northeastern Nebraska, by G. E. Condra. 1908. - pp., 11 pls.

WS 216. Geology and water resources of the Republican River Valley in Nebraska and adjacent areas, by G. E. Condra. 1907. 71 pp., 13 pls.

B 317. Preliminary report on the Santa Maria Oil district, Santa Barbara County, Cal, by Ralph Arnold and Robert Anderson. 1907. 69 pp., 2 pls.

B 318. Geology of oil and gas fields in Steubenville, Burgettstown, and Claysville quadrangles, Ohio, West Virginia, and Pennsylvania, by W. T. Griswold and M. J. Mumn. 1907. 196 pp., 13 pls.

B 319. Summary of controlling factors of artesian flows, by M. L. Fuller. 1908. - pp., 7 pls.

B 320. The Downtown distriet of Leadville, Colo., by S. F. Emmons and J. D. Irving. 1907. 75 pp., 7 pls.

B 321. Geology and oil resources of the Summeriand district, Santa Barbara County, Cal., by Ralph Arnold. 1907. 91 pp., 20 pls.

B 322. Geology and oil resources of the Santa Maria oil district, Santa Barbara County, Cal., by Ralph Arnold and Robert Anderson. 1907. 161 pp., 26 pls.

B 326. The Arkansas conl field, by A. J. Collier, with reports on the paleontology, by David white and G. H. Girty. 1907. - pp., 6 pls.

B 327. Geologic reconnaissance in the Matanuska and Talkeetna basins, by Sidney Paige and Adolph Knopf. 1907. 71 pp., 4 pls.

Correspondence should be addressed to

THE IIRECTOR,

United States Geological Survey,

December, 1907.

WASHINGTON, D. C. 


\section{GEOLOGICAL SURVEY PUBLICATIONS ON ALASKA.}

1891 .

Russelu, I. C. Account of an expedition to the Yukon Valley in 1889. In Eleventh Ann. Rept., pt. 1, 1891, pp. 57-58. Extract from Professor Russell's complete report in Bull. Geol. Soc. America, vol. 1, 1890, pp. 99-162. (Out of stock.)

Account of an expedition to the vicinity of Mount St. Elias in 1890. In Twelfth Ann. Rept., pt. 1, 1891, pp. 59-61. A full report of this expedition was published in Nat. Geog. Mag., vol. 3, 1892, pp. 53-203. (Out of stock.)

1892.

DALL, W. H., and HARRIs, G. D. Summary of knowledge of Neocene geology of Alaska. In correlation Papers-Neocene: Bull. No. 84, 1892, pp. 232-268.

HAYEs, C. W. Account of expedition through the Yukon district. In Thirteenth Ann. Rept., pt. 1, 1892, pp. 91-94. A complete report was published in Nat. Geog. Mag., vol, 4, 1892, pp. 117-162. (Out of stock.)

1893.

Russert, I. C. Second expedition to Mount St. Elias in 1891. In Thirteenth Ann. Rept., pt. 2, 1893, pp. 1-91. (Out of stock.)

1896.

DALL, W. H. Report on coal and lignite of Alaska. In Seventeenth Ann. Rept., pt. 1, 1896, pp. 763-906. (Out of stock.)

-Rein, H. F. Glacier Bay and its gläciers. In Sixteenth Ann. Rept., pt. 1, 1896, pp. 415-461. (Out of stock.)

W ALCOTT, C. D., Director. Account of an investigation of the gold and coal deposits of southern Alaska. In Seventeenth Ann. Rept., pt. 1, 1896, pp. 56-59. (Out of stock.)

1897.

WALCoTT, C. D., Director. Account of a reconnaissance of the gold district of the Yukon region. In Eighteenth Ann. Rept., pt. 1, 1897, pp. 52-54.

1898.

BECKER, G. F. Reconnaissance of the gold fields of southern Alaska, with some notes on general geology. In Eighteenth Ann. Rept., pt. 3; 1898, pp. 1-86.

SPURR, J. E., and Goodrich, H. B. Geology of the Yukon gold district, Alaska, by Josiah Edward Spurr; with an introductory chapter on the history and condition of the district to 1897, by Harold Beach Goodrich. In Eighteenth Ann. Rept., pt. 3, 1898, pp. 87-392.

WALCoTt, C. D., Director. Account of operations in Alaska in 1898. In Nineteenth Ann. Rept., pt. 1, 1898, pp. 20, 53, 116-117. (Out of stock.)

Map of Alaska, showing known gold-bearing rocks, with descriptive text containing sketches of the geography, geology, and gold deposits and routes to the gold fields. Prepared in accordance with Public Resolution No. 3 of the Fifty-fifth Congress, second session, approved January 20, 1898. Printed in the engraving and printing division of the United States Geological Survey, Washington, D. C., 1898.44 pp., 1 map. A special publication. The data were brought together by S. F. Emmons, aided by W. H. Dall and F. C. Schrader. (Out of stock.)

1899.

WALCOTT, C. D., Director. Account of operations in Alaska in 1898-99. In Twentieth Ann. Rept., pt. 1, 1899, pp. 12, 52-53, 97, 126-134. (Out of stock.)

Maps and descriptions of routes of exploration in Alaska in 1898, with general information concerning the Territory. (Ten maps in accompanying envelope.) Prepared in accordance with Public Resolution No. 25 of the Fifty-fifth Congress, third session, approved March 1, 1899. Printed in the engraving and printing division of the United States Geological Survey, Washington, D. C., 1899. 138 pp., 10 maps in accompanying envelope. A special publication. Contributors: G. H. Eldridge, Robert Muldrow, J. E. Spurr, W. S. Post, W. C. Mendenhall, F. C. Schrader, W. J. Peters, A. H. Brooks, and E. C. Barnard. (Out of stock.) 
1900.

BAKER, Marcus. Alaskan geographic names. In Twenty-first Ann. Rept., pt. 2, 1900, pp. 487-509.

Brooks, A. H. A reconnaissance from Pyramid Harbor to Eagle City, Alaska, including a description of the copper deposits of the upper White and Tanana rivers. In Twenty-first Ann. Rept., pt. 2, 1900, pp. 331-391.

A reconnaissance in the Tanana and White River basins, Alaska, in 1898. In Twentieth Ann. Rept., pt. 7, 1900, pp. 425-494. (Out of stock.)

Eldridge, G. H. A reconnaissance in the Sushitna basin and adjacent territory, Alaska, in 1898. In Twentieth Ann. Rept., pt. 7, 1900, pp. 1-29.

Gannetr, Henry. Altitudes in Alaska. Bull. No. 169, 1900, 13 pp.

Mendenhald, W. C. A reconnaissance from Resurrection Bay to the Tanana River, Alaska, in 1898. In Twentieth Ann. Rept., pt. 7, 1900, pp. 265-340.

Rohn, Oscar. A reconnaissance of the Chitina River and the Skolai Mountains, Alaska. In Twenty-first Ann. Rept., pt. 2,1900, pp. 303-340. (Out of stock.)

Schrader, F. C. A reconnaissance of a part of Prince William Sound and the Copper River district, Alaska, in 1898. In Twentieth Ann. Rept., pt. 7, 1900, pp. 341-423. (Out of stock.) rivers, Alaska, in 1899. In Twenty-first Ann. Rept., pt. 2, 1900, pp. 441-486.

and Brooks, A. H. Preliminary report on the Cape Nome gold region, Alaska, with maps and illustrations. Washington, Government Printing Office, 1900.56 pp., 3 maps, and 19 pls. A special publication.

SpUrR, J. E. A reconnaissance in southwestern Alaska in 1898. In Twentieth Ann. Rept., pt. 7, 1900, pp. 31-264.

W ALCOTT, C. D., Director. Account of operations in Alaska in 1899-1900. In Twentyfirst Ann. Rept., pt. 1, 1900, pp. 17-18, 86, 145-149.

\section{1.}

Brooks, A. H. An occurrence of stream tin in the York region, Alaska. In Mineral Resources of the U. S. for 1900, 1901, pp. 267-271. Published also as a separate. Washington, Government Printing Office, 1901, cover and pp. 1-5.

The coal resources of Alaska. In Twenty-second Ann. Rept., pt. 3, 1901, pp. 515-571.

Richardson, G. B., and Collier, A. J. A reconnaissance of the Cape Nome and adjacent gold fields of Seward Peninsula, Alaska, in 1900. In a special publication entitled "Reconnaissances in the Cape Nome and Norton Bay regions, Alaska, in 1900." Washington, Government Printing Office, 1901, pp. $1-180$.

Mendentall, W. C. A reconnaissance in the Norton Bay region, Alaska, in 1900. In a special publication entitled "Reconnaissances in the Cape Nome and Norton Bay regions, Alaska, in 1900." Washington, Government Printing Office, 1901, pp. 181-218.

SCHRADER, F. C., and SPENCER, A. C. The geology and mineral resources of a portion of the Copper River district, Alaska. A special publication. Washington, Government Printing Office, 1901, pp. 1-94.

W ALcotr, C. D., Director. Account of operations in Alaska in 1900-1901. In Twentysecond Ann. Rept., pt. 1, 1901, pp. 35, 95-99, 144, 166-170.

1902.

BRooks, A. H. Preliminary report on the Ketchikan mining district, Alaska, with an introductory sketch of the geology of southeastern Alaska. Prof. Paper No. 1, 1902, pp. 1-120.

Collier, A.J. A reconnaissance of the northwestern portion of Seward Peninsula, Alaska. Prof. Paper No. 2, 1902, pp. 1-70.

Mendenhall, W. C. A reconnaissance from Fort Hamlin to Kotzebue Sound, Alaska, by way of Dall, Kanuti, Allen, and Kowak rivers. Prof. Paper No. 10,1902 , pp. 1-68.

WALCOTT, C. D., Director. Account of operations in Aiaska in 1901-2. In Twentythird Ann. Rept., 1902, pp. 20, 21, 57, 71-82, 161.

1903.

BAKER, MARCUS. Geographic dictionary of Alaska. Bull. No. 187, 1902, pp. 1-446. Brooks, A. H. Placer gold mining in Alaska in 1902. In Bull. No. 213, 1903, pp. 41-48. (Out of stock.)

Stream tin in Alaska. In Bull. No. 213, 1903, pp. 92-93. (Out of stock.)

13070-Bull. $327-07-6$ 
Collier, A. J. Coal resources of the Yukon basin, Alaska. In Bull. No. 213, 1903, pp. 276-283. (Out of 'stock.)

The coal resources of the Yukon, Alaska. Bull. No. 218, 1903, pp. 1-71.

The Glenn Creek gold mining district, Alaska. In Bull: No. 213, 1903, pp. 49-56. (Out of stock.)

Mendenhall, W. C. The Chistochina gold field, Alaska. In Bull. No. 213, 1903, pp. 71-75. (Out of stock.)

and ScHRADER, F. C. Copper deposits of Mount Wrangell region, Alaska. In Bull. No. 213, 1903, pp. 141-148. (Out of stock.).

The mineral resources of the Mount Wrangell district, Alaska. Prof. Paper No. 15,1903 , pp. 1-71.

W ALcotr, C. D., Director. Account of operations in Alaska in 1902-3. In Twentyfourth Ann. Rept., 1903, pp. 78-107, 167, 256.

1904.

Brooks, A. H. Placer gold mining in Alaska in 1903 . In Bull. No. 225, 1904, pp. 43-59.

Collier, A. J. Tin deposits of the York region, Alaska. In Bull. No. 225, 1904, pp. 154-167.

Tin deposits of the York region, Alaska. Bull. No. 229.

Martin, G. C. Petroleum fields of Alaska and the Bering River coal field. In Bull. No. 225,1904, pp. $365-382$.

Mofrit, F. H. The Kotzebue placer gold field of Seward Peninsula, Alaska. In Bull. No. 225, 1904, pp. 74-80.

Prinde, L. M. Gold placers of the Fairbanks district, Alaska. In Bull. No. 225, 1904, pp. 64-73.

Schrader, F. C., and PeTers, W. J. A reconnaissance in northern Alaska, across the Rocky Mountains, along the Koyukuk, John, Anaktuvuk, and Colville rivers, and the Arctic coast to Cape Lisburne, in 1901. Prof. Paper No. 20, 1904, pp. 1-139.

Spencèr, A. C. The Juneau gold belt, Alaska. In Bull. No. 225, 1904, pp. 28-42.

W. Alcotт, C. D., Director. Account of operations in Alaska in 1903-4. In Twentyfifth Ann. Rept., 1904, pp. 68-85, 346, 348, 352, 354.

Wright, C. W. The Porcupine placer mining diștrict, Alaska. In Bull. No. 225, 1904 , pp. 60-63.

The Porcupine placer district, Alaska. Bull. No. 236, 1904, pp. 1-35.

1905.

Brooks, A. H. Administrative report. In Report on progress of investigations of mineral resources of Alaska in 1904: Bull. U. S. Geol. Survey No. 259, 1905, pp. 13-17.

Placer mining in Alaska in 1904 . In Bull. No. 259, 1905, pp. 18-31.

Collter, A. J. Coal fields of the Cape Lisburne region. . In Bull. No. 259, 1905, pp. 172-185.

Gold mine on Unalaska Island. In Bull. No. 259, 1905, pp. 102-103. 120-127:

MARTIN; G. C. Bering River coal field. In Bull. No. 259, 1905, pp. 140-150.

Cape Yaktag placers. In Bull. No. 259, 1905, pp. 88-89.

- Notes on the petroleum fields of Alaska. In Bull. No. 259, 1905, pp. 128-139.

The petroleum fields of the Pacific coast of Alaska, with an account of the Bering River coal deposits. Bull. No. 250, 1905, pp. 1-64.

Mendenhall, W. C. Geology of the central Copper River region, Alagka. Prof. Paper No. 41, 1905, pp. 1-133.

Mofrit, F. H. Gold placers of Turnagain Arm, Cook Inlet. In Bull. No. 259, 1905, pp. 90-99.

The Fairhaven gold placers of Seward Peninsula. Bull. No. 247, pp. 1-85.

PRINDLE, L. M. The gold placers of the Fortymile, Birch Creek, and Fairbanks regions. Bull: No. 251,1905 , pp. 1-89.

and Hess, F. L. Rampart placer region. In Bull. No. 259, 1905, pp. 104 119.

Purington, C. W. Methods and costs of gravel and placer mining in Alaska. Bull. No. 263, 1905, pp. 1-362. Also in Bull. No. 259, 1905, pp. 32-46.

Spencer, A. C. The Treadwell ore deposits. In Bull. No. 259, 1905, pp. 69-87.

STONE, R. W. Coal resources of southwestern Alaska. In Bull. No. 259, 1905, pp. 151-171. 
WalcotT, C. D., Director. Account of operations in Alaska in 1904-5. In Twentysixth Ann. Rept., 1905, pp. 73-80.

WRIGHT, F. E. and C. W. Econonic developments in southeastern Alaska. In Bull. No. 259, 1905, pp. 47-68.

1906.

BAKer, M., and McCormick, J. C. Geographic dictionary of Alaska, second edition. Bull. No. 299, 1906, pp. 1-690.

Brooks, A. H. The geography and geology of Alaska, a summary of existing knowledge, with a section on climate, by Cleveland Abbe, jr., and a topographic map and description thereof, by R. U. Goode. Prof. Paper No. 45, 1906, pp. $1-327$.

Administrative report. In Report on progress of investigations of mineral resources of Alaska in 1905: Bull. U. S. Geol. Survey No. 284, 1906, pp. 1-3.

The mining industry in 1905 . In Bull. No. 284,1906, pp. 4-9.

Railvay routes. In Bull. No. 284, 1906, pp. 10-17.
Colliter, A.J. Geology and coal resources of Cape Lisburne region, Alaska. Bull. No. 278,1906 , pp. $1-54$.

Grant, U. S. Copper and other mineral resources of Prince William Sound. In Bull. No. 284, 1906, pp. 78-87.

Hess, F. I. The York tin region. In Bull. No. 28t, 1906, pp. 145-157.

MarTin, G. C. Markets for Alaska coal. In Bull. No. 284, 1906, pp. 18-27.

- Distribution and character of the Bering River coal. In Bull. No. 284, 1906, pp. 65-76.

Preliminary statement on the Matanuska coal field. In Bull. No. 284, 1906, pp. 88-100.

Reconnaissance of the Matanuska coal field, Alaska, in 1905. Bull. No. 289, 1906 , pp. $1-36$.

Moffit, F. H. Gold mining on Seward Peninsula. In Bull. No. 284, 1906, pp. 132 141 .

and Stone, R. W. Mineral resources of the Kenai Peninsula; Gold fields of the Turnagain Arm region, by F. H. Moffit, pp. 1-52; Coal fields of the Kachemak Bay region, by R. W. Stone, pp. 53-73. Bull. No. 277, 1906, pp. 1-80.

PAige, SinNeY. The Herendeen Bay coal field. In Bull. No. 284, 1906, pp. 101-108.

Prindele, L. M. Yukon placer fields. In Bull. No. 284, 1906, pp. 109-127.

The Yukon-Tanana region, Alaska; description of Cirele quadrangle. Bull. No. 295,1906 , pp. 1-27.

and Hrss, F. L. The Rampart gold placer region, Alaska. Bull. No. 280, 1906, pp. $1-54$.

Spencer, A. C., and Wright, C. W. The Juneau gold belt, Alaska, by A. C. Spencer, pp. 1-137; and A reconnaissance of Admiralty Island, Alaska, by C. W' Wright, pp. 138-154. Bull. No. 287, 1906, pp. 1-161.

Stone, R. W. Reconnaissance from Circle to Fort Hamlin. In Bull. No. 284, 1906, pp. 128-131.

TARR, R. S. The Yakutat Bay region. In Bull. No. 284, 1906, pp. 61-64.

WALCOT, C. D., Director. Account of operations in Alaska in 1905-6. In Twentyseventh Ann. Rept., 1906, pp. 25-27.

Wright, C. W. Nonmetallic deposits of southeastern Alaska. In Bull. No. 284, 1906, pp. 55-60.

WrIGHT, F. E. and C. W. Lode mining in southeastern Alaska. In Bull. No. 284, 1906, pp. 30-53.

\section{7.}

Blackwelder, Eljot. Reconnaissance on the Pacific coast from Yakutat to Alsek River. In Bull. No. 31t, 1907, pp. 82-88.

Bвоокs, A. H. Administrative report: In Report on progress of investigations of mineral resources of Alaska in 1906: Bull. U. S. Geol. Survey No. 314,

1907, pp. 11-18.
The mining industry in 1906 . In Bull. No. 314, 1907, pp. 19-39.

The Kougarok region. In Bull. No. 314, 1907, pp. 164-181.

The Circle precinct. In Bull. No. 314, 1907, pp. 187-204.

Hoyt, J. C., and Hense. w, F. F. Water supply of Nome region, Seward Peninsula, Alaska, 1906. Water-Supply Paper Ňo. 196, 1907, pp. 1-52.

Water supply of Nome region, Seward Peninsula, 1906. In Bull. No. 314,1907 , pp. $182-186$.

Marinis, G. C. The Alaska coal fields. In Bull. No. 314, 1907, pp. 40-46.

Petroleum at Controller Bay. In Bull. No. 314, 1907, pp. 89-103. 
Moffit, F. H. The Nome region. . In Bull. 314, 1907, pp. 126-145.

PAIGE, S., and KNOPF, A. Geologic reconnaissance in the Matanuska and Talkeetna basins. Bull. No. 327, 1907, pp. 1-71.

Reconnaissance in the Matanuska and Talkeetna basins. In Bull. No. 314, 1907, pp. 104-125.

Prindle, L. M. The Bonnifield and Kantishna regions. In Bull. No. 314, 1907, pp. 205-226.

Smrth, P. S. Gold fields of the Solomon and Niukluk river basins. In Bull. No. 314,1907 , pp. 146-156.

Geology and mineral resources of Iron Creek. In Bull. No. 314, 1907, pp. 157-163.

Wright, C. W. Lode mining in southeastern Alaska. In Bull. No. 314, 1907, pp. 47-72.

Nonmetalliferous mineral resources of southeastern Alaska. In Bull. No. 314, 1907, pp. 73-81.

\section{Papers on Alaska in Preparation.}

Brooks, A. H., and Prindle, L. M. An exploration in the Mount McKinley region. Collier, A. J., Hess, F. L., and Brooks, A. H. The gold placers of a part of the Seward Peninsula, Alaska. Bull. No. 328, 1907, pp. 1-

Grant, U. S. The geology and mineral resources of the Prince William Sound region.

Martin, G. C. Geology and mineral resources of Controller Bay region.

Mofrit, F. H. The Chitina copper belt.

- Hess, F. L., and Smith, P. S. Geology of the area represented on the Nome and Grand Central special maps.

Prindle, L. M. The Yukon-Tanana region, Alaska; description of the Fairbanks and Rampart quadrangles.

Sмrтн, P. S. Geology and. mineral resources of the areas represented by the Solomon and Casadepaga quadrangles.

TARR, R. S. Geologic reconnaissance of the Yakutat Bay region.

Wright, F. E. and C. W. Mineral resources of the Wrangell and Ketchikan mining districts, Alaska.

\section{Topographic Maps of Alaska.}

The following maps are for sale at 5 cents a copy, or $\$ 3$ per hundred:

Casadepaga quadrangle, Seward Peninsula; scale, 1:62500. T. G. Gerdine.

Fortymile quadrangle; scale, 1:250000. E. C. Barnárd.

Grand Central Special, Seward Peninsula; scale, 1:62500. T. G. Gerdine.

Juneau Special quadrangle; scale, 1:62500. W. J. Peters.

Nome Special, Seward Peninsula; scale, 1:62500. T. G. Gerdine.

Solomon Special, Seward Peninsula; scale, 1:62500. T. G. Gerdine.

The following maps are for sale at 15 cents a copy, or $\$ 9$ per hundred:

Reconnaissance map of southern part of Seward Peninsula; scale, 1:250000. E. C. Barnard and T. G. Gerdine.

Reconnaissance map of northwestern part of Seward Peninsula; scale, 1:250000. T. G. Gerdine and D. C. Witherspoon.

Reconnaissance map of northeastern part of Seward Peninsula; scale, 1:250000. D. C. Witherspoon.

The following maps are included as illustrations of published reports, but have not been issued separately. They can be obtained only by securing the report.

Alaska, topographic map of; scale, 1:2500000. Preliminary edition. Contained in "The geography and geology of Alaska, a summary of existing knowledge, etc." Prof. Paper No. 45 . R. U. Goode.

Cape Nome and adjacent.gold fields; scale, 1:250000. Contained in a special publication of the United States Geological Survey, entitled "Reconnaissances in the Cape Nome and Norton Bay regions, Alaska," 1900. Washington. Government Printing Office, 1901. E. C. Barnard.

Chitina and lower Copper River region; scale, 1: 250000. Contained in a special publication of the United States Geological Survey, entitled "The geology and mineral resources of a portion of the Copper River district, Alaska." Washington. Government Printing Office, 1901. T. G. Gerdine and D. C. Witherspoon.

Circle quadrangle, Yukon-Tanana region; scale, 1:250000. Contained in "The YukonTanana region, Alaska; description of Circle quadrangle." Bull. No. 295. D. C. Witherspoon. 
Cook Inlet, head of, to the Tanana via Matanuska and Delta rivers, also part of Kenai Peninsula; scale, 1:625000. Contained in "A reconnaissance from Resurrection Bay to Tanana River, Alaska, in 1898." Twentieth Ann. Rept., pt. 7, 1900 , pp. 265-340. IV. C. Mendenhall.

Cook Inlet, region from head of, to Kuskokwim River and down the Kuskokwim to Bering Sea, Bristol Bay, and a part of Alaska Peninsula; scale 1:625000. Published in sections in "A reconnaissance in southwestern Alaska, in 1898." Twentieth Ann. Rept., pt. 7, 1900, pp. 31-26t. W. S. Post.

Cook Inlet placer fields; scale 1:250000. Contained in "Mineral Resources of Kenai Peninsula, Alaska." Bull. No. 277. E. G. Hamilton.

Copper and upper Chistochina rivers; scale, 1:250000. Contained in "Geology of the central Copper River region, Alaska." Prof. Paper No. 41. T. G. Gerdine.

Copper, Nabesna, and Chisana rivers, headwaters of; scale, 1:250000. Contained in "Geology of the central Copper River region, Alaska." Prof. Paper No. 41. D. C. IVitherspoon.

Copper River region; scale, 1:376000. Contained in "A reconnaissance of a part of Prince William Sound and the Copper River district, Alaska, in 1898." Twentieth Ann. Rept., pt. 7, 1900, pp. 341-423. P. G. Lowe, Emil Mahlo, and F. C. Schrader. (Out of stock.)

Fairbanks and Birch Creek districts, reconnaissance maps of; scale, 1:250000. Contained in "The gold placers of the Fortymile, Birch Creek, and Fairbanks regions." Bull. No. 251, 1905. T. G. Gerdine.

Fort Yukon to Kotzebue Sound, reconnaissance map of; scale, 1:625000. Contained in "Reconnaissance from Fort Hamlin to Kotzebue Sound, Alaska, by way of Dall, Kanuti, Allen, and Kowak rivers." Prof. Paper No. 10, 1902. D. L. Reaburn.

Koyukuk River to month of Colville River, including John River; scale, 1:625000. Contained in "A reconnaissance in northern Alaska across the Rocky Mountains, along Koyukuk, John, Anaktuvuk, and Colville rivers, and the Arctic coast to Cape lisburne, in 1901." Prof. Paper No. 20. IV. J. Peters.

Koyukuk and Chandlar rivers, portions of; scale, 1:625000. Contained in "Preliminary report of a reconnaissance along the Chandlar and Koyukuk rivers, Alaska, in 1899." Twenty-first Ann. Rept., pt. 2, 1900. 'T. G. Gerdine.

Lynn canal, routes from, via headwaters of White and Tanana rivers to Eagle City; scale, 1:625000. Contained in "A reconnaissance from Pyramid Harbor to Eagle City, Alaska." 'Twenty-first Ann. Rept., pt. 2, 1900, pp. 331-391. W. J. Peters.

Mount McKinley region; scale, 1:625000. Contained in "The geography and geology of Alaska, a summary of existing knowledge, etc." Prof. Paper No. 45. D. L. Reaburn.

Norton Bay region; scale, 1:625000. Contained in a special publication of the United States Geological Survey, entitled " Reconnaissances in the Cape Nome and Norton Bay regions, Alaska, in 1900." Washington. Government Printing Office, 1901. W. J. Peters.

Porcupine placer region; scale, 1 inch $=31$ miles. Contained in "The Porcupine. placer district, Alaska." Bull. No. 236. C. W. Wright.

Prince William Sound, sketch map of; scale 1:376000. Contained in a special publication of the United States Geological Survey, entitled "The geology and mineral resources of a portion of the Copper River district, Alaska." Washington. Government Printing Office, 1901. Emil Mahlo and F. C. Schrader.

Seward Peninsula, northeastern portion of, topographic reconnaissance of; scale, $1: 250000$. Contained in "The Fairhaven gold placers, Seward Peninsula, Alaska." Bull. No. 247, 1905. D. C. Witherspoon.

Seward Peninsula, northwestern part of; scale, $1: 250000$. Contained in "A reconnaissance of the northwestern portion of Seward Peninsula, Alaska." Prof. Paper No. 2, 1902. T. G. Gerdine.

Sushitna River and adjacent territory; scale, 1:625000. Contained in "A reconnaissance in the Sushitna basin and adjacent territory, Alaska, in 1898." Twentieth Ann. Rept., pt. 7, 1900, pp. 1-29. Robert Mnldrow.

Tanana and White rivers, portions of; scale, 1:625000. Contained in "A reconnaissance in the Tanana and White River basins, Alaska, in 1898." Twentieth Ann. Rept., pt. 7, 1900, pp. 425-494. WV. J. Peters.

York region; scale, 1:250000. Containerl in "The tin deposits of the York region, 'Alaska." Bull. No. 222. T. G. Gerdine. 
York and Kugruk regions, sketch maps of. Contained in a special publication of the United States Geological Survey, entitled "Reconnaissances in Cape Nome and Norton Bay regions, Alaska, in 1900." Washington. Government Printing Office, 1901. A. H. Brooks.

Yukon-Tanana region, reconnaissance map of; scale, 1:625000. Contained in "The gold placers of the Fortymile, Birch Creek, and Fairbanks regions, Alaska." Bull. No. 251. T. G. Gerdine.

Topographic Maps of Alaska in Preparation.

Berners Bay Special; scale, 1:62500. R. B. Oliver.

Chitina quadrangle; scale, 1:250000. T. G. Gerdine and D. C. Witherspoon.

Controller Bay region Special; scale, 1:62500. E. (i. Hamilton.

Fairbanks Special; scale, 1:62500. T. G. Gerdine and R. H. Sargent.

Fairbanks quadrangle; scale, 1:250000. D. C. Witherspoon.

Kasaan Peninsula Special; scale, 1:62500. D. C. Witherspoon and J. W. Bagley.

Rampart quadrangle; scale, 1:250000. D. C. Witherspoon.

Reconnaissance map of Matanuska River region; scale, 1:250000. T. G. Gerdine and R. H. Sargent. 

